\title{
Archaeological and Historical Investigations at the Site of the New Bexar County Justice Center in Downtown San Antonio, Texas
}

Anne A. Fox

I. Waynne Cox

Lynn Highley

David Hafernik

Follow this and additional works at: https://scholarworks.sfasu.edu/ita

Part of the American Material Culture Commons, Archaeological Anthropology Commons, Environmental Studies Commons, Other American Studies Commons, Other Arts and Humanities Commons, Other History of Art, Architecture, and Archaeology Commons, and the United States History Commons

Tell us how this article helped you.

This Article is brought to you for free and open access by the Center for Regional Heritage Research at SFA ScholarWorks. It has been accepted for inclusion in Index of Texas Archaeology: Open Access Gray Literature from the Lone Star State by an authorized editor of SFA ScholarWorks. For more information, please contact cdsscholarworks@sfasu.edu. 


\section{Archaeological and Historical Investigations at the Site of the New Bexar County Justice Center in Downtown San Antonio, Texas}

\section{Creative Commons License}

\section{(c) (1) \&}

This work is licensed under a Creative Commons Attribution-NonCommercial 4.0 International License 


\section{ARCHAEOLOGICAL AND HISTORICAL INVESTIGATIONS AT THE SITE OF THE NEW BEX AR COUNTY JUSTICE CENTER IN DOWNTOWN SAN A NTONIO, TEXAS}

Anne A. Fox, I. Waynne Cox, Lynn Highley, and Dayid Hafernik With a Contribution by Robert Harrison

Center for Archaeological Research The University of Texas at San Aitonlo Archaeologlcal Survey Report, No. 184 





\section{ARCHAEOLOGICAL AND HISTORICAL INVESTIGATIONS AT THE SITE OF THE NEW BEXAR COUNTY JUSTICE CENTER IN DOWNTOWN SAN ANTONIO, TEXAS}

\section{Anne A. Fox, I. Waynne Cox, Lynn Highley, and David Hafernik With a Contribution by Robert Harrison}

Texas Antiquities Committee Permits No. 190 and No. 564

Center for Archaeological Research The University of Texas at San Antonio ${ }^{\circledR}$ Archaeological Survey Report, No. 184 
The following information is provided in accordance with General Rules of Practice and Procedure, Chapter 41.11 (Investigative Reports), Texas Antiquities Committee:

1. Type of investigation: archaeological testing;

2. Project name: Bexar County Justice Center;

3. County: Bexar;

4. Principal investigator: Thomas R. Hester; coprincipal investigator: Jack D. Eaton; coprincipal investigator and project director: Anne A. Fox;

5. Name and location of sponsoring agency: Bexar County Commissioners Court, San Antonio, Texas;

6. Texas Antiquities Committee Permits No. 190 and No. 564;

7. Published by the Center for Archaeological Research, The University of Texas at San Antonio, Texas 78285-0658, 1989.

A list of publications offered by the Center for Archaeological Research can be obtained by sending $\$ 1.00$ to the Center for Archaeological Research, The University of Texas at San Antonio, San Antonio, Texas 78285-0658. 


\begin{abstract}
Between 1978 and 1987, archaeologists from the Center for Archaeological Research of The University of Texas at San Antonio conducted test excavations and monitored demolition of buildings on NCB 100 within the Main and Military Plazas National Historic District in downtown San Antonio. The block is the site chosen for construction of a Bexar County Justice Center. The sites of three small residences on the south end of the block were tested. Of these, two were thought to be eligible for nomination to the National Register of Historic Places and for nomination as State Archeological Landmarks. At the north end of the block, the foundations of a small stone house built by the Salinas family were located, and testing was done in the back yard. A well believed built by the Salinas family was examined and recorded. A section of the San Pedro acequia, was exposed and recorded, and it is recommended that part of this waterway be restored during the landscaping for the new building.
\end{abstract}

In 1988, monitoring was done for excavation of a trench between the Bexar County Courthouse and the new Justice Center, which will provide a substreet walkway (tunnel) under Main Street. No significant cultural resources were encountered. 


\section{TABLE OF CONTENTS}

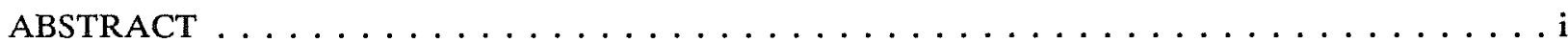

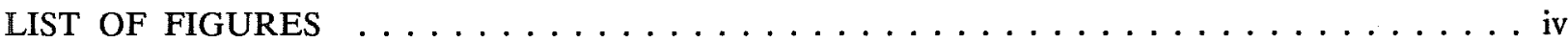

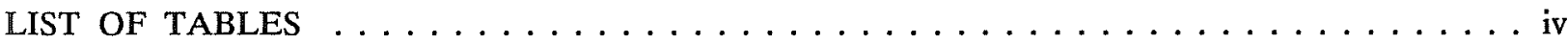

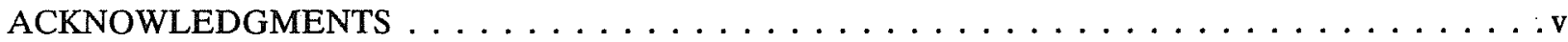

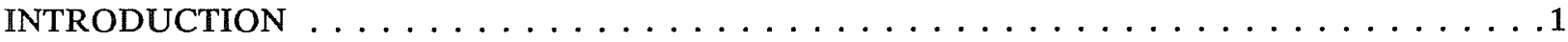
PREVIOUS INVESTIGATIONS IN THE AREA $\ldots \ldots \ldots \ldots \ldots \ldots \ldots \ldots \ldots \ldots \ldots \ldots$

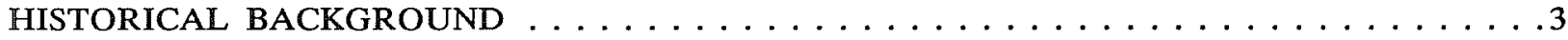

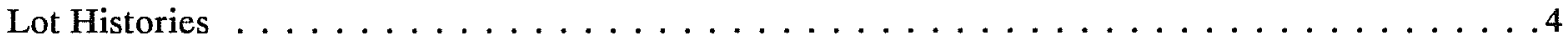

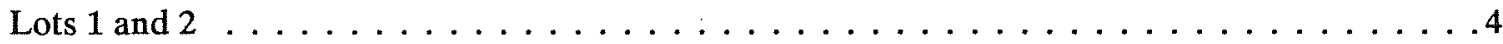

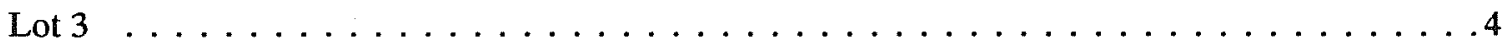

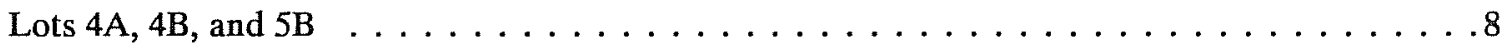

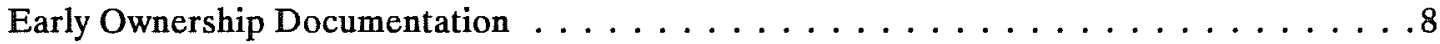

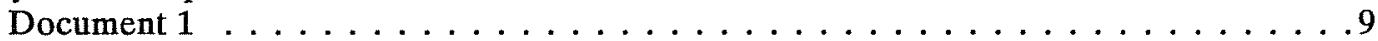

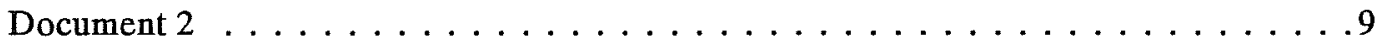

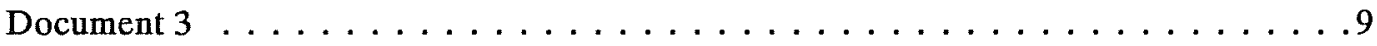

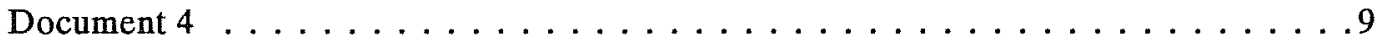

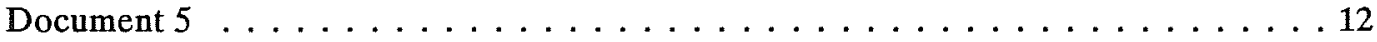

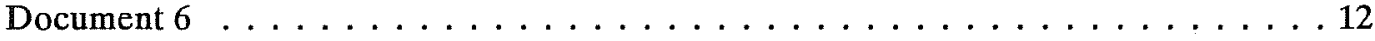

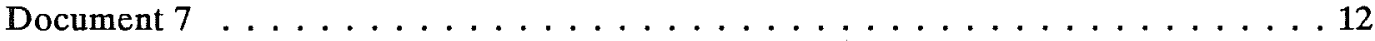

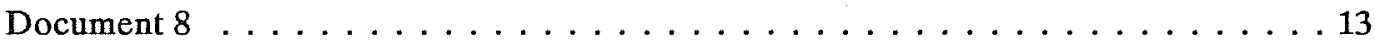

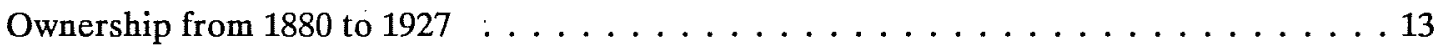

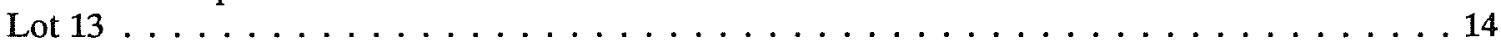

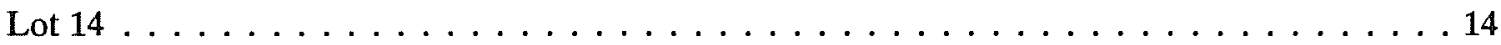

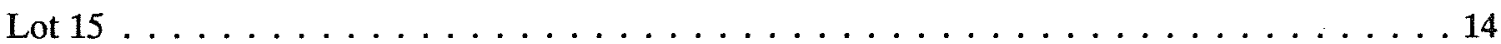

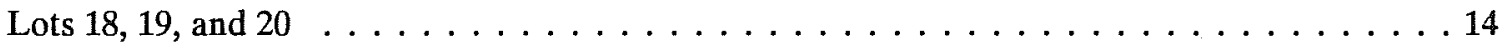

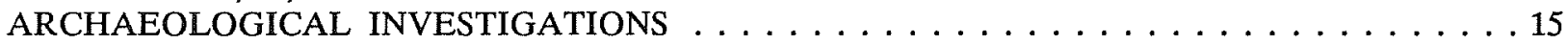

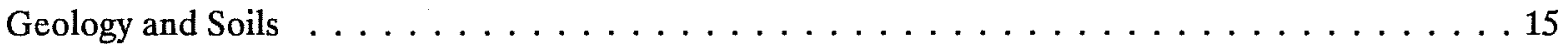

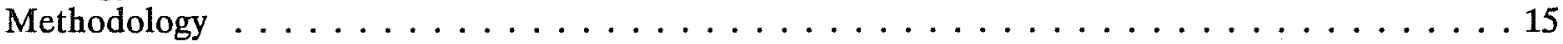

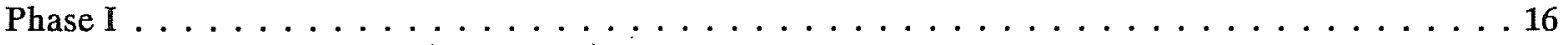

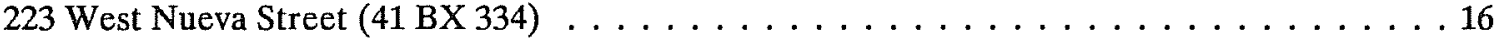

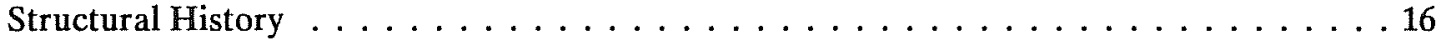

Archaeological Testing . . . . . . . . . . . . . . . . . . 16

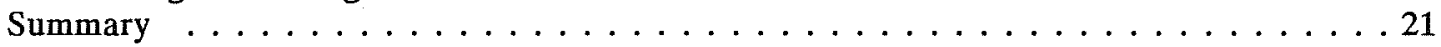

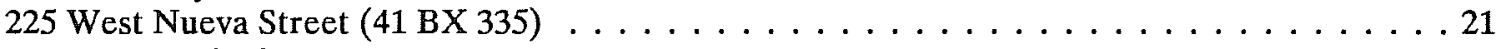

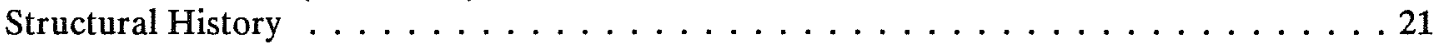

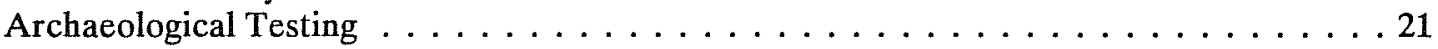

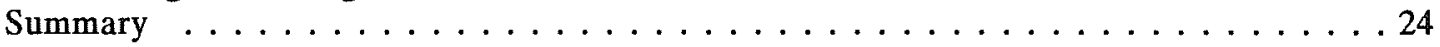

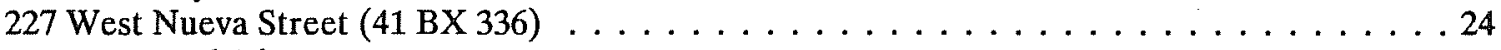

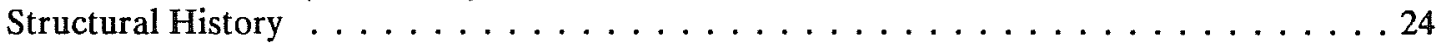

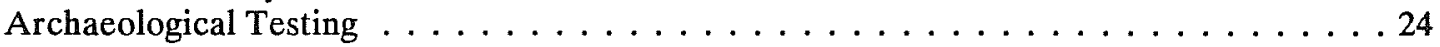

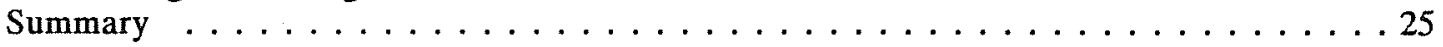

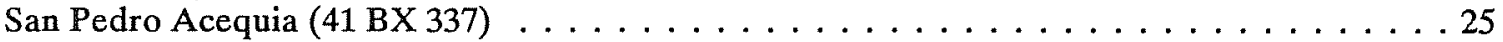

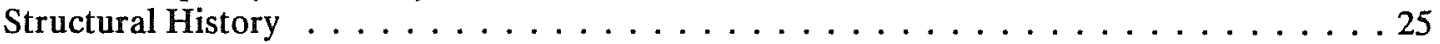

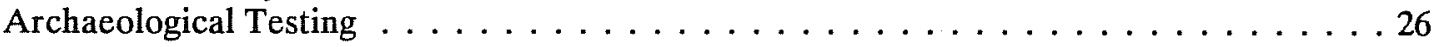

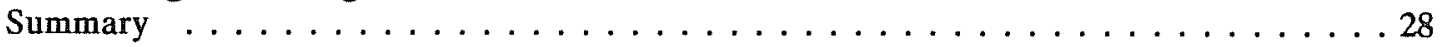

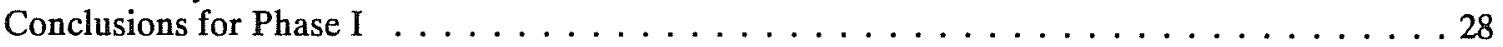

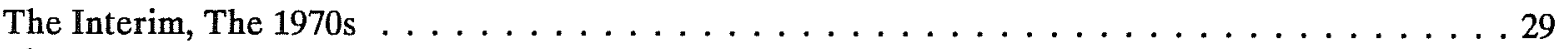

Phase II . . . . . . . . . . . . . . . . . . . . . . . 29

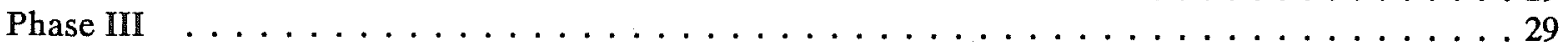

Trench A . . . . . . . . . . . . . . . . . . . . . 29

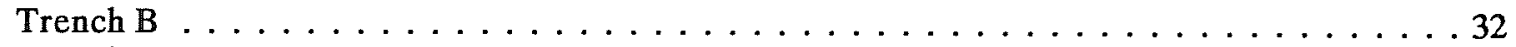

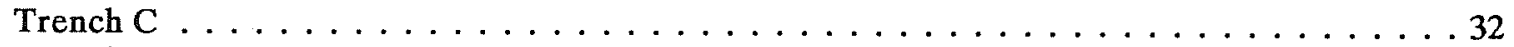

Trench D . . . . . . . . . . . . . . . . . . . . 34

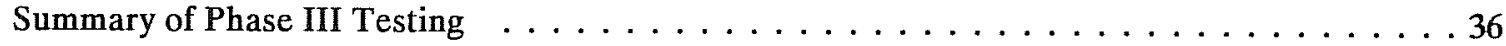


Recommendations for Further Work after Phase III $\ldots \ldots \ldots \ldots \ldots$

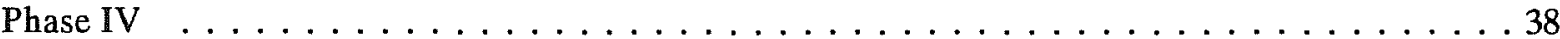

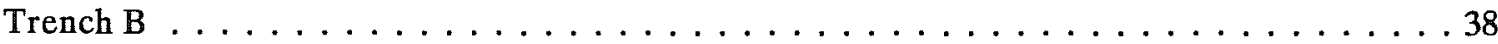

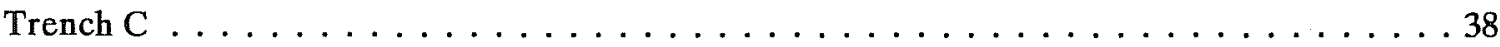

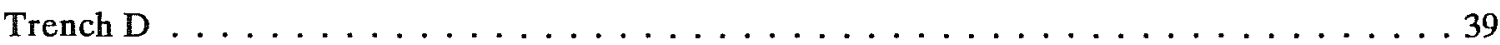

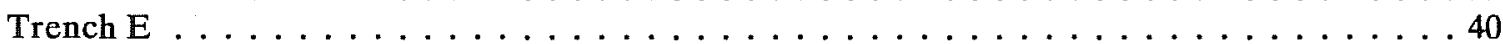

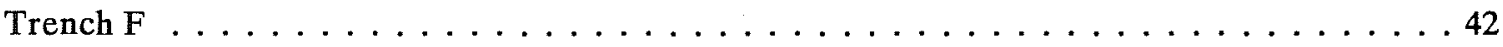

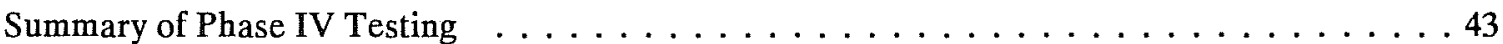

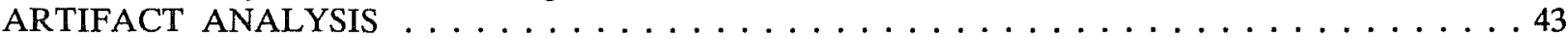

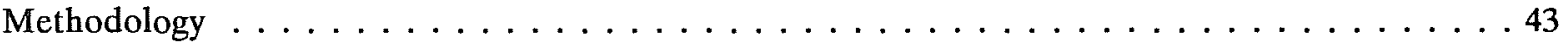

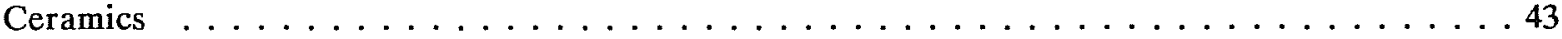

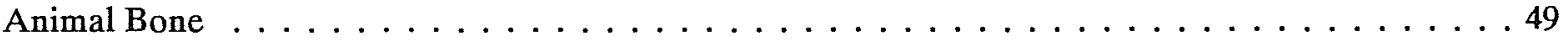

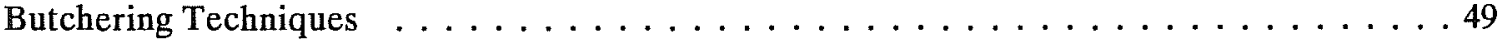

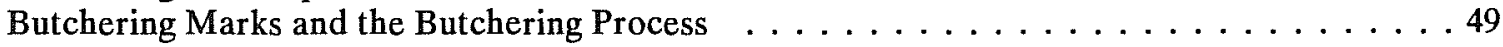

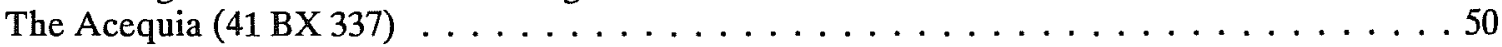

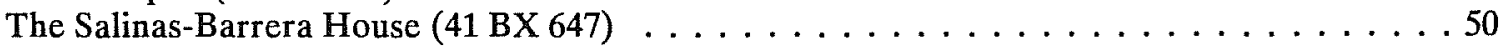

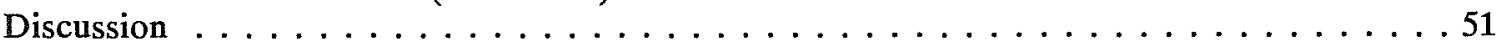

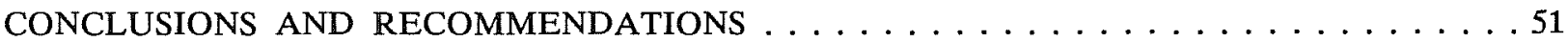

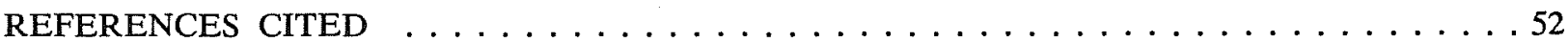

APPENDIX. MONITORING OF JUSTICE CENTER TUNNEL (I. Waynne Cox) $\ldots \ldots \ldots$. . . 58

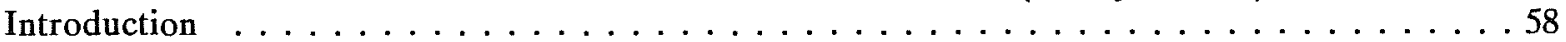

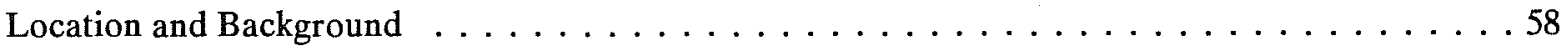

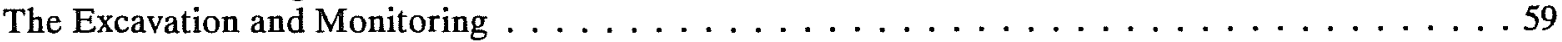

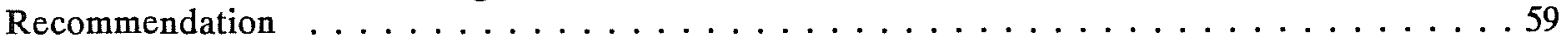

References Cited . . . . . . . . . . . . . . . . . . . . . . . 59 


\section{LIST OF FIGURES}

1. Project Area Location Within Downtown San Antonio $\ldots \ldots \ldots \ldots \ldots \ldots \ldots \ldots$

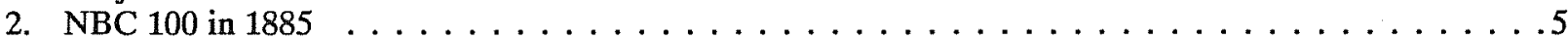

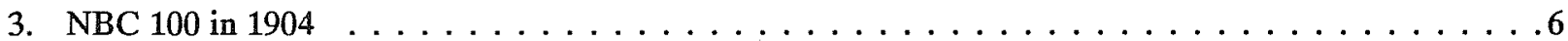

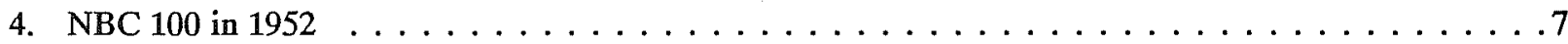

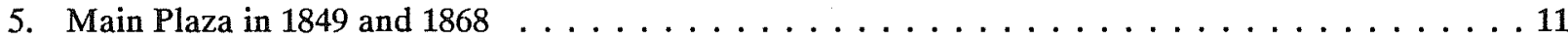

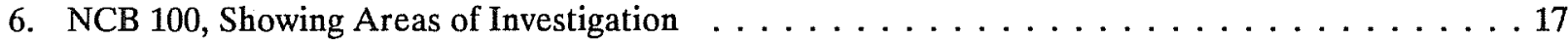

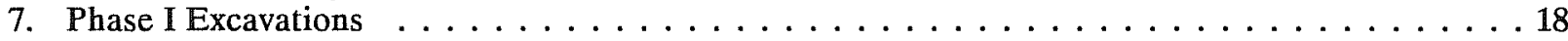

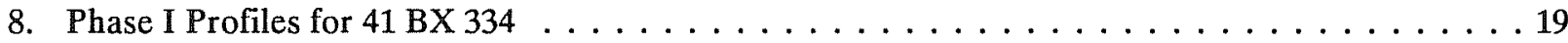

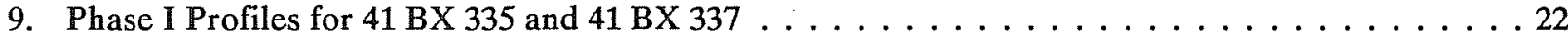

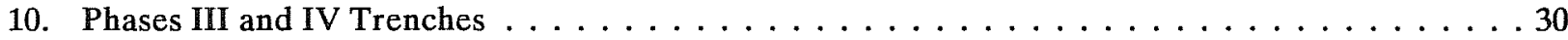

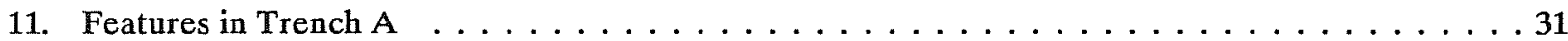

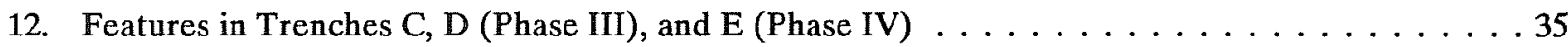

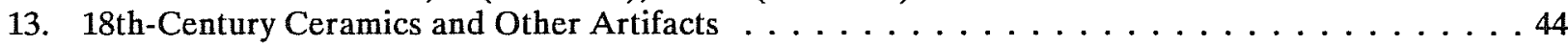

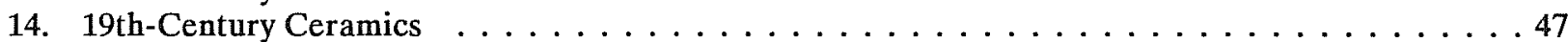

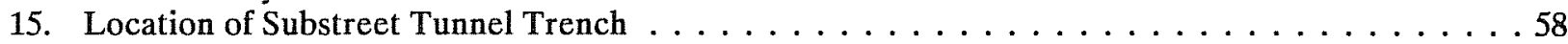

\section{LIST OF TABLES}

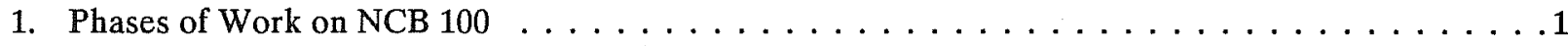

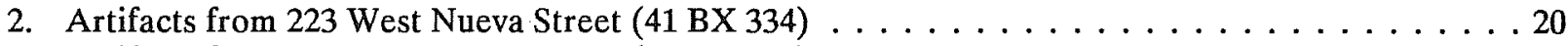

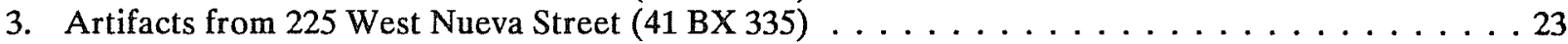

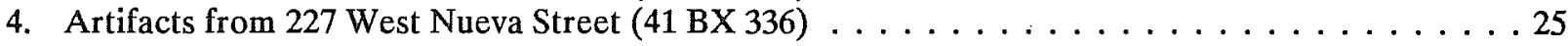

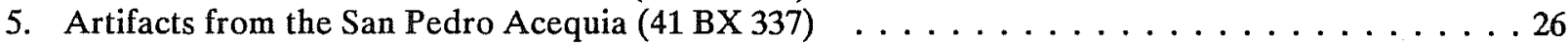

6. Types of Sherds and Maker's Marks from the San Pedro Acequia (41 BX 337) . . . . . . . . 28

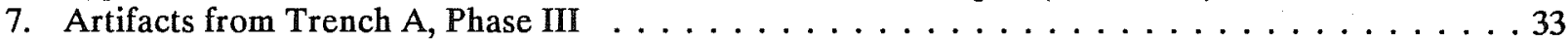

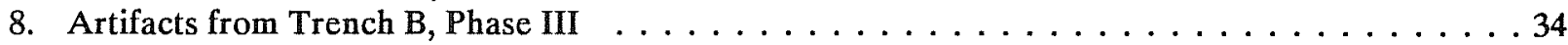

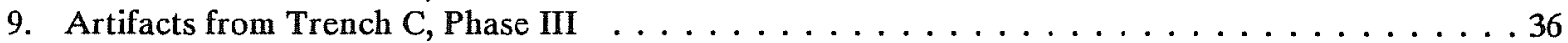

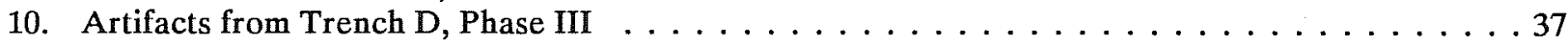

11. Artifacts from Trench B, Level 3, Phase IV . . . . . . . . . . . . . . . . . . 39

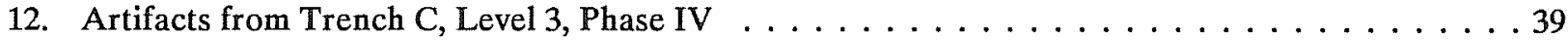

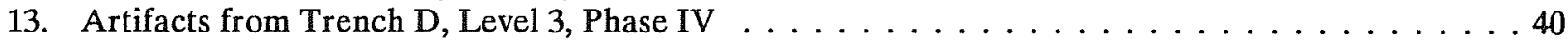

14. Artifacts from Trench $D$, Controlled Excavation, Phase IV . . . . . . . . . . . . . 41

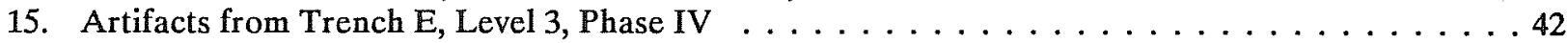

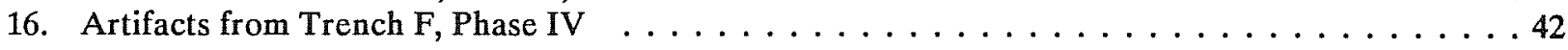




\section{ACKNOWLEDGMENTS}

We would like to express our appreciation to a number of people who have made this project possible. The late Judge A. J. Ploch and the members of Commissioners Court in 1978 understood the necessity for our work and financed the first season. Judge Tom Vickers and the members of the present Commissioners Court have supported our further work on the site and the publication of this report. Bexar County Director of Public Works, Robert L. Tomasini, and his staff have taken a personal interest in the project and expedited our work in many ways.

John Leal, county archivist, has provided numerous documents that have helped in reconstructing the history of the site. Also helpful in these matters have been the staff of the Daughters of the Republic of Texas Research Library at the Alamo. James Kallison provided details in the history of the Kallison store and memories of what the area looked like over the years. Angelina Salinas Fernandez has been most helpful in sharing her personal files on the Salinas family and their ownership of the house on the northeast corner of the block.

The following CAR employees and volunteers also merit our special thanks:

Phase I: James Ivey and Fred Valdez, Jr., archaeologists; Roberta McGregor, Carolyn Furman, and Joe Perez, volunteers.

Phase II: Harvey P. Smith, Jr., archaeologist.

Phase III: William B. Ellis, David Turner, Cathy Dodt-Ellis, Paul Maslyk, and Kelly Scott, archaeologists; Rochelle Leneave, Michael Marchbanks, Burnley Smith, Ann Stone, and Frances Meskill, volunteers.

Phase IV: William B. Ellis, Cathy Dodt-Ellis, Kenny Wright, Waynne Cox, and Paul Maslyk, archaeologists; Tommy Tomesal, Patty Hand, Burnley Smith, and Darla Cox, volunteers.

The illustrations for this report were drafted by David Hafernik, William B. Ellis, and Kenneth Brown. The research on the history of the Salinas-Barrera property was carried out by Lynn Highley, while James Ivey and Waynne Cox reconstructed the history of the rest of the block.

This project has been somewhat of a community effort. During the field work, numerous local citizens took a personal interest in what we were doing and volunteered interesting facts about the history of the area. People working in the courthouse and in other businesses in the vicinity came daily to the site to watch our progress. We hope this report will help to explain to everyone what we were doing and what we found. 



\section{INTRODUCTION}

During the period from 1978 to 1987, archaeological investigations and historical research were done for the Bexar County Commissioners Court by the Center for Archaeological Research (CAR), The University of Texas at San Antonio (UTSA). The subject of the research was New City Block (NCB) 100, the site chosen for construction of a 240,000-square-foot Justice Center. This block is located across the street from the Bexar County Courthouse, within the Main and Military Plazas National Historic District in downtown San Antonio (Fig. 1). This block is of primary historical importance as this area was part of the original town of San Antonio. The area is also one of the few remaining lots in the historic district that contains deposits below ground that have not been totally removed by construction of basements for commercial buildings.

The project has been done in compliance with Section 106 of the National Historic Preservation Act of 1966 (as amended) and Executive Order 11593. No federal funds were used in the project. Since the property belongs to Bexar County, Texas Antiquities Committee Permits No. 190 (1978) and No. 564 (1986) were issued for the various phases of the project. A preliminary report was submitted to Commissioners Court at the completion of work for Phases I and III (Fox 1978a; Ellis 1986), with the planned intention of compiling a final report to be published at the conclusion of the project. We have now completed archaeological investigations on areas of NCB 100 where archival research suggested that undisturbed cultural remains could be anticipated to survive. Present plans for the new Justice Center building include a paved parking area on the south or Nueva Street portion of the property. Since it has been our experience that asphalt paving is an excellent way to preserve archaeological remains, we are not recommending further archaeological investigations in this area now.

The work was divided into phases as shown in Table 1. Archaeology during Phases I, III, and IV was aided by the participation of UTSA students and members of the local community as volunteer helpers (indicated by + in Table 1 ). The personnel and machinery required to cut the asphalt paving and excavate the test trenches were provided by Bexar County. Principal investigator for the entire project was Thomas R. Hester, director of the Center for Archaeological Research, with Jack D. Eaton, associate director, as coprincipal investigator. Field work was done under the supervision of Anne A. Fox as a coprincipal investigator, except for the monitoring in Phase II which was done by Harvey P. Smith, Jr.

TABLE 1. PHASES OF WORK ON NCB 100

\begin{tabular}{|c|c|c|c|c|c|}
\hline Phase & Date & Location & Work Done & Man/Days & Sites Tested \\
\hline I & 1978 & $\begin{array}{l}\text { southern third } \\
\text { of block }\end{array}$ & 7 trenches & $15+$ & $\begin{array}{l}41 \text { BX } 334 \\
41 \text { BX } 335 \\
41 \text { BX } 336 \\
41 \text { BX } 337\end{array}$ \\
\hline II & 1979 & $\begin{array}{l}\text { northern half } \\
\text { of block }\end{array}$ & $\begin{array}{l}\text { monitoring } \\
\text { demolition }\end{array}$ & 3 & \\
\hline III & 1986 & $\begin{array}{l}\text { northeast } \\
\text { section }\end{array}$ & 4 trenches & $20+$ & $41 \mathrm{BX} 647$ \\
\hline IV & 1987 & $\begin{array}{l}\text { northeast } \\
\text { corner }\end{array}$ & 6 trenches & $15+$ & $41 \mathrm{BX} 647$ \\
\hline
\end{tabular}




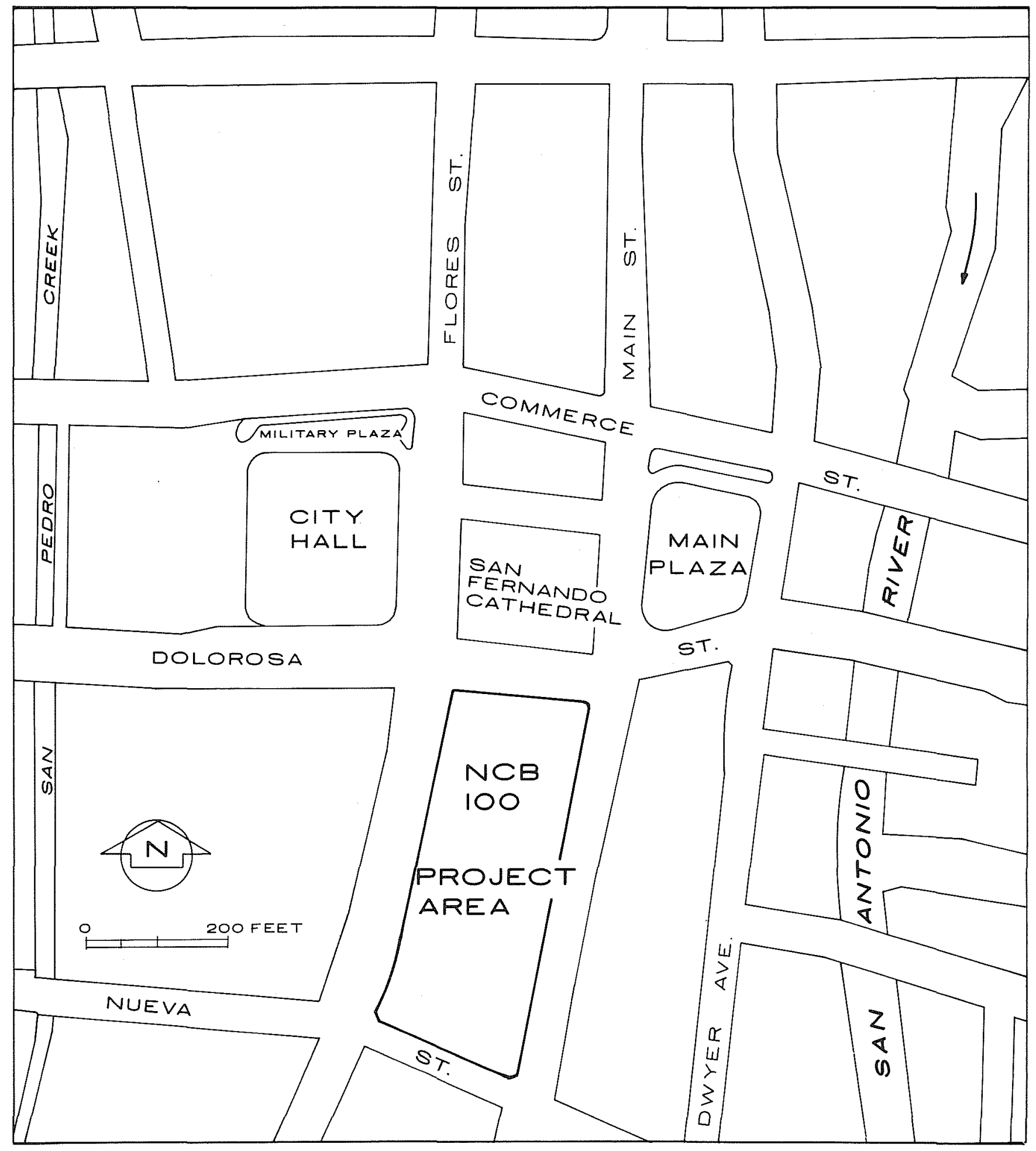

Figure 1. Project Area Location Within Downtown San Antonio. 
Plans for the new Bexar County Justice Center changed considerably over the ten-year period of our investigations. However, it was apparent from the start that a considerable portion of NCB 100 would be either completely removed for basement construction or badly disturbed by footings and foundations. The purpose of the project was to determine where undisturbed cultural deposits and features relating to the early history of San Antonio were likely to be found, and then to plan for phases of work to investigate those areas. Part of the reason for the phases of work was the necessity for the block to be used as a commercial parking lot, serving the operations at the courthouse throughout the time of the investigations. Work was planned so this function was interrupted as little as possible by working in a small section at a time, planning our trench locations carefully.

\section{PREVIOUS INVESTIGATIONS IN THE AREA}

The original 18th-century site of San Antonio consisted of Military Plaza, Main Plaza, and the areas immediately to the north and east. Results of archaeological investigations done in this area have a direct relationship to what was found on NCB 100.

The first such investigation was done by the Texas Historical Commission in 1975 before the installation of air conditioning ducts in the floor of San Fernando Cathedral (Fox, Scurlock, and Clark 1977). Excavations were also conducted in 1977 by the CAR-UTSA (Eaton n.d.) on the northwest side of the cathedral where the original sacristy was located. Information recovered during these excavations included architectural details about the original parish church which is underneath the cathedral. Cultural information was also recovered in the form of artifacts representing the earliest settlement in the area, ca. 1720 to 1738, and relating to the phases of construction and use of the church from 1738 to the present.

Another investigation in this area was done by the CAR-UTSA in 1976 next to the Spanish Governor's Palace on Military Plaza (Fox 1977). A short section of the front wall of one of the presidio buildings represented the only architectural evidence recovered. However, here again the cultural information gained through artifacts found in original context was important to interpreting the history of the first settlement.

Although not in the small, original town itself, archaeological projects at the site of Mission San Antonio de Valero (popularly called The Alamo) have also yielded important comparative artifactual information about the formative period of San Antonio. Founded at the same time as the town, the mission developed parallel to the town, so to speak, and was affected by the same historical events and subject to similar ethnic and cultural influences. Excavations at the mission by the Texas Historical Commission and the Witte Museum in 1967 (Schuetz 1966; Tunnell 1966; Greer 1967), by Schuetz in 1973 (Schuetz n.d.), and by the CAR in the northern courtyard in 1979 (Fox and Ivey n.d.), the mission plaza in 1975 (Fox, Bass, and Hester 1976), and immediately in front of the Alamo church in 1977 (Eaton 1980), have produced a body of useful information and comparative artifacts. Several CAR investigations in the La Villita section of town, especially those of 1985 (Labadie 1986) in a Mexican siege works filled with neighborhood trash, have yielded important information for dating San Antonio sites of the 1830 to 1850 period (Fox 1986:122).

\section{HISTORICAL BACKGROUND}

The study location is historically significant for several reasons. Historical and archival research has revealed that NCB 100 lies within an area known in the 18th and early 19th centuries as the Barrio del Sur, a part of the early development of the city. It was also in this general area that the Villa of San Fernando de Bexar was founded by the Canary Islanders. One early structure of particular interest has traditionally been referred to as "the Barrera house," based on the fact that the family of Agustin Barrera once lived there. Barrera served briefly as provisional governor of Texas, appointed by General Santa Anna following the Battle of the Alamo. As will be seen in the following section, the Barreras did not build the house, nor were they the first family to live there.

The main portion of the San Pedro acequia that enters the block on the northeast side and continues down its length is also of major importance to this study. The acequia, portions of which may have been constructed 
as early as 1719 , supplied water for irrigation and household purposes to the early residents of the area. Initially the acequia was simply an open, unlined ditch; then in 1852, the city contracted to have portions of the ditch lined with stone masonry laid with sand and lime mortar.

Apparently few structures were built south of the row of houses facing onto Main Plaza until after 1800, possibly as late as 1840 or 1850 . By 1873 , there was a row of small "adobe" (soft limestone block) houses facing south onto Nueva Street and another on the northeast corner of South Flores and Nueva Streets (Koch 1873). A few additional "adobe" structures clustered around the southwest corner facing onto South Flores and Nueva Streets, and others were scattered up Flores Street to Dolorosa Street. By 1885 (Fig. 2), the buildings facing onto the plazas had all become commercial operations, though many were merely remodeled residences. By the early 1900s (Fig. 3), the balance of the block was brick commercial buildings, most of which had basements. All residential use of the block had ceased by the 1950s (see Fig. 4), and larger commercial operations had taken over the entire block. The arrival and universal acceptance of the automobile dictated that a large portion of the block was given over to parking lots.

It was decided to concentrate archaeological testing on the areas known to be undisturbed by later construction, because they either had not had subsequent buildings or had minor, one-story construction that did not appear to disturb the ground beneath. By the time that archaeological research was begun, several large, late 19th-century buildings with basements on the northwest corner of the block had already been demolished, and the area was paved for parking. In addition, the entire southern third of the block had been similarly treated.

\section{LOT HISTORIES}

The histories of specific lots investigated are discussed. The amount of research time expended on the Salinas-Barrera properties reflects their relative importance in the early development of the city and also the difficulty of working with the earliest land ownership records.

\section{LOTS 1 AND 2 (Kaufman Building)}

Lots 1 and 2 passed from Francisco Flores de Abrego, an heir of the original grantee, to his son, Pedro Flores on April 1, 1852 (DR Vol. J1:179). Pedro Flores deeded the lower portion (Lots A21 and A22) to his son, another Francisco, April 14, 1860 ( $D R$ Vol. H2:433). The larger portion of the lot to the north, Pedro and his wife, Melchora, deeded to their daughters, Petra and Leonides Flores in December 1874 (DR Vol. 38:172).

In 1885 , the corner was occupied by a complex of one-story buildings housing a saloon, pawn shop, and Chinese laundry (Fig. 2). By 1888, these structures had been replaced by a two-story building (Sanborn Map and Publishing Company, Ltd. 1888). In 1895, this structure was occupied by the store of Louis Kaufman (City Directory 1895-1896). The title was contested on January 25, 1898, with the court awarding clear title of two-thirds of the property to Petra and one-third to Leonides, who in turn conveyed her portion to Petra and her husband, Patrick Crawford ( $P R$ No. 4317). The Crawfords sold the property to Kaufman in November 1905 for $\$ 26,500$ ( $D R$ Vol. 237:316). The Kaufman family continued to own the property until it was acquired by the county in preparation for construction of the new Bexar County Justice Center.

\section{LOT 3 (Luetcke-Herald Building)}

Also a portion of the Francisco Flores de Abrego grant, Lot 3 was acquired, through lines of inheritance not entirely clear, by Concepción Cervantes, wife of José Angel Navarro, and was inherited by her daughter from a previous marriage, Maria Dolores Pereida. In March 1857, she sold the property to William B. Knox for $\$ 75$ ( $D R$ Vol. O2:512). In 1862, Knox sold the lot to John Logan, George Sweet, and George Palmer who constructed a building to house their publishing establishment, the San Antonio Herald (DR Vol. O2:642, 


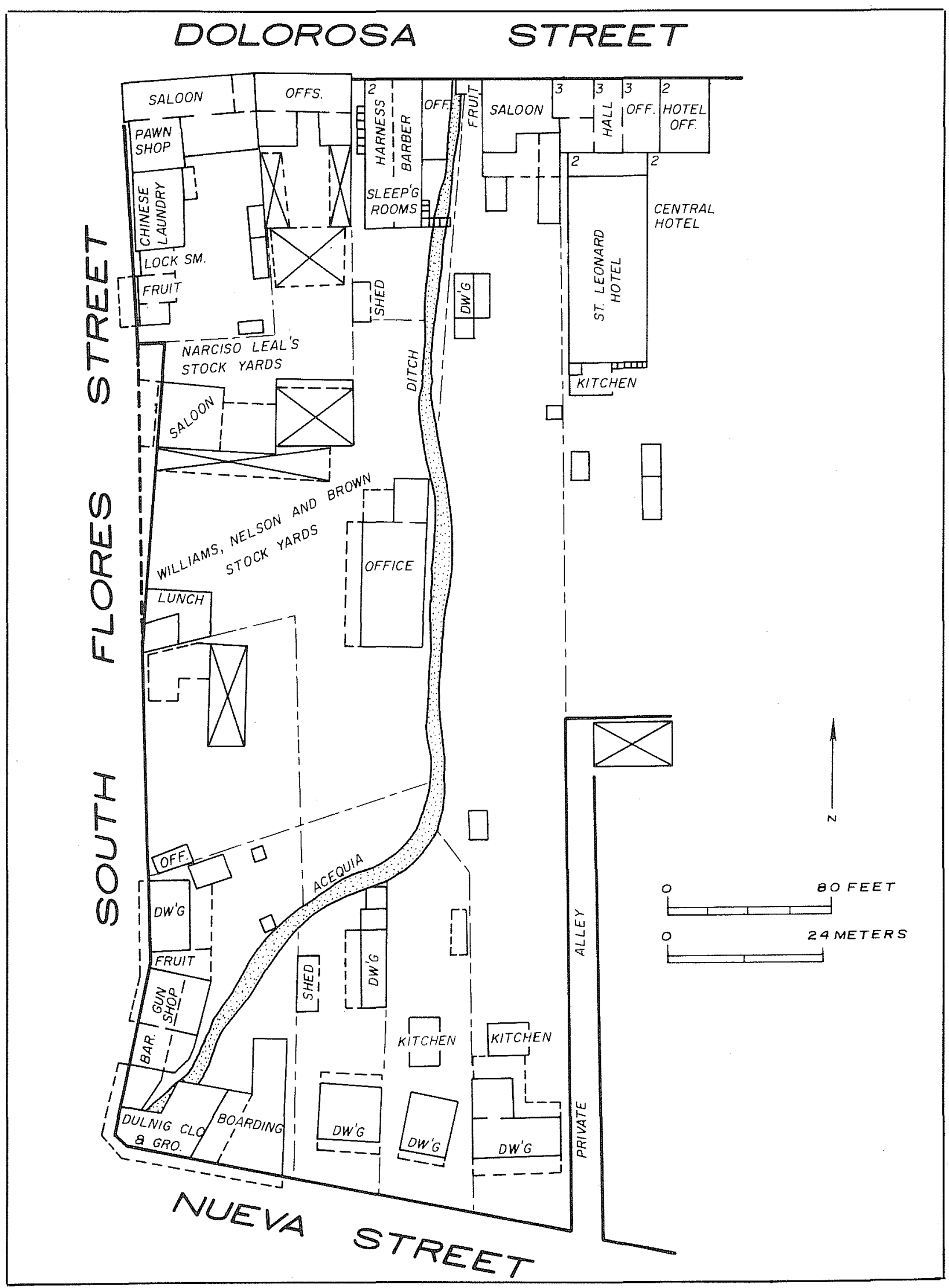

Figure 2. NCB 100 in 1885. From Sanborn Map and Publishing Company, Ltd. (1885). 


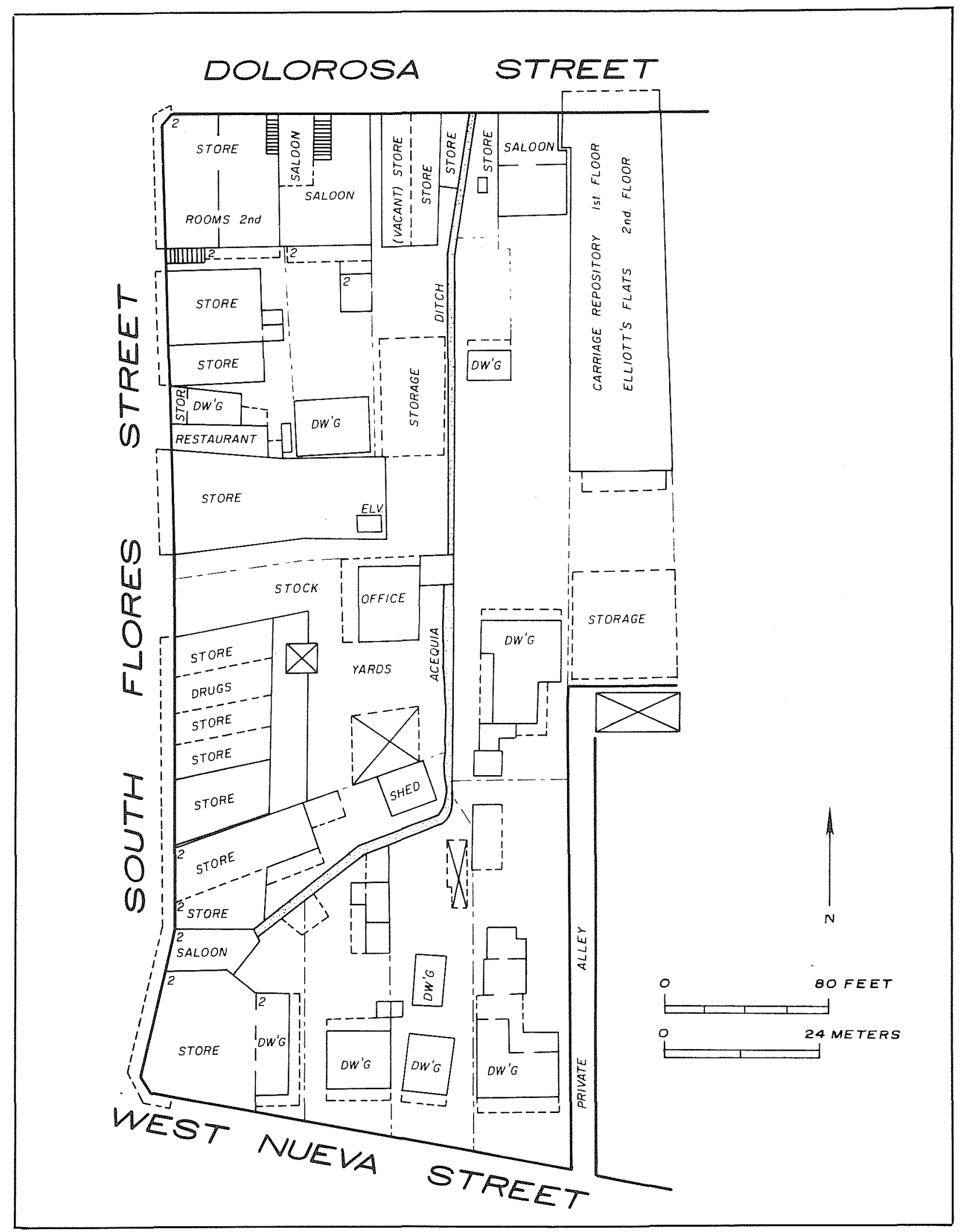

Figure 3. NCB 100 in 1904. From Sanborn Map and Publishing Company, Ltd. (1904). 


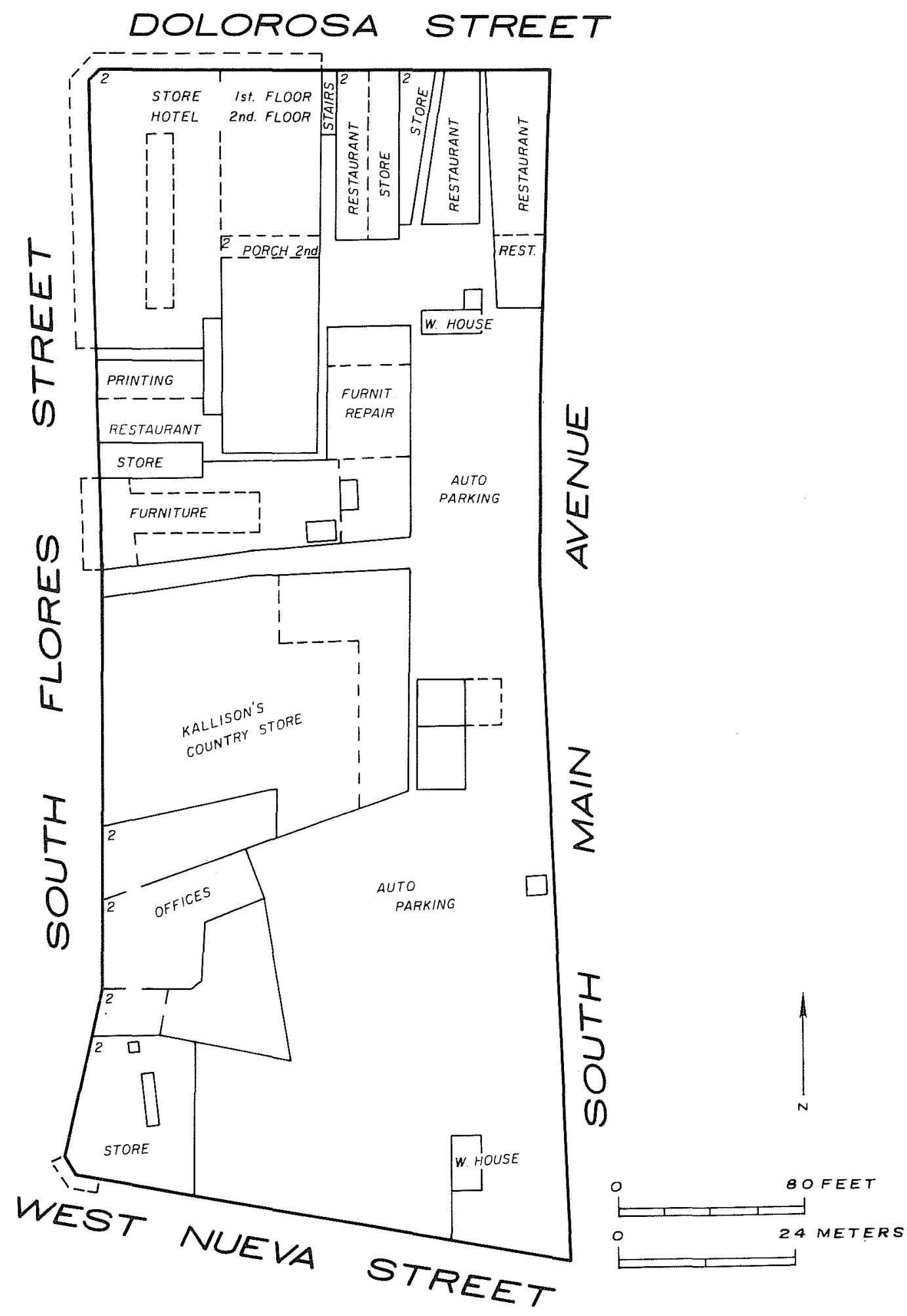

Figure 4. NCB 100 in 1952. From Sanborn Map and Publishing Company, Ltd. (1952). 
Vol. S3:369). The building was enlarged in 1866, probably with the addition of the second floor ( $D R$ Vol. T2:425). In 1874, the Herald incorporated and became the Herald Publishing Company, and then defaulted on several promissory notes and was acquired by Thomas J. Devine ( $D R$ Vol. 7:265). Upon Devine's death, March 16, 1890, his son, Albert, inherited the property. He conveyed it to Minnie Morrison and J. Lockwood in June 1900 (DR Vol. 187:335). In December 1910, Carl Luetcke purchased the property for $\$ 35,000(D R$ Vol. 351:383). He used the building as rental property, adding a red brick facade in 1926 . The property was acquired by Prudential Loan and Investment Company, and then reverted to the Grand Lodge of the Order of the Sons of Herman ( $D R$ Vol. 1263:517). It was sold by them to Morris Kallison in 1943 (DR Vol. 1947:229). Kallison sold the property to Albert A. Peña in 1946, and Peña's widow and son conveyed it to Manuel Davila in 1965 and 1967 (DR Vol. 5453:919, Vol. 5695:85).

\section{LOTS 4A, 4B, AND $\mathbf{5 B}$ (Salinas-Barrera House)}

Before discussing the history of Lots 4 and 5 on the southwest corner of Main Plaza, there are several errors in a preliminary report for this project (Ellis 1986) regarding the original ownership of the property. Ellis (1986) reported:

One early structure of particular interest ... is referred to in the Bexar County Archives as the Barrera house. The house originally belonged to Gil Ybarbo ... Ybarbo either purchased or built the house while he was in San Antonio between 1792 and 1802. The house was later occupied by Juan Barrera (son-in-law of Ybarbo) and his descendants, and subsequently became known as the Barrera house.

Additional deed research and perusal of wills and other documents now suggest that Ybarbo and Barrera did not own the property in question. As will be shown later, the earliest known owners of the property were various members of the Manuel Salinas family. One of the owners, Antonia Salinas, married Agustin Barrera, son of Juan T. Barrera (mentioned previously). This relationship, along with some nonspecific information in Chabot (1937), evidently led to the conclusion that this property originally belonged to the Barrera family, which is not the case.

\section{Early Ownership Documentation}

Chabot (1937:99) states that in 1795 Juan T. Barrera had a three-room house on the plaza in San Antonio. However, he does not indicate which plaza - Plaza de las Armas (Military Plaza) or Plaza de las Islas (Main Plaza). From other references (Spanish Archives Vol. 2:49-50, 598), it appears that this stone house was located on Plaza de las Armas. This is further supported by a report from Governor Manuel Muñoz to the Director General Silbestre Dias de la Vega (Report of Governor Manuel Muñoz 1797 microfilm roll 27, frame $565)$ in 1797 in which Barrera's house is reported to have been rented to the military as a powder house. Logically, the powder house would have been located on Military Plaza. As indicated previously, no documentation (including deeds, wills, or other documents within the Bexar County Archives) could be found that showed that Juan T. Barrera or Gil Ybarbo was ever associated with the property in question on Main Plaza.

The earliest known owner of Lots 4 and 5 is believed to be Francisco Manuel Salinas. Although deed records could not be located, other documentation strongly suggests that he owned the property in the late 1700s/early 1800s. Archival research suggests that Manuel Salinas was residing in San Antonio by 1793 (List of the Individuals of the Ayuntamienta of the Villa of San Fernando and the Residents That Voluntarily Have Contributed to the Materials for the New Cuartel, By the Order of the Commandant General of the Internal Province of New Spain 1793). Two early census tracts, 1797 and 1804, for the Villa of San Fernando list Clemente Delgado and Manuel Salinas consecutively (\#281 and \#282 [Census of Villa of San Fernando 1797] and \#134 and \#135 [List of Families in the Villa of San Fernando and the Pres(idi)o of Bexar 1804]), a strong indication that they were neighbors. It has been verified that Clemente Delgado owned the property east of the property under investigation (Rebel Properties Vol. I 1813:4; DR Vol. 2:507, Vol. H1:144; WE No. 31; also see Documents $1,2,4,6$, and 7 in this section). It is also known that by 1834 , Manuel Salinas' 
daughter, Gertrudes Salinas, owned the property in question ( $D R$ Vol. 2:507). In an 1847 deed filed by her daughter, Margarita Salinas Collantes, Erasmo Seguin testified that the property in question had originally belonged to Margarita's grandparents, Manuel Salinas and Ygnacia Flores (DR Vol. H1:182).

Maria Gertrudes Leonor Salinas was born June 30, 1793, in the Villa de San Fernando (SFBR). Her parents were Manuel Salinas and Maria Ygnacia Flores. On December 1, 1813, Gertrudes married Francisco Collantes $(S F M R)$. They had three children, Margarita, Francisco Damian, and Cosmo (SFBR, SFDR). By 1824 , Gertrudes was widowed and had given her power of attorney to Don Felipe Neri, Baron de Bastrop (DR Vol. 2:199). On January 26, 1825, Gertrudes married Manuel Flores (SFMR). By 1834, Gertrudes is mentioned in various documents as owning a house on the lot in question; however, it was never determined when or how Gertrudes initially gained ownership of the said property. As stated previously, one document mentions that her parents, Manuel Salinas and Ygnacia Flores, originally owned the property (see Document 5), and, thus, it is surmised that she obtained the property from them. The following discussion of the various documents will substantiate her ownership.

\section{Document 1}

June 5, 1834 (Spanish Archives Vol. 2:507): Manuel Flores, representing his wife, Gertrudes Salinas, filed an agreement with Francisco Rojo, a neighbor. Flores stated that Gertrudes would sell the "... house in which she lives ..." to Rojo for $\$ 400$; Gertrudes had already received $\$ 150$ towards the final payment. This document emphasizes that Rojo was not to move into this house until he fixed the roof of the house on the "... other side of the late (Clemente) Delgado ..."; this repair work would be used against the remaining $\$ 250$ owed by Rojo to Gertrudes. Once repairs were made on this house, Gertrudes would then give Rojo the deed for her current home.

Comments: This document shows that Gertrudes owned two structures, one on either side of the Delgado property (see Fig. 5,a). The first house, described as the one “... in which she lives ...." was located east of the Delgado home. This interpretation is substantiated by other documents (see Documents 2 and 4). It is likely that she inherited this house from her first husband, as an 1850 document (DR Vol. I1:40-41) refers to this house as the Francisco Collantes house. The second house, described later as a jacal (see Document 4), was located west of the Delgado home and is the one for which she contracted with Rojo to repair the roof.

\section{Document 2}

October 7, 1834 (WE No. 31): The will of Clemente Delgado and Maria Gertrudes Saucedo states that they owned a stone house on Main Plaza bounded on the east by the home of Gertrudes Salinas, on the west by the jacal of Gertrudes Salinas, and on the south by the Lower Labores.

Comments: This document supports the interpretation made for Document 1.

\section{Document 3}

July 3, $1834(S F D R)$ : On this date, Gertrudes Salinas died of a fever and was buried at Mission Espada; she left no will.

\section{Document 4}

May 1, 1847 (DR Vol. H1:144): José Maria Salinas and Antonia Salinas, brother and sister to Gertrudes, declared that their sister, Gertrudes, contracted to sell to Roxo (Rojo) her dwelling located between the properties of Clemente Delgado and Paula Seguin. The document also states that Roxo (Rojo) had died, 
Figure 5. Main Plaza in 1849 and 1868. a, W. G. M. Samuel's 1849 painting of the south side of Main Plaza; b, photograph of the south side of Main Plaza in 1868. The owners of the three houses indicated have been determined. The house (1) shown as a jacal in the 1849 painting, and later as a small masonry building in the 1868 photograph, was owned by Manuel Salinas in 1797. Later, the masonry house was owned by Gertrudes Salinas (ca. 1834-1847), José Maria Salines (1847), and Antonia Salinas (ca. 1847-1892). The two-story structure (2) in both illustrations was owned by Clemente Delgado (ca. 1813-1847), then José Antonio de la Garza (1847). The structure to the left of the two-story building (3) belonged to Gertrudes Salinas in 1834 when she sold it to Francisco Rojo. Painting and photograph are located at the Daughters of the Republic of Texas Research Library, The Alamo. 


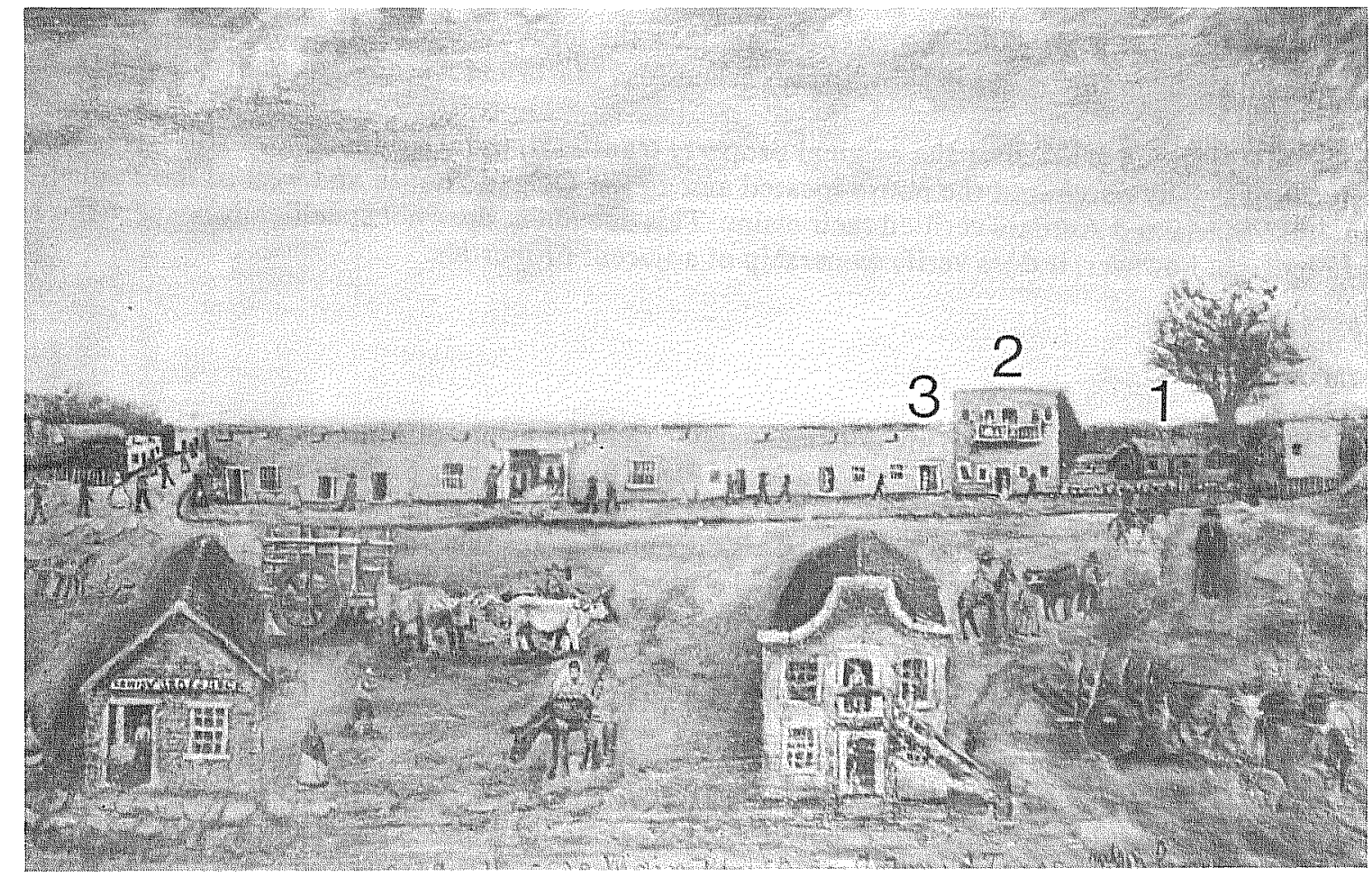

\section{a}

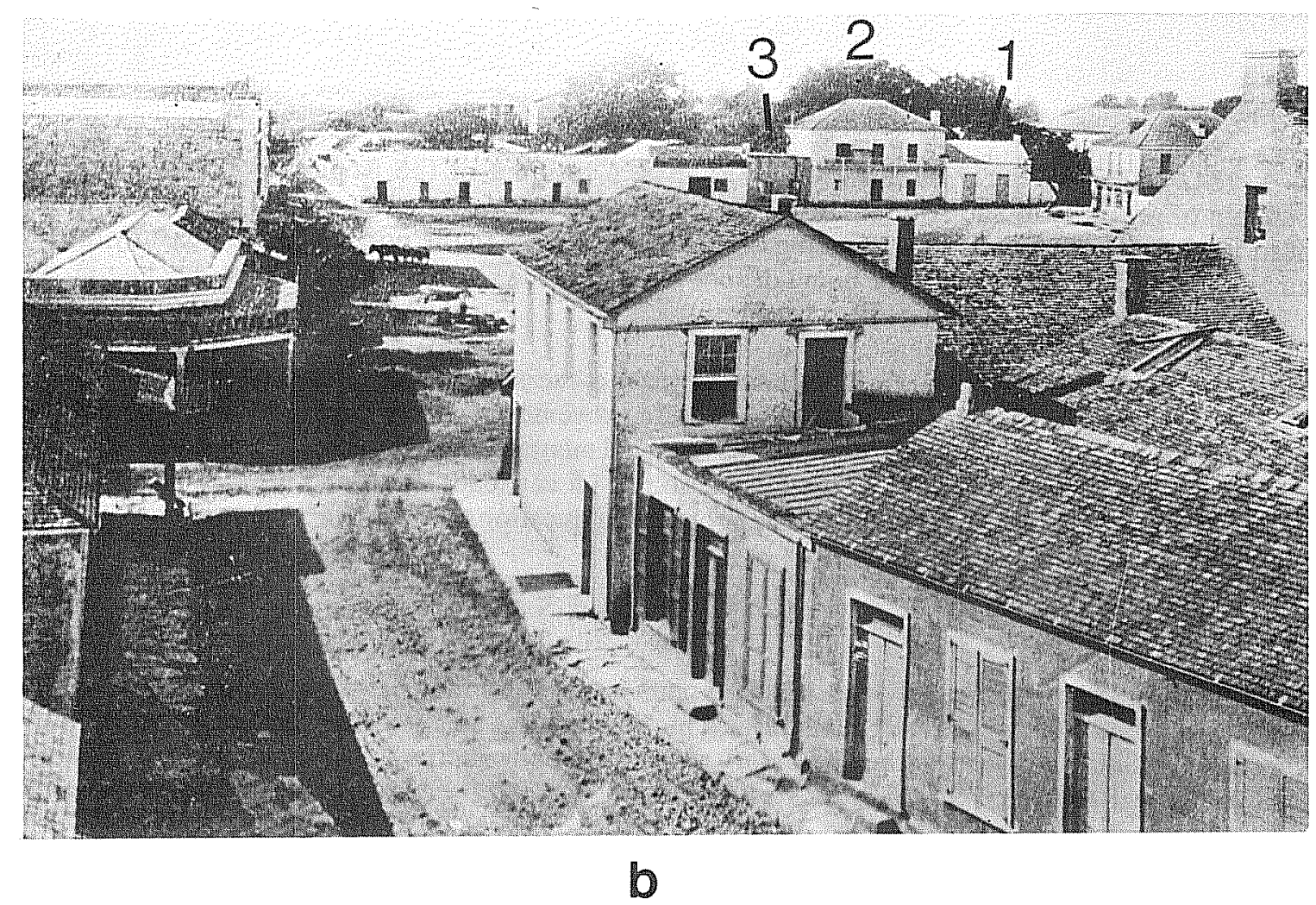


and the property was for his children. They did not have the legal document to prove that their father had bought the house from Gertrudes in 1834, so they asked José Maria and Antonia to confirm that transaction.

Comments: Thirteen years after the original property transferal, the Rojo family was still trying to prove that they had legally purchased the house located east of the Delgado house and west of the Paula Seguin house. José Maria and Antonia verified their claim. This document does not specifically concern the house under research; however, it does verify ownership of adjacent properties.

\section{Document 5}

May 1, 1847 (DR Vol. H1:182): This document states that the estate of Margarita Salinas Collantes, the daughter of Gertrudes, gave the property on Main Plaza to José Maria Salinas, her uncle. This house is described as being bounded on the north by Main Plaza, on the east by the Delgado house, on the south by the Labores, and on the west by the acequia. This document states that Margarita's mother was Gertrudes Salinas Collantes, her grandparents were Manuel Salinas and Ygnacia Flores, her uncles were Pablo and José Maria Salinas, and her aunt was Antonia Salinas. Further, Erasmo Seguin declared that he was the guardian of the interests of the late Margarita Collantes and that this particular piece of property had been property of her grandparents, Manuel Salinas and Ygnacia Flores.

Comments: This document describes the house as being located between the Delgado house (later owned by the de la Garza family; $D R$ Vol. E2:273, Vol. F2:179-180) and the acequia. It also states that the property had originally belonged to Gertrudes' parents, Manuel Salinas and Ygnacia Flores. As mentioned previously, a deed could not be located verifying their ownership or the transferal of ownership from them to Gertrudes. This document also represents one of many deed transferals within the Salinas family - the property had apparently passed from Manuel Salinas and Ygnacia Flores to Gertrudes, from Gertrudes to Margarita, from Margarita to her uncle, José Maria, and, as discussed later, he transferred the deed to his sister, Antonia Salinas, on the same day he received the property.

\section{Document 6}

May 1, 1847 ( $D R$ Vol. E2:273): José Maria Salinas, a resident of the Republic of Mexico, transferred ownership of property in San Antonio to his sister, Antonia (Maria Ana Marcelina) Salinas. The property is described as being 14 varas long, fronting on the public square to the north, bounded east by the home of Clemente Delgado and currently the home of José Antonio de la Garza, south by the street running through the Labores, and west by the main ditch (acequia).

Comments: This document verifies Antonia Salinas' ownership of the property in question. Around 1847-1849, Antonia and Agustin apparently made improvements on the property she obtained from her brother by constructing a stone house to replace the jacal mentioned previously (WE No. 31). The following document, a deed, provides proof of the acquisition of 15 cartloads of stone that may have been used to construct a more permanent structure on the property in question.

\section{Document 7}

August 5, 1847 (DR Vol. F2:179-180): This document, first shows that José Antonio de la Garza had acquired the former Clemente Delgado house. This document is an agreement between José Antonio de la Garza and Antonia Salinas to settle a boundary dispute. A patio on the south side of the de la Garza house had an adobe wall that encroached by $1 / 2$ vara (16-18 inches) onto the property of Antonia Salinas. To settle this dispute, de la Garza agreed to give Antonia 15 cartloads of rock and five pesos.

Comments: Speculation regarding the settlement of the dispute has led to some interesting conclusions. From a reference discussed previously (WE No. 31; see Document 2), we know that in 1834 the structure on this property was a jacal. A jacal is a thatch-roofed structure of poles and brush plastered with clay or adobe 
(D. Fox 1983:92; Anne A. Fox, personal communication). (For excellent photographs of a jacal, see Fehrenbach 1978:38-39 and Steinfeldt 1978:151.) In 1834, the owner, Gertrudes Salinas, made an agreement with a neighbor, Francisco Rojo, to repair the roof of the jacal. Given the fragile nature of such a structure, maintenance of this type would probably be required on a regular basis. After acquiring the property in 1847 from her brother, Antonia evidently replaced the jacal with a stone structure built with the 15 cartloads of stone obtained in the transaction with her neighbor, José Antonio de la Garza.

Interestingly, mathematical computations verify this statement. Schuetz (1968:250) reports that 100 cartloads of stone were needed to build 50 varas ( 1 vara $=33-1 / 3$ inches $)$ of wall, 2 varas high and 1 vara in thickness at Mission San Juan Capistrano. This would give us the following equation:

$$
\begin{gathered}
50 \text { varas } \times 2 \text { varas of wall } \times 1 \text { vara in thickness }=100 \text { cartloads of stone } \\
100 \text { cubic varas of wall }=100 \text { cartloads of stone } \\
1 \text { cubic vara of wall }=1 \text { cartload of stone }
\end{gathered}
$$

The average size of a small stone house for this period was approximately 3 varas long, 2 varas wide, 2 to 3 varas high, and walls for a one-story house were 3/4 vara thick (Anne Fox, personal communication). If the walls of the house were 2 varas (ca. six feet) high, the following equation can be constructed:

$$
\begin{gathered}
2 \text { (length) }+2 \text { (width) }=\text { total length of wall } \\
2(3 \text { varas })+2(2 \text { varas })=10 \text { varas in total length of wall } \\
10 \text { varas (total length) } \times 2 \text { varas (height) }=20 \text { varas } \\
20 \text { varas (total length } \times \text { height) } \times 3 / 4 \text { vara (thickness) }=15 \text { cubic varas }
\end{gathered}
$$

From the first equation we know that one cartload of stone equals one cubic vara of wall; therefore, the 15 cartloads of stone acquired in this 1847 agreement would have been enough stone to build a small house containing approximately 15 cubic varas of wall as computed.

These computations help confirm inferences made about the property in question. We know that the jacal was replaced at some point in time by a stone structure. This is verified by (1) CAR excavations which exposed portions of the foundations for a small stone house, and (2) by early (1860s-1870s) photographs of a stone house (Fig. 5,b) on the property in question. An 1849 painting by W. G. M. Samuel of the south side of Main Plaza (Fig. 5,a) depicts a jacal located west of the de la Garza house. Assuming the date on the Samuels painting is accurate, the stone house was built during or after 1849 . The stone house was situated directly adjacent to the de la Garza house (see Fig. 5,b) and apparently the same location as the jacal.

\section{Document 8}

1849 (Giraud 1849): The Giraud map is the result of a city survey made by Francis Giraud in 1849 . It shows the extent of the lot owned by Antonia Salinas and its location between the main ditch (acequia) and the property of José de la Garza, formerly the property of Clemente Delgado (Fig. 5,b).

\section{Ownership from 1880 to 1927}

By 1880, various members of the Barrera family were apparently living in Antonia Salinas' house (City Directories 1877-1878, 1879-1880). The 1877-1878 and 1879-1880 city directories list Agustin Barrera as residing at the southwest corner of Main Plaza. The latter directory also lists Sixto Barrera, grandson of Agustin Barrera and Antonia Salinas (Chabot 1937:101), as residing at the southwest corner of Main Plaza.

In 1898 and 1900, Sixto Barrera transferred the homestead to Charles Baumberger for $\$ 4500$, and in 1909 he sold the lot to A. C. Pancoast for \$14,000 (DR Vol. 172:375, Vol. 184:232, Vol. 320:259). In 1927, Main Street was extended south on the east side of the lot, and the original stone structure was replaced by a one-story brick building ( $D R$ Vol. 979:411; City Directory 1927-1928). 


\section{LOT 13}

Lot 13 is a portion of the Salinas property described with Lots $4 \mathrm{~A}, 4 \mathrm{~B}$, and $5 \mathrm{~B}$ and was granted by Agustin Barrera and his wife, Antonia Salinas, to their daughter Dolores de la Concepción Barrera in 1875 (DR Vol. 1:390). Apparently the house was already standing, since it is shown on the 1873 bird's eye view map of San Antonio (Koch 1873). Dolores married John Rosenheimer (Chabot 1937:100), an attorney and city recorder, in 1879. In 1881, they moved their residence from 218 Dolorosa Street, the Salinas homestead, to 223 Nueva Street (City Directory 1881-1882).

Their nephew, Charles A. R. Campbell, whom they were apparently rearing, also moved with them. He studied to be a druggist and was apprenticed to local druggist Adolph Dreiss until he attended Tulane, where he received a medical degree (Anonymous 1907:486). In 1886, John Rosenheimer and his wife continued living at the Nueva Street residence. In 1887, Doctor Campbell, who had married Ida Hoyer in 1885, also resided there. He inherited the property upon the death of Mrs. Rosenheimer. Dr. Campbell and his wife occupied the residence until her death in 1928, and he continued to live there until his death in 1931 (Pease n.d.). Dr. Campbell was known internationally for his numerous experiments to eradicate malaria through cultivation of colonies of bats in the San Antonio vicinity.

\section{LOT 14}

Lot 14 was conveyed in October 1855 by Thomas J. Devine to M. David and Trinidad C. Anderson for $\$ 360$ ( $D R$ Vol. N1:346). They sold the lot to Frank Egan in 1858 for $\$ 800$ ( $D R$ Vol. P2:427), suggesting that the property had probably been improved by the construction of a house. In 1871, the heirs of Egan conveyed the property to Charles Johnson for $\$ 1000$ in gold (DR Vol. W1:418). In 1910, the property was transferred by the heirs of Johnson to George $\mathbb{R}$. Stumberg for $\$ 3000$ (DR Vol. 328:219). Stumberg held considerable property on the south of Nueva Street, and he probably purchased the lot for investment property. The property appears to be residential rental until in 1914 it was occupied by A. H. Vernon as a blacksmith and horseshoeing shop (City Directories 1904-1914). Something related to this use of the lot may account for the destruction of the structures by fire before 1917 (City Directory 1917). The lot was then cleared for parking.

\section{LOT 15}

Lot 15 was subdivided by Thomas J. Devine and conveyed to Dolores Ortiz y Garcia on August 30, 1856 (DR Vol. O1:396). He had purchased it as a block containing Lots 12, 15, and 16 from Francisca de la Cruz and Miguel Chaves in February 1855 (DR Vol. M2:510). Chaves had inherited it from his mother, Maria Micaela Fragoso. Dolores Ortiz y Garcia apparently constructed her home on the lot, as she refers to it as "a homestead," and a house and outbuildings are shown on this lot on an 1873 map of San Antonio (Koch 1873). She conveyed the property to John Dullnig in February 1878 (DR Vol. 5:578). Dullnig claimed it as his residence in 1879. At the time he was a clerk in his father Jacob's store on the northeast corner of Military Plaza. In 1899, he opened his own grocery at 111 South Flores Street and moved it to 201 South Flores Street in 1902 (City Directories 1879-1902). In 1910, Dullnig moved his grocery to his residence at 227 West Nueva Street. Miss Bruhn was renting the small house at the rear of the property, where she had been since 1903 (City Directories 1903-1910). By 1917, John and Sophie Dullnig had moved to the rear structure, and the former residence was then the J. Dullnig Grocery Company (City Directory 1917). In 1944, Clara Dullnig sold the property to Nathan Kallison, and a commercial building was constructed over most of the lot. By 1950, the building had been razed for a parking lot (Fig. 4).

\section{LOTS 18, 19, AND 20}

Lots 18, 19, and 20, the original Flores de Abrago grant, were not completely documented since the area did not appear to have potential to yield significant archaeological information and was not intensively tested. In 1885, the area was occupied by the Williams, Nelson, and Brown Stockyards (Fig. 2). It remained primarily 
stockyards through 1896, and by 1904 was a complex of commercial one- and two-story buildings (Sanborn Map and Publishing Company, Ltd. 1896 to 1904). By 1952, it contained a group of two-story brick commercial buildings (Fig. 4).

\section{ARCHAEOLOGICAL INVESTIGATIONS}

\section{GEOLOGY AND SOILS}

NCB 100 is located on a low terrace between the San Antonio River and San Pedro Creek. The principal source of water for the town was an acequia or irrigation ditch that originated at the same springs that fed San Pedro Creek, and ran down this same terrace, passing through the block north to south. The block in question and the two plazas to the north are relatively level land, having an average elevation of ca. $655 \mathrm{feet}$ above mean sea level (MSL). At times of maximum rainfall, such as during a major storm or a hurricane, the waters of the San Antonio River and San Pedro Creek have been known to merge and completely cover the townsite (Hatcher 1935:331; James 1938:45).

Soils in this general area consist of Lewisville-Houston Black, terrace association soils. On NCB 100, the soil was observed to best fit the description of Lewisville Silty Clay (Taylor, Hailey, and Richmond 1966:5), being a deep, dark grayish brown to brown clay loam of crumbly consistency. Deeper soil at the subsurface ranges from dark brown to reddish brown clay loam.

\section{METHODOLOGY}

During the research and planning stage of this project, all available historic maps of the city were collected and studied for clues about the development of NCB 100. Copies of Sanborn insurance maps of the area were reduced to the same scale and overlaid to give a picture of the foundations likely to be encountered beneath the surface, and a search was made of available information on areas that might be still undisturbed. Using this information, test trenches were laid out on the composite map across structures to be examined in such a way as to reveal the exact location, types of construction, etc., as well as to yield a related artifact sample to confirm dates of construction and occupation.

In the field, the trenches were excavated in the following manner. The area to be investigated was barricaded off from the rest of the parking lot. An outline of each trench was carefully measured from the curb lines and marked on the asphalt surface with spray enamel. The edges of the trench were then cut through the asphalt by machine, assuring minimum damage to the surface of the lot. This was necessary in order that the trenches could be quickly repaved and the area immediately put back into service in order to cause as little disruption as possible in the use of the lot.

A backhoe with a two-foot-wide bucket was then moved into place, and excavation of the trench was begun. Individual phases required different methods of excavation, recording, and artifact recovery which will be discussed in the following sections. Overall, however, the policy followed was to use the backhoe to remove the asphalt surface and the gravel base below, then to carefully lift off successive layers of building demolition rubble and debris until the tops of foundations were encountered. One or more archaeologists were present and actively supervising all backhoe excavations, ready to stop the machine and change to hand excavation at the first sign of in situ deposits or architectural features. How deep to carry the backhoe excavation was in each case an individual decision, based on observations of soil color and texture and artifact content.

When excavations reached sterile soil, the walls and floors of trenches were troweled, and architectural features were cleaned with trowel and brush. Selected profiles were then drawn and photographed. All artifacts noted during backhoe excavation were collected in specially marked bags, noting exact provenience wherever possible. Controlled excavations and screening of the soil were done selectively, and will be described in individual phase descriptions. Specific artifact collections were made from the vicinity of 
architectural features while hand cleaning. Soil samples were taken from observable strata in trench walls for later comparison and analysis in the laboratory. Vertical control was generally maintained by observing natural or man-made stratification; however, in Phase IV one block was excavated in 10-cm levels in order to obtain tighter control over a stratum that appeared to be undisturbed.

Daily journals were kept by the supervisor and field director and by individuals excavating specific features. Level reports were used where pertinent, and trenches and features were drawn to scale on blueline maps of the block provided by the county. Elevations within the trenches were measured from the surface of the asphalt, considering this level as a datum plane over the entire site.

All field notes, journals, drawings, maps, photographs, and research materials are on file at the CAR-UTSA, along with the artifacts and soil samples recovered. Each individual structure investigated has been assigned a standard trinomial site number by the Texas Archeological Research Laboratory in Austin.

\section{PHASE I}

In July 1978, a CAR archaeological crew consisting of two graduate students and a number of student volunteers under the direction of the senior author conducted test trenching at the south end of NCB 100 (Figs. 6, 7). The purpose of the testing was to determine what cultural remains were still present beneath the parking lot pavement. At that time, the county was planning to build an annex to the courthouse on the property. Preliminary research had indicated that in 1873 there had been a group of small "adobe" (actually soft limestone) houses on the southeast corner of the block, and a row of smaller houses along the west edge of the block at the southwest corner. The houses on the southwest corner had commercial buildings constructed over them by 1920 , but the houses on the southeast corner had survived until the 1950s when they were razed, and the area was immediately made into a parking lot. It was hoped that testing in this portion of the block would yield information on the comparative condition of the historical remains that had been covered with more recent buildings versus those that had been covered with asphalt paving. Such information would be useful in determining what additional areas of the block should be excavated before the new courthouse annex was built.

\section{WEST NUEVA STREET (41 BX 334)}

\section{Structural History}

The "adobe" house and its related kitchen, located at 223 West Nueva Street, were apparently built before 1873. In 1873, the kitchen was a separate building. By 1885 , the two structures had been joined by building a porch between them. In 1904 (Fig. 3), there was a frame addition on the north end of the kitchen. The entire structure was razed by 1950 .

\section{Archaeological Testing}

Trench 1 was laid out north-south across the locations of the Campbell kitchen and house. Starting at the north end of the trench, the following features were exposed and recorded. Munsell color codes were not recorded during this part of the project.

Outside of the north kitchen wall (Fig. 8,a) a dark brown layer of soil found below the gravel base for the asphalt parking surface, contained numerous small artifacts (Table 2,d). A builder's trench, $10 \mathrm{~cm}$ (four inches) wide, was found on either side of the limestone foundation for the kitchen wall. Fragments of brick were found in the top of the trench on the outside of the wall. 


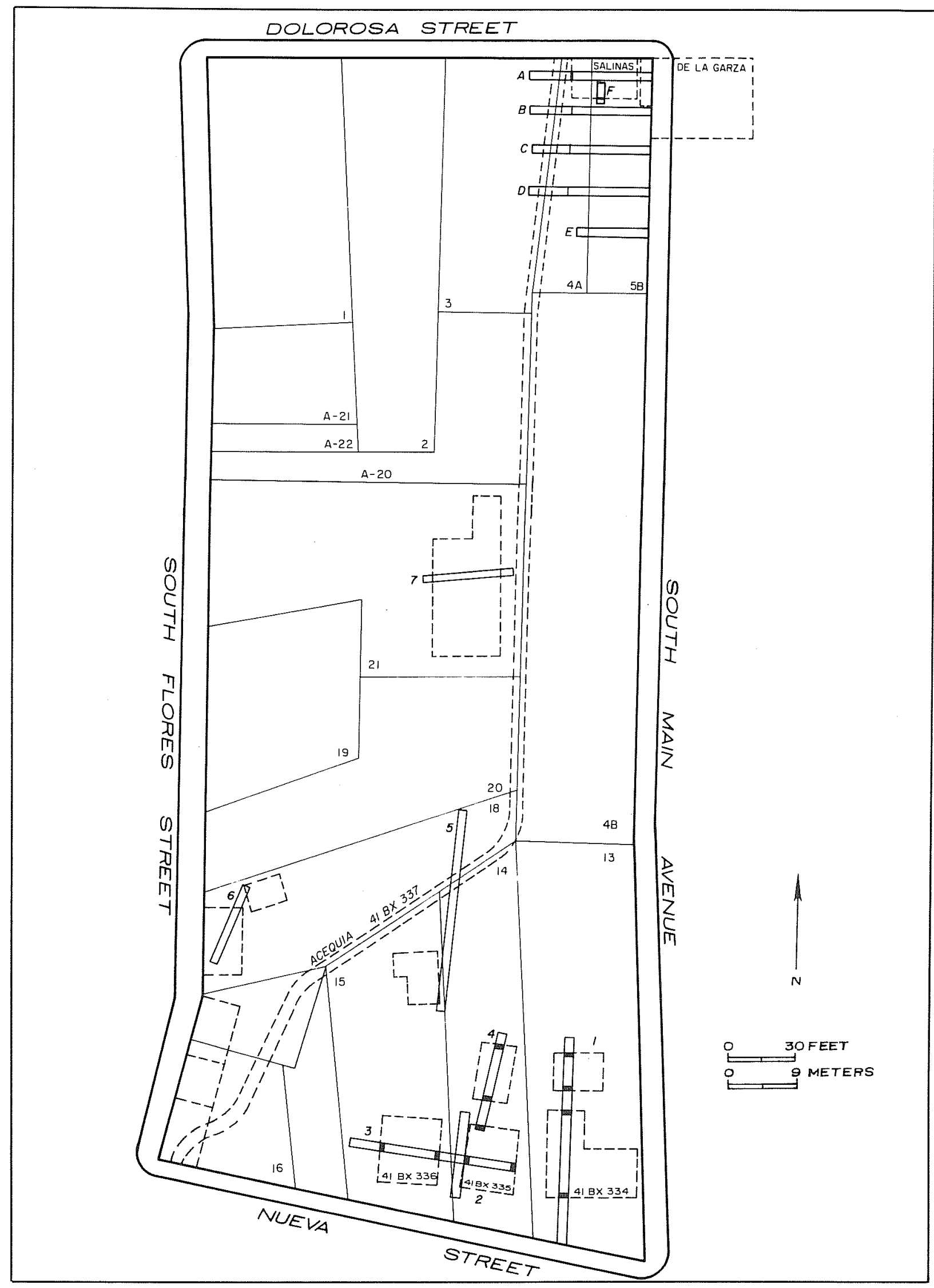

Figure 6. NCB 100, Showing Areas of Investigation. Trenches 1 to 7 are Phase I excavations; Trenches $\mathrm{A}$ to $\mathrm{F}$ are Phase III and Phase IV. 


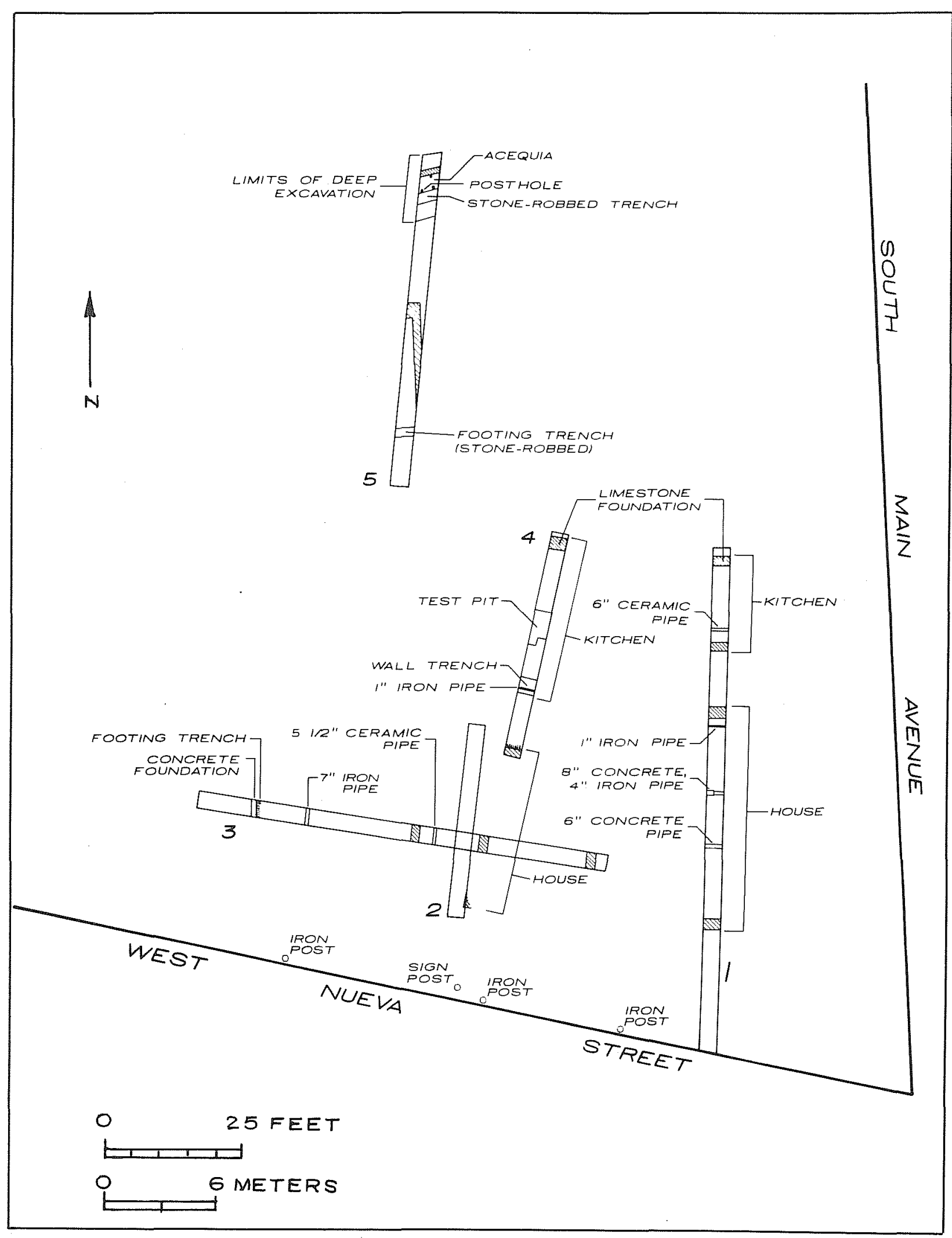

Figure 7. Phase I Excavations. Locations for house walls are shown in the backhoe trenches. 

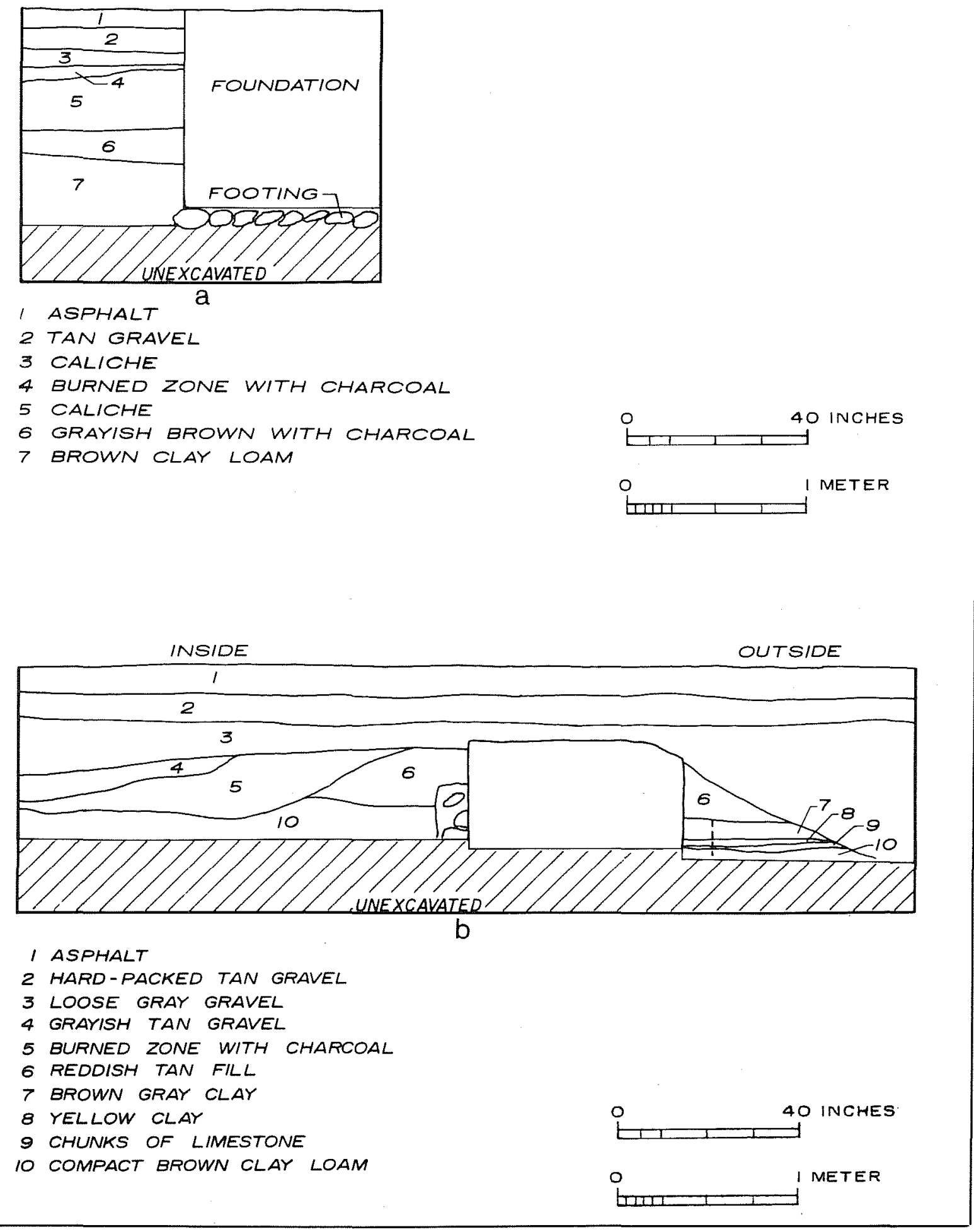

Figure 8. Phase I Profiles for 41 BX 334. a, north wall of kitchen, west profile of Trench 1; $b$, north wall of house, east profile of Trench 1. 
TABLE 2. ARTIFACTS FROM 223 WEST NUEVA STREET (41 BX 334)

\begin{tabular}{|c|c|c|c|}
\hline ARTIFACT TYPE & $\begin{array}{l}\text { NUMBER OF } \\
\text { SPECIMENS }\end{array}$ & ARTIFACT TYPE & $\begin{array}{l}\text { NUMBER OF } \\
\text { SPECIMENS }\end{array}$ \\
\hline $\begin{array}{l}\text { a, beneath kitchen } \\
\text { Activity Items } \\
\text { Porcelain doll } \\
\text { Clothing } \\
\text { Buckle } \\
\text { Construction Items } \\
\text { Brick, red } \\
\text { Ceramic sewer pipe } \\
\text { Nails } \\
\text { Plaster } \\
\text { b, between kitchen and house } \\
\text { Construction Items } \\
\text { Brick } \\
\text { Ceramic tile, grooved } \\
\text { Metal, cuprous } \\
\text { Nails } \\
\text { Window glass } \\
\text { Household Items } \\
\text { Flower pot, unglazed } \\
\text { Kitchen/Dining Items } \\
\text { Glass container } \\
\text { Tin can scrap } \\
\\
\text { c, house area } \\
\text { Activity Items } \\
\text { Copper printing plates } \\
\text { Construction Items } \\
\text { Brick } \\
\text { Ceramic tile } \\
\text { Metal, miscellaneous } \\
\text { Nails } \\
\text { Plaster } \\
\text { Wire }\end{array}$ & $\begin{array}{r}14 \\
1 \\
1 \\
7 \\
3 \\
2 \\
1 \\
14\end{array}$ & $\begin{array}{l}\text { Household Item } \\
\text { Flower pot, stoneware } \\
\text { Kitchen/Dining Items } \\
\text { Bone } \\
\text { Bottle caps } \\
\text { Ceramics } \\
\text { Porcelain (French mark) } \\
\text { Glass container fragments } \\
\text { Tin can bottom } \\
\text { d, north of kitchen } \\
\text { Clothing } \\
\text { Buttons } \\
\text { Construction Items } \\
\text { Iron bolt } \\
\text { Insulated wire } \\
\text { Nails } \\
\text { Plaster } \\
\text { Window glass } \\
\text { Kitchen/Dining Items } \\
\text { Beer mug } \\
\text { Bone } \\
\text { Bottle cap } \\
\text { Ceramics } \\
\text { Burnished earthenware } \\
\text { Porcelain } \\
\text { Egg shells } \\
\text { Glass container fragments } \\
\text { Glass stopper } \\
\text { Iron scrap }\end{array}$ & $\begin{array}{r}3 \\
1 \\
17 \\
4 \\
8 \\
3 \\
50 \\
1 \\
1 \\
1 \\
2 \\
21 \\
1 \\
10\end{array}$ \\
\hline
\end{tabular}

The kitchen wall foundation had been dug into sterile dark brown clay loam typical of that found beneath most of the city. The remaining foundation consisted of two layers of cut limestone blocks, each block measuring approximately $30 \times 45 \times 20 \mathrm{~cm}(12 \times 18 \times 8$ inches $)$, laid in sandy lime mortar.

Beneath the kitchen floor, the soil consisted of a layer of gray tan loam containing limestone chips and chunks and plaster (Table 2,a). A thin lens of brown friable soil covered the top of the builder's trench, and below this was a layer of tan, sandy clay loam that contained lenses of caliche. Near the bottom of the foundation, this layer was underlain by the sterile dark brown clay loam.

The south wall foundation of the kitchen was found to be constructed in the same manner as that of the north. North of the south wall of the kitchen ( $60 \mathrm{~cm}$ [24 inches]), a 15-cm (six-inch) ceramic sewer pipe ran across the trench, parallel to the wall. A notch $(5 \times 5 \times 15 \mathrm{~cm}[2 \times 2 \times 6$ inches] deep) cut into the top of the southern half of the wall foundation would appear to have been made to receive supports for flooring in the porch area between the kitchen and the main house, constructed between 1873 and 1885 .

The soil in the area between the kitchen and the house, below the parking lot fill, was a heavy variegated dark brown clay, very dense and impossible to trowel. Artifacts found there (Table 2,b) were not particularly diagnostic, but appear to be mostly from the time of demolition of the buildings.

The foundation of the house also of cut limestone, set in sand and lime mortar, was $60 \mathrm{~cm}$ (24 inches) wide (Fig. 8,b). The soil beneath the house was identical to that between the house and the kitchen. Artifacts found in that area (Table 2,c) were not remarkable, with the exception of a cache of 11 copper printing plates found beneath the front porch that bore the imprints of illustrations from Dr. Campbell's (1925) book, Bats, Mosquitoes and Dollars. One interesting thing about these plates is the fact that several of the illustrations did not appear in the book, perhaps victims of a zealous editor during the last stages of production of the 
book. Two concrete-covered iron pipes and a one-inch iron pipe (Fig. 7) were found to cross the test trench beneath the house.

Summary

Trench 1 uncovered the walls of the Campbell house and its detached kitchen. The original ground surface appeared to be virtually undisturbed by the demolition of the house and subsequent construction of the parking lot over the foundations.

225 WEST NUEVA STREET (41 BX 335)

\section{Structural History}

A small "adobe" house and detached frame and stone kitchen were built before the Civil War at 225 West Nueva Street. By 1888, a shed had been built on the east lot line, behind the kitchen (Sanborn Map and Publishing Company, Ltd. 1888). By 1904, apparently the kitchen had been converted into a dwelling (Fig. 3). Sometime between 1904 and 1923, the house and kitchen burned, and the whole lot was cleared of structures (Sanborn Map and Publishing Company, Ltd. 1923).

\section{Archaeological Testing}

Three test trenches crossed this site. Trench 2 just caught the outside of the southwest corner of the house (Figs. 7, 9,a). Trench 3 revealed the east and west walls and the ground beneath the house. Trench 4 revealed the north and south walls of the kitchen and the north wall of the house.

Evidence of the deposits outside the west wall of the house was found in Trenches 2 and 3 (Table 3,a). As might be expected, the artifacts represented the entire time period of the life of the house.

In the section of Trench 3 beneath the house (Table 3,b), the artifacts were primarily representative of the pre-Civil War period, with the addition of demolition debris from the razing of the structure. The house foundation, as revealed in Trenches 2,3 , and 4, consisted of cut limestone blocks with sandy lime mortar set in a narrow footing trench slightly wider than the wall. The foundations were $45 \mathrm{~cm}$ (18 inches) wide. From the amount of plaster present in the demolition fill, it was apparent that the house had been plastered both inside and outside.

As revealed in Trench 4, the north kitchen wall foundation was of cut limestone, $60 \mathrm{~cm}$ (24 inches) wide, mortared with mud. The foundation stones were set into a trench the exact width of the intended wall in typical Spanish fashion. Artifacts from an excavation north of the kitchen wall (Table 3,c) represent the entire time range of the occupation of the house. The south wall of the kitchen had been removed, and the wall trench had become a pipe trench into which a one-inch metal pipe had been laid.

The ceiling beams of the kitchen had apparently collapsed during or after the fire, as large sections of blue-painted wood overlay the burned layer beneath the kitchen. Several coats of the same blue paint had been applied to fragments of wall plaster found in the same deposit. A 1.8-m (6-foot) section of the burned layer inside the kitchen was troweled to a depth of $50 \mathrm{~cm}$ (20 inches) below the asphalt surface. The artifacts recovered (Table 3,d) date to the last quarter of the 19th century and may represent objects in use and present within the structure when it burned.

The original ground level between the house and kitchen was found to be $40 \mathrm{~cm}$ (16 inches) below the top of the asphalt, and the foundation trenches were dug from that level. Above this level was a layer of burned material that extended both inside and outside the house. Artifacts removed from this area (Table 3,e) were 

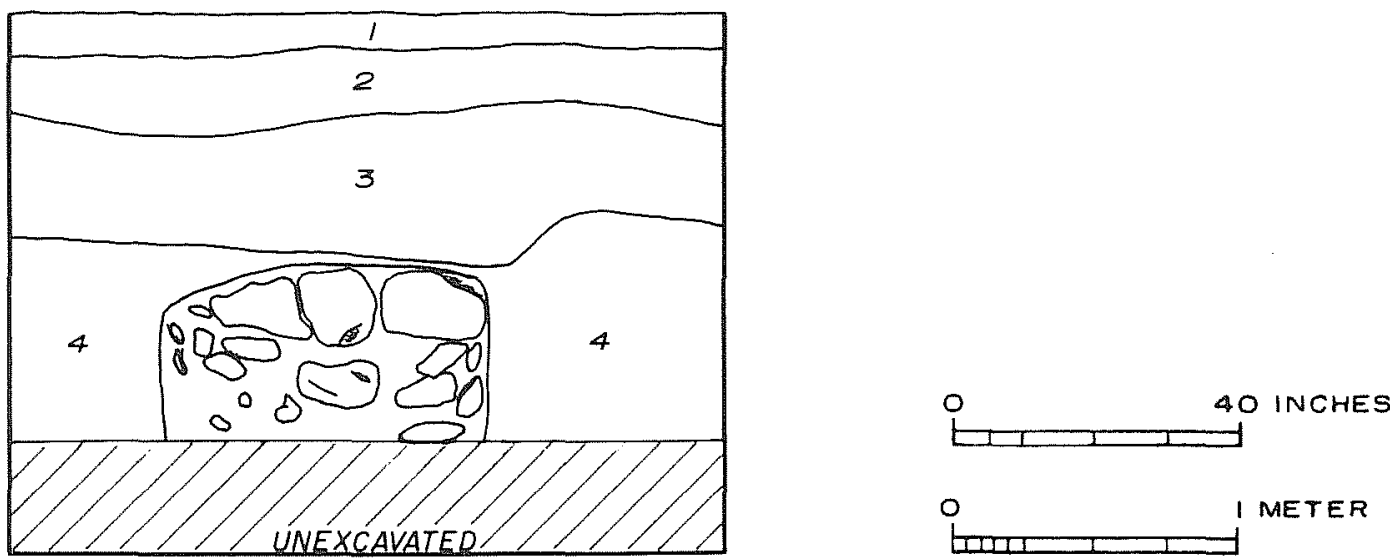

I ASPHALT

a

2 HARD-PACKED TAN GRAVEL

3 LOOSE GRAYISH TAN GRAVEL

4 COMPACT BROWN CLAY LOAM
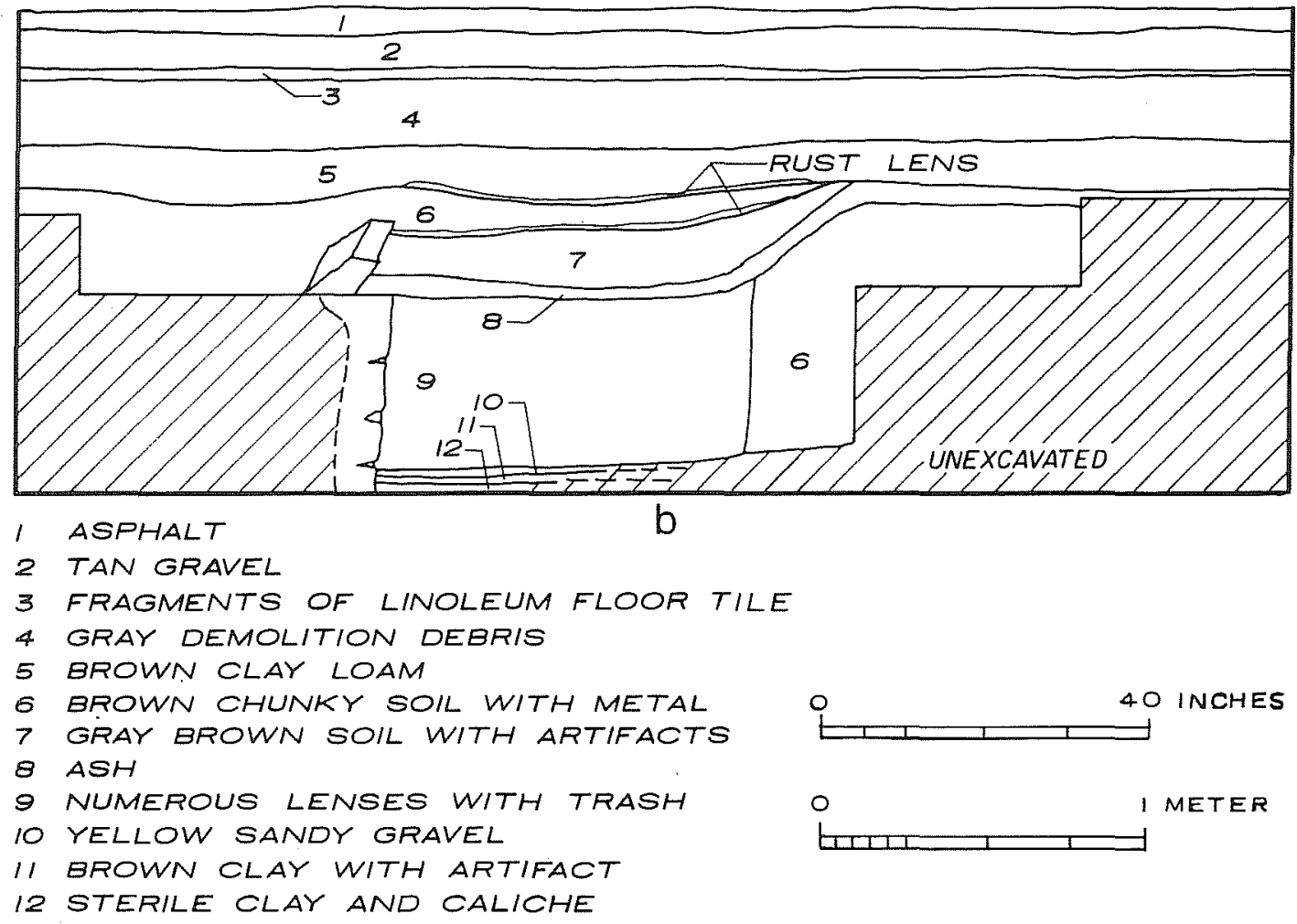

Figure 9. Phase I Profiles for $41 B X 335$ and $41 B X 337$. a, southwest corner of house at $41 \mathrm{BX} 335$, east profile of Trench 2; b, east profile of Trench 5 at acequia, $41 \mathrm{BX} 337$. 
TABLE 3. ARTIFACTS FROM 225 WEST NUEVA STREET (41 BX 335)

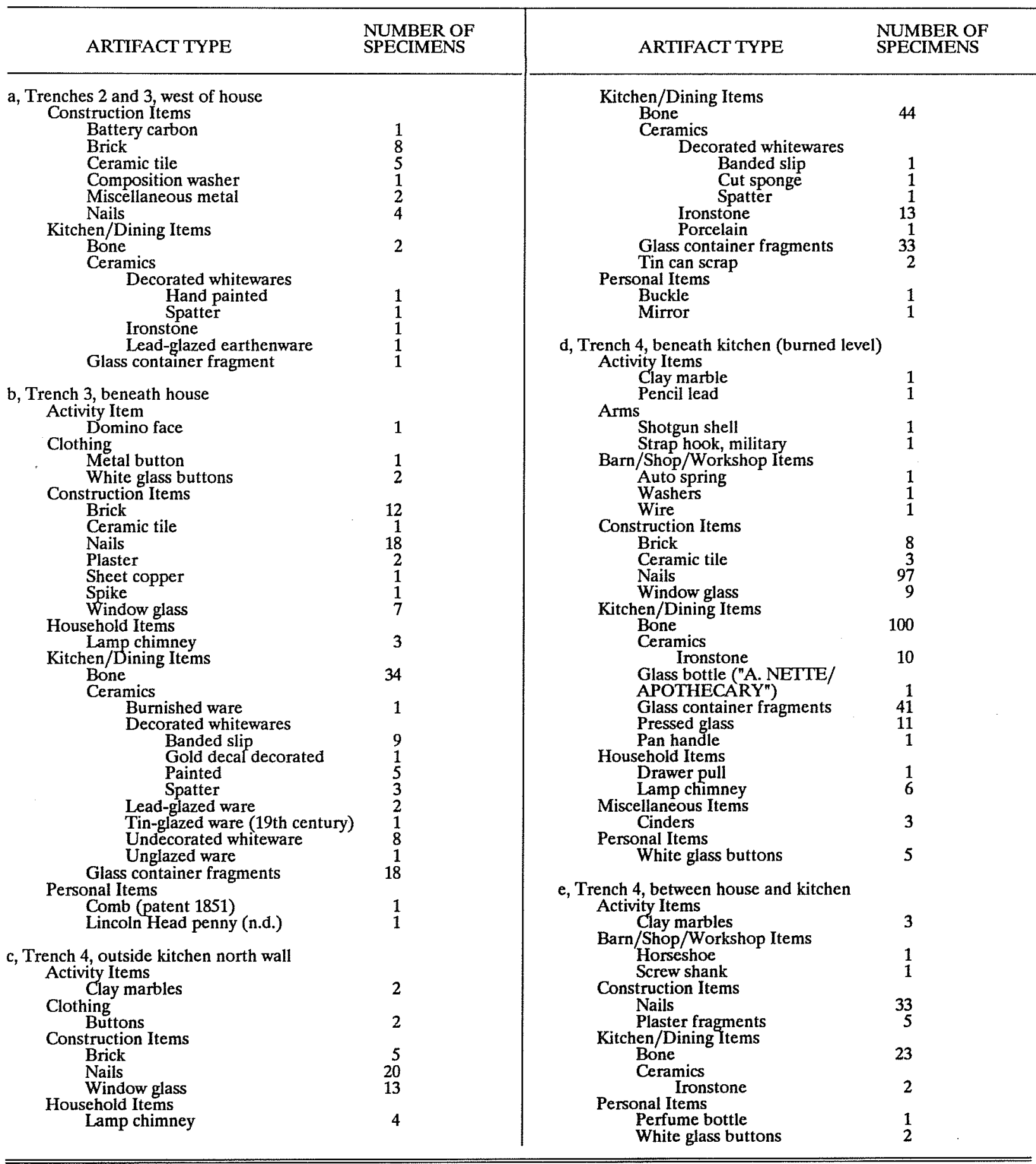


mostly the sort of small objects that might have been lost or discarded and not noticed by the residents of the house.

\section{Summary}

Here again, the preservation of original ground surfaces appeared to be good, including a layer of charcoal that probably indicated the destruction of the buildings by fire sometime early in the 20th century. The artifactual and archival information suggests that the building at the rear had varied uses throughout the life of the structure.

\section{WEST NUEVA STREET (41 BX 336)}

\section{Structural History}

The small "adobe" house at the front of the lot located at 227 West Nueva Street was probably built in 1856. Sometime before 1873 (Koch 1873), another "adobe" structure had been built on the east lot line some distance to the rear. By 1885 , several small rooms had been added to the rear "adobe" building. The structure may have first been intended as a shed or storage building, but by 1885 (Fig. 2), it was being used as a dwelling and had been assigned a separate house number (227-1/2). By 1917, the house in the front of the lot had become a grocery store, the proprietor then living in the house at the rear.

The buildings were razed in 1944 in preparation for construction of a commercial building facing onto South Flores Street. At this time, there was a well in the yard between the front and rear structures (James Kallison, personal communication). The wall was not found during Phase I work.

\section{Archaeological Testing}

Two test trenches exposed information about $41 \mathrm{BX} 336$. Trench 3, extending from the house at 225 West Nueva Street, crossed the house at the front of this lot as well. Trench 5 crossed the small dwelling on the back of the lot.

Trench 3 revealed a 5-1/2-inch ceramic pipeline running north-south between the houses, then a $45-\mathrm{cm}$ (18-inch)-wide cut limestone foundation for the house/store building. Artifacts found in cleaning this wall and area immediately around it (Table 4,a,b) were few, and none were particularly diagnostic.

Next encountered within the house foundation was an iron pipe, followed by an area of obvious disturbance containing red clay and gravel within which was found a concrete footing. Apparently this had replaced the west foundation wall of the house, perhaps as part of the new building constructed in the 1940s. Artifacts found in the general vicinity of this feature (Table 4,c) included 80 wire nails, which probably also reflected the new construction.

The east wall of the small structure at the back of the lot was found to cross Trench 5 at a slight angle, about $45 \mathrm{~cm}$ (18 inches) below the surface. This foundation was $41 \mathrm{~cm}$ (16 inches) wide and made of carelessly laid, unshaped limestone. A stone-robbed trench was the only indication found of the south wall of what was probably the original "adobe" section of the building.

Artifacts found beneath this structure (Table 4,d), primarily in the construction trench of the east wall, included painted plaster, animal bones, a painted clay marble, glass fragments, sherds of hand-painted ware and spatterware, and part of a stoneware crock. The presence of English sherds on this site reflects its first occupation in the $1850 \mathrm{~s}$, and suggests that the small house at the rear may have predated the house at the front of the lot, serving as a dwelling for some time before the latter was constructed. 
TABLE 4. ARTIFACTS FROM 227 WEST NUEVA STREET (41 BX 336)

\begin{tabular}{|c|c|c|c|}
\hline ARTIFACT TYPE & $\begin{array}{l}\text { NUMBER OF } \\
\text { SPECIMENS }\end{array}$ & ARTIFACT TYPE & $\begin{array}{l}\text { NUMBER OF } \\
\text { SPECIMENS }\end{array}$ \\
\hline $\begin{array}{l}\text { a, outside east wall } \\
\text { Construction Items } \\
\text { Brick and tile } \\
\text { Ceramic sewer pipe } \\
\text { Nails } \\
\text { Kitchen/Dining Items } \\
\text { Glass container fragments } \\
\text { b, cast wall } \\
\text { Activity Item } \\
\text { Slate fragment } \\
\text { Construction Items } \\
\text { Ceramic tile } \\
\text { Nails } \\
\text { Plaster } \\
\text { Kitchen/Dining Items } \\
\text { Glass container fragments } \\
\\
\text { c, beneath house } \\
\text { Construction Items } \\
\text { Metal rods } \\
\text { Nails } \\
\text { Plaster } \\
\text { Screw } \\
\text { Wire }\end{array}$ & $\begin{array}{l}1 \\
5 \\
3 \\
1 \\
4\end{array}$ & $\begin{array}{c}\text { Kitchen/Dining Items } \\
\text { Ceramic } \\
\text { Hand-painted whiteware } \\
\text { Glass container fragments } \\
\text { Personal Item } \\
\text { Leather shoe sole } \\
\text { d, inside second dwelling } \\
\text { Activity Item } \\
\text { Marble } \\
\text { Construction Items } \\
\text { Ceramic tile } \\
\text { Plaster } \\
\text { Tack } \\
\text { Household Item } \\
\text { Flower pot } \\
\text { Kitchen/Dining Items } \\
\text { Bone } \\
\text { Ceramics } \\
\text { Decorated whitewares } \\
\text { Hand painted } \\
\text { Spatter } \\
\text { Stoneware } \\
\text { Glass container fragments }\end{array}$ & $\begin{array}{l}1 \\
1 \\
3 \\
1 \\
1 \\
9\end{array}$ \\
\hline
\end{tabular}

\section{Summary}

The west wall of the structure at the front of the lot had later been replaced by a concrete foundation, and the entire area of the house was disturbed during this operation and the subsequent demolition of the later building. However, a small outbuilding at the back of the lot near the acequia, investigated by Trench 5 , appeared to be in better condition. The foundation of this shedlike building is made of unshaped stone, some of which has been removed, leaving only the original footing trenches. Use of this structure, judging from the artifacts, was from the mid 1800s to the early 1900 s. It apparently was the home of the Dullnig family when they converted their residence at the front of the lot into a store around 1900.

SAN PEDRO ACEQUIA (41 BX 337)

\section{$\underline{\text { Structural History }}$}

The acequia, or irrigation ditch, was built in the early 18th century (Fox 1978b:7). The section through the center of town was lined with cut stone in the mid-19th century. However, from the Sanborn insurance maps, it appears that the section of the acequia through NCB 100 was not lined until sometime between 1888 and 1892. The ditch provided water for the use of households located along its banks until the late 19th century. When the citizens became convinced that the open ditch was a health hazard, it was closed ca. 1906, rapidly filled with trash, and covered with earth. Although the ditch was no longer in use, or even visible in most areas, its location has continued as a property boundary from that time forward. 


\section{Archaeological Testing}

Trench 5 crossed the acequia behind 41 BX 336. It was first noted as a large area of late 19th-century and early 20th-century trash in the bottom of the trench. The trench was cleaned off to $60 \mathrm{~cm}$ ( 24 inches) at that point, and excavation of this area was begun with the expectation of finding the acequia. This was based on the fact that the artifacts represented the time when it was going out of use and was probably being used as a trash dump, as in other parts of San Antonio (see Schuetz 1970).

All material removed from the unit was screened. A layer of gray clay containing charcoal, rusted metal, and artifacts was found to cap the deposits. Below this, the fill was loose and contained more artifacts (Fig. 9,b). At $86 \mathrm{~cm}$ (36 inches), the top of the north wall of the acequia lining was encountered, but there was still no sign of the south wall. The contents were then excavated in several discrete levels for the sake of control (Table 5). A cedar post was found inside the north wall of the acequia, and another outside what was later found to be the line of the south wall. These may have been lot boundary fences installed after the filling in of the acequia, since the bottom of the northern post was found to be slightly above the level of the bottom of the acequia. At $113 \mathrm{~cm}$ (44 inches), the fill became more compact, but the same types of artifacts appeared to continue. The bottom of the ditch was found to be $154 \mathrm{~cm}$ ( 60 inches) below the surface. There was a layer of cobbles and limestone chunks on the bottom, perhaps the result of shaping stones for the lining. The south wall of the acequia had been robbed of its stone, but the wall trench was still visible in the profile of the trench. A dark gray clay south of the wall trench was filled with charcoal, bricks, and a few artifacts of the same time period as those within the ditch. Analysis and cross-mending of artifacts from the acequia fill $($ Table 6,a,b) indicate that the fill was probably put into the ditch in one episode after the turn of the century, possibly from trash deposits from the backs of surrounding lots in the area.

TABLE 5. ARTIFACTS FROM THE SAN PEDRO ACEQUIA (41 BX 337)

\begin{tabular}{|c|c|c|c|}
\hline ARTIFACT TYPE & $\begin{array}{l}\text { NUMBER OF } \\
\text { SPECIMENS }\end{array}$ & ARTIFACT TYPE & $\begin{array}{l}\text { NUMBER OF } \\
\text { SPECIMENS }\end{array}$ \\
\hline $\begin{array}{l}\text { 0-24 inches } \\
\text { Activity Items } \\
\text { Doll parts } \\
\text { Slate fragments } \\
\text { Barn/Shop/Workshop Items } \\
\text { Harness/saddle parts } \\
\text { Tools } \\
\text { Wire } \\
\text { Clothing } \\
\text { Buttons } \\
\text { Buckle } \\
\text { Shoe parts } \\
\text { Stocking fastener } \\
\text { Construction Items } \\
\text { Brick } \\
\text { Building hardware } \\
\text { Carbon rods } \\
\text { Ceramic insulators } \\
\text { Cut nails } \\
\text { Electric fixture } \\
\text { Hardware } \\
\text { Heavy rods } \\
\text { Pipe and fittings } \\
\text { Window glass } \\
\text { Window screen } \\
\text { Wire nails } \\
\text { Household Items } \\
\text { Ceramic brazier } \\
\text { Flower pot } \\
\text { Furniture hardware } \\
\text { Lamp parts } \\
\text { Kitchen/Dining Items } \\
\text { Bone } \\
\text { Bottle caps } \\
\text { Crown caps } \\
\text { Glass stoppers } \\
\text { Metal screw caps }\end{array}$ & $\begin{array}{r}3 \\
3 \\
7 \\
3 \\
13 \\
5 \\
1 \\
2 \\
1 \\
2 \\
3 \\
3 \\
2 \\
6 \\
1 \\
5 \\
2 \\
5 \\
22 \\
2 \\
37 \\
1 \\
11 \\
1 \\
5 \\
52 \\
3 \\
2 \\
2\end{array}$ & $\begin{array}{c}\text { Ceramics } \\
\text { Decorated whitewares } \\
\text { Banded slip } \\
\text { Cut sponge } \\
\text { Over-glazed decorated } \\
\text { Painted } \\
\text { Transfer } \\
\text { Lead-glazed ware } \\
\text { Plain-colored ware } \\
\text { Porcelain } \\
\text { Stoneware } \\
\text { Tin-glazed ware } \\
\text { Guanajuato } \\
\text { Undecorated whiteware } \\
\text { Glass container fragments } \\
\text { Goblets } \\
\text { Pressed glass } \\
\text { Shell } \\
\text { Tin can scrap fragments } \\
\text { Tumblers } \\
\text { Personal Items } \\
\text { Ivory comb fragment } \\
\text { Kaolin pipe stem } \\
\text { 24-36 inches } \\
\text { Arms } \\
\text { Shotgun cartridge } \\
\text { Construction Items } \\
\text { Brick/tile } \\
\text { Building hardware } \\
\text { Ceramic insulators } \\
\text { Cut nails } \\
\text { Plaster } \\
\text { Window glass } \\
\text { Wire nails }\end{array}$ & $\begin{array}{r}1 \\
1 \\
8 \\
5 \\
23 \\
15 \\
2 \\
46 \\
41 \\
1 \\
91 \\
197 \\
2 \\
2 \\
2 \\
34 \\
2 \\
1 \\
1\end{array}$ \\
\hline
\end{tabular}


TABLE 5. (continued)

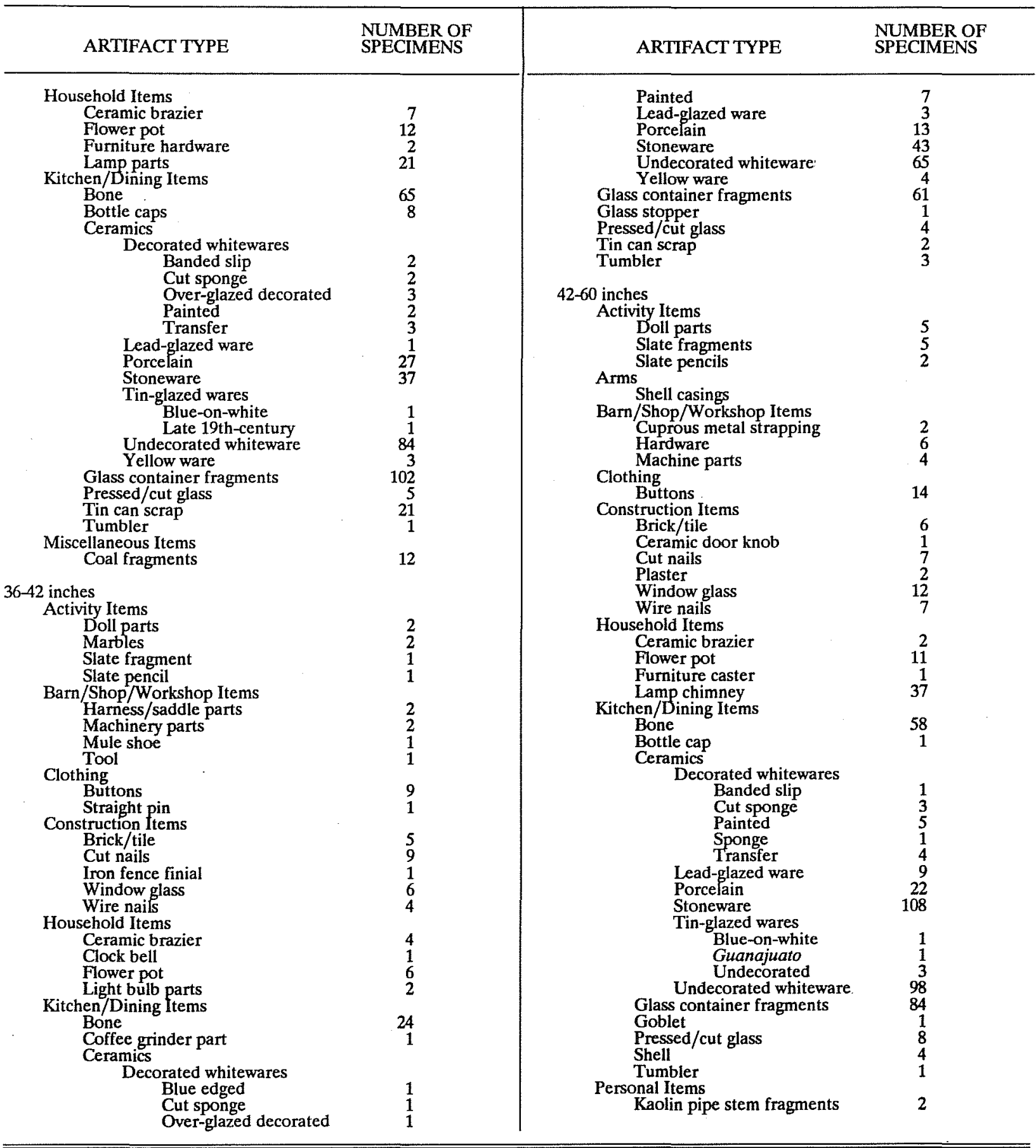


TABLE 6. TYPES OF SHERDS AND MAKER'S MARKS

FROM THE SAN PEDRO ACEQUIA (41 BX 337)

a, provenience of sherds of same pattern

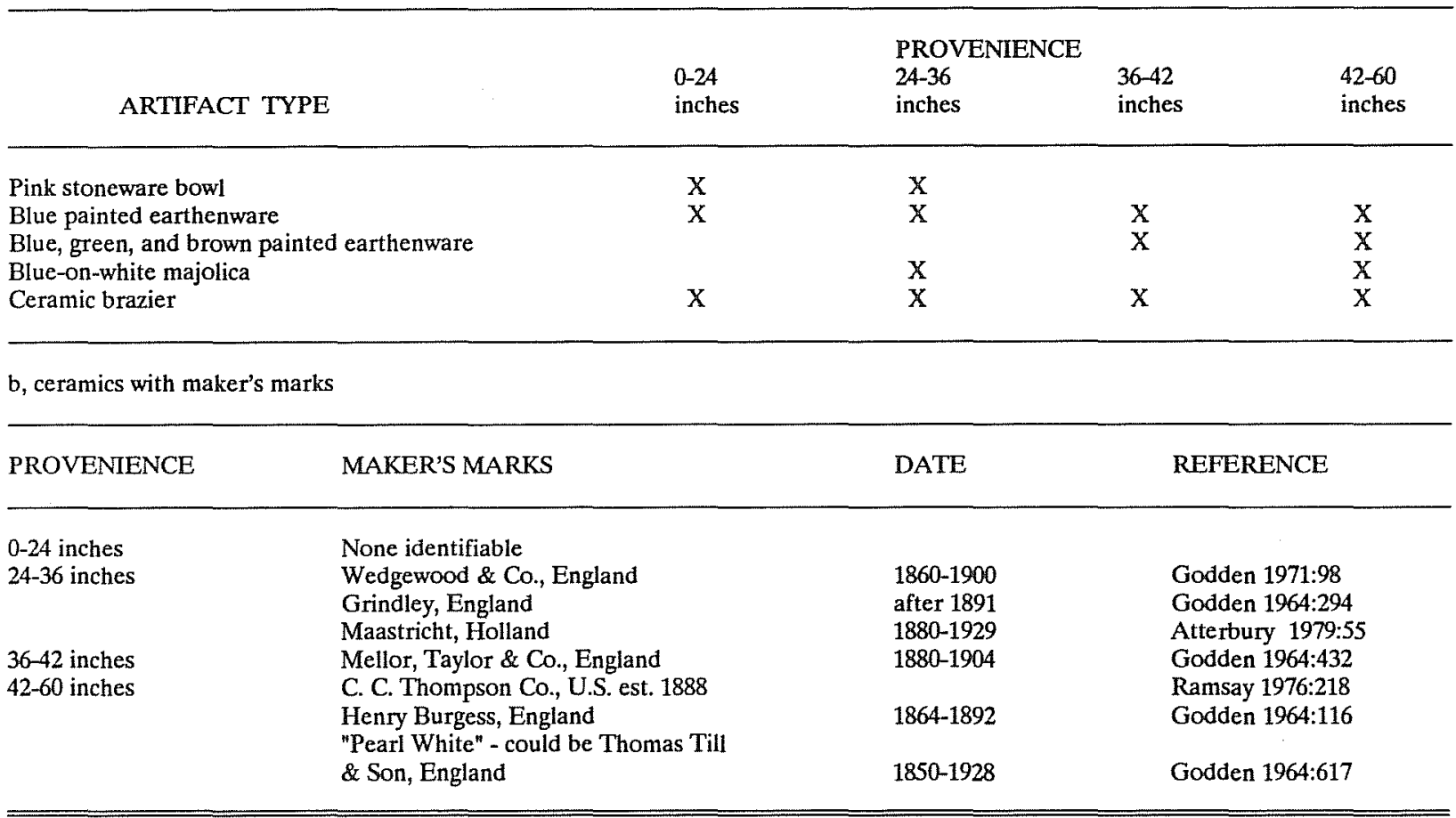

\section{Summary}

The tested section of the San Pedro acequia contained a variety of late 19 th-century and early 20 th-century artifacts, the result of trash dumping after the water to the ditch was shut off in 1906 . It was a surprise to also find at the bottom of the ditch fragments of 18th-century Mexican-made majolica and lead-glazed vessels, indicating that the annual cleaning of the ditch may not have been as rigorous here as elsewhere in the city. It was not possible to relate the trash in the ditch fill to any one residence in the area. Only one wall of the acequia is still present in this section; the other apparently has been removed, perhaps for reuse of the stones.

Trenches 6 and 7 came down on heavy concrete slabs and were abandoned without any further work.

\section{CONCLUSIONS FOR PHASE I}

During Phase I work, three small residential lots were examined, and details of the construction of the buildings were recorded. It was found that artifacts in the vicinity of the structures generally reflected the time period in which they were occupied, and could be used to suggest or confirm dates of construction on the lot.

Foundations for the average type of "adobe" house of mid-19th-century San Antonio appear to have been built of shaped limestone set in mortar made of lime and sand. The foundations for most of these houses were laid up in setting trenches four to six inches wider on each side than the finished width of the foundation, instead of using the older Spanish/Mexican practice of tamping and puddling foundation stones into a trench the exact width of the intended foundation (Fox and Hester 1976:12, 22). Only one of the structures examined, the kitchen at 225 West Nueva Street, was built in the older way. 
Of these homesteads, it appears that the ones at 223 and 225 West Nueva Street (41 BX 334 and 41 BX 335) have sufficient undisturbed archaeological deposits to be eligible for nomination as State Archeological Landmarks on the basis that each in its own way is typical of an architectural style of a specific time period in San Antonio. Each would also be capable of producing information on lot layout and use, and on changing middle-class life styles from the mid-19th century to the early 20 th century.

\section{THE INTERIM, THE 1970s}

After the paving of the south end of NCB 100 in the 1950s, a gradual increase had occurred in the amount of paved surface area on the block. This was partially a result of the gradual demolition of the small, older remodeled residential buildings and the construction of new, fireproof, reinforced concrete commercial buildings facing onto South Flores and Dolorosa Streets. As the demand for additional parking space continued to grow in the 1970 s, eventually these newer buildings were demolished, and their lots were paved. By 1979, only four buildings were left standing on the entire block.

\section{PHASE II}

In July 1979, the county demolished the remaining four buildings on the north end of NCB 100 . The most prominent of these was the two-story, cut stone Luetcke-Herald Building on Lot 3 (see Figs. 2, 3, and 4), the facade of which had been extensively modified. The demolition was monitored by Harvey P. Smith, Jr., a registered architect and staff member of the CAR. The intent of the monitoring was to determine whether any of the buildings had been built around portions of 18th-century structures, or if traces of earlier buildings or artifact deposits might be observed in the ground as the structures were removed.

The buildings were razed to ground level, after which the entire remaining area of the lot was paved with asphalt for parking. Smith documented the demolition process with black and white photographs and color slides. He noted no evidence of earlier buildings or trash deposits in the area that was cleared.

\section{PHASE III}

In August 1986, CAR archaeologists returned to the northeast corner of NCB 100 to determine the state of preservation of the San Pedro acequia (41 BX 337) and to determine if further work would be warranted in connection with the examination of traces of the Salinas-Barrera and de la Garza houses (41 BX 647).

A period of one week (August 25 to 29) was spent on test excavations by an archaeological crew consisting of two graduate students and a number of student volunteers. The crew worked under the supervision of project director Anne Fox and field supervisor Bruce Ellis. Four trenches (A, B, C, and D in Fig. 10) were excavated east to west across the area.

\section{TRENCH A}

Trench A was located $2.7 \mathrm{~m}$ (8.7 feet) south of the inside edge of the sidewalk along Dolorosa Street and extended from the inside edge of the sidewalk along South Main Avenue to a point $18 \mathrm{~m}$ ( 59.2 feet) to the west (Fig. 10). It was extended well to the west of the estimated location of the acequia in order to be positive in our identification of what was found. Stratification within this trench (and generally throughout the study area) was found to be as follows (see Fig. 11,a):

Asphalt parking lot material

Level 1 - reddish tan (5 YR 6/6) gravel fill, sterile 


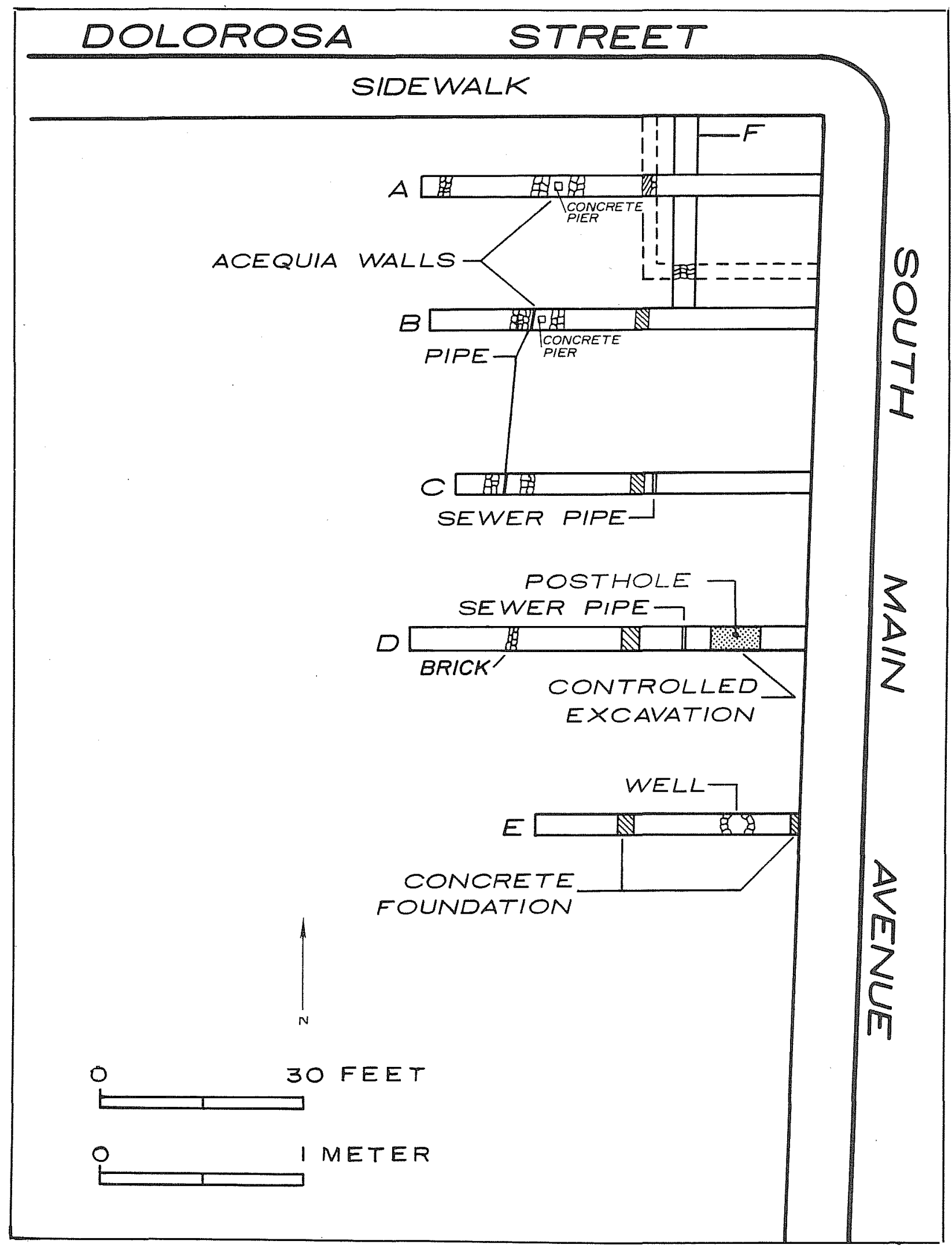

Figure 10. Phases III and IV Trenches. Trenches A-D were begun during Phase III, and Trenches B-D were continued during Phase IV; Trenches $\mathrm{E}$ and $\mathrm{F}$ were excavated during Phase IV. 

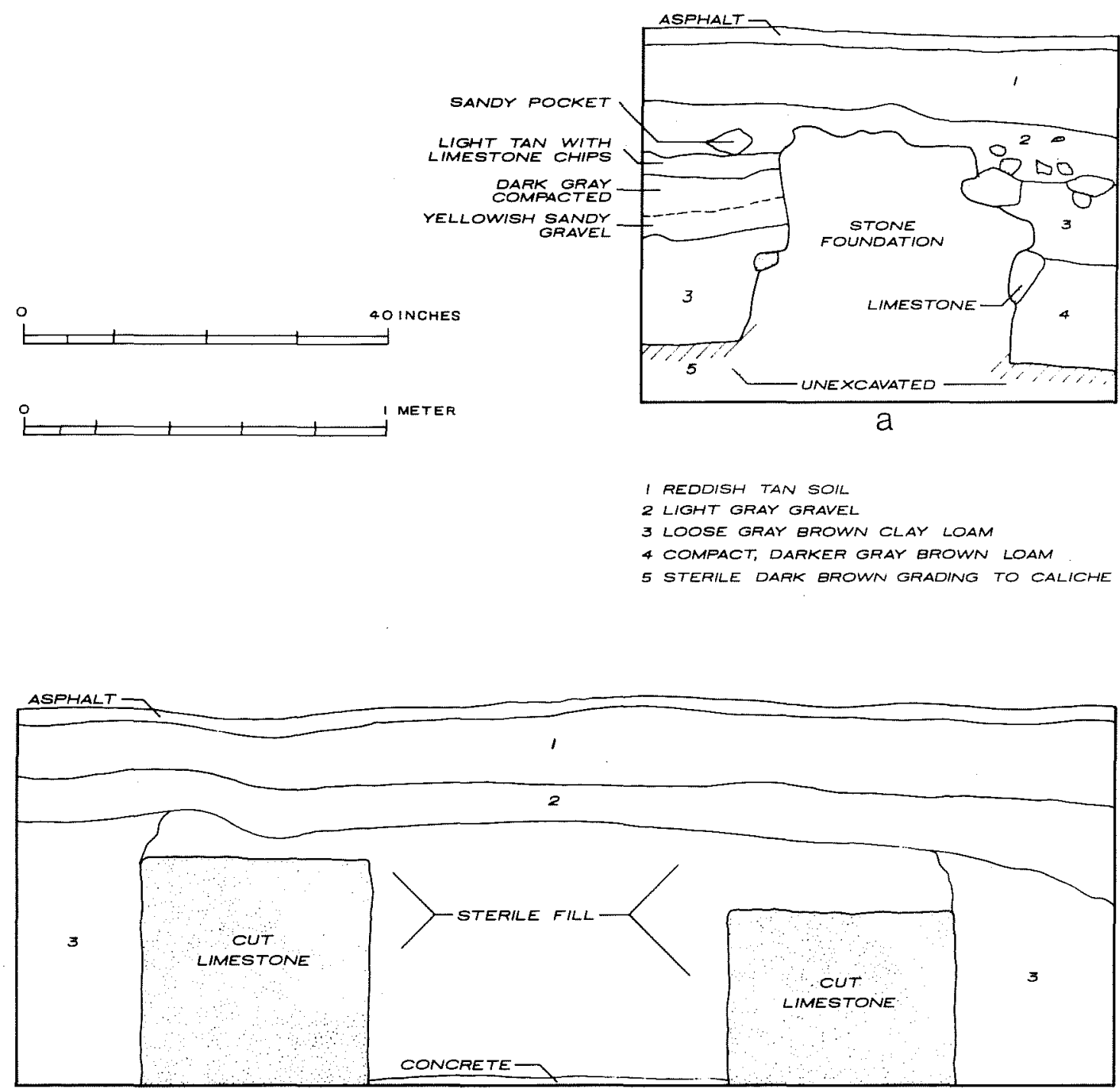

b

月 REINFORCING ROD

A CONCRETE

a AMORPHOUS CONCRETE

C DARK GRAY FILL WITH CHARCOAL AND SMALL GRAVEL IN LIGHTER MATRIX

- fILl with charcoal, bone aNd medium ROCKS; COMPACTED AND CLAYEY

E COMPACTED GRAVELLY FILL WITH SOME CONCRETE

F DARK GRAY COMPACTED MATRIX

G LOOSE MATRIX, LOW IN ARTIFACTUAL MATERIAL

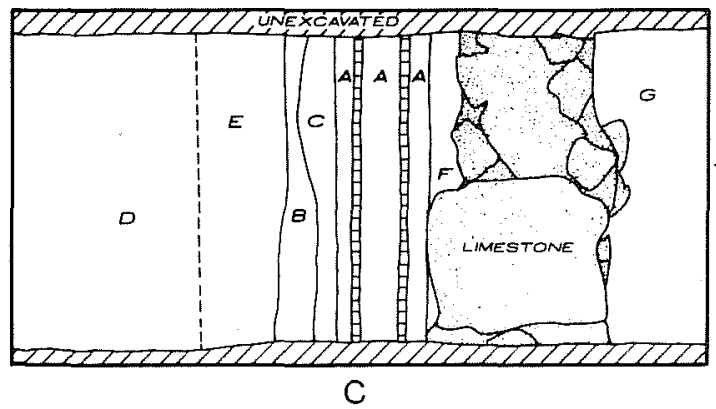

Figure 11. Features in Trench A. a, profile of south wall at west end of trench; $b$, profile of south wall at acequia; c, plan of trench at west wall of Salinas-Barrera house. 
Level 2 - light gray (10 YR 7/1) gravel fill containing demolition materials and a few 19th-century artifacts

Level 3 - loose gray brown (5 YR 6/1) clay loam containing 18th-century and some early 19th-century artifacts

Level 4 - compact, darker gray brown (4 YR 3/1) clay loam containing fewer 18th-century artifacts

Level 5 - sterile dark brown (10 YR 2/2) clay loam grading to caliche

Backhoe excavation of Trench A revealed that the construction and later demolition of a 20th-century building with reinforced concrete foundations had severely impacted the area. The de la Garza house foundation is believed to be located too far east to be included in the trench, and probably was removed during the construction of Main Avenue through the area. The east foundation wall of the Salinas-Barrera house was probably taken out during the construction of the later building on the site.

A similar situation happened in the case of the west wall of the Salinas-Barrera house. However, in this instance the concrete footing was found to have been dug into the remains of the stone foundation without completely removing it (Fig. 11,c). This fortunate circumstance allowed us to identify and locate the line of the house's west wall. Excavations to expose and examine this foundation were designated Unit A3. Artifacts (Table $7, \mathrm{e})$ recovered can be dated primarily to the late 18th century, along with a few representative materials from the demolition of the 20 th-century building.

The next structure encountered in excavating Trench A was a pair of parallel cut stone walls, each $64 \mathrm{~cm}(25$ inches) wide and about $120 \mathrm{~cm}$ (38 inches) apart that were recognized as the San Pedro acequia. This area was designated Unit A2. The acequia had a reinforced concrete pier in its center from a later building, and a concrete bottom. It was filled to the tops of the walls with tan sand containing no artifacts (Fig. 11,b). Artifacts (Table 7,d) recovered during the cleaning of Unit A2 include a range of 18th-century to 20th-century materials.

At the eastern end of Trench A, a stone foundation wall built of shaped limestone rocks set in sandy loam mortar was found. Designated Unit A1, deposits in this area were excavated by stratigraphic levels and screened through $1 / 4$-inch mesh screen.

Levels encountered were generally as previously described for the entire area. Artifacts (Table 7,a,b) recovered from the east side of the wall are somewhat mixed in date due to confused stratigraphy (Fig. 10,a) in this area from a later disturbance. Artifacts from the west side (Table 7,c) indicate a relatively undisturbed situation there.

\section{TRENCH B}

The location of the acequia in Trench $B$ was projected from Trench A, and the immediate area was excavated. Artifacts from Levels 2 and 3 (Table 8,a,b) indicated some mixing of deposits in the area. An intrusive sandy clay containing few artifacts (Table 8,c) filled most of the acequia. A sterile layer of dark brown clay covered the concrete bottom of the ditch. An iron pipe, partially removed by the backhoe, extended south within the line of the acequia.

\section{TRENCH C}

As in Trench B, work in this trench was concentrated on exposing and recording the acequia. The overburden was removed by the backhoe to the top of the acequia walls, and Level 2 deposits were also removed and discarded. Excavation was then limited to the interior of the acequia. Stratigraphic Levels $3 a$ through 5 were removed (Fig. 12,a), and artifacts were recovered as they were encountered in each level. 
TABLE 7. ARTIFACTS FROM TRENCH A, PHASE III

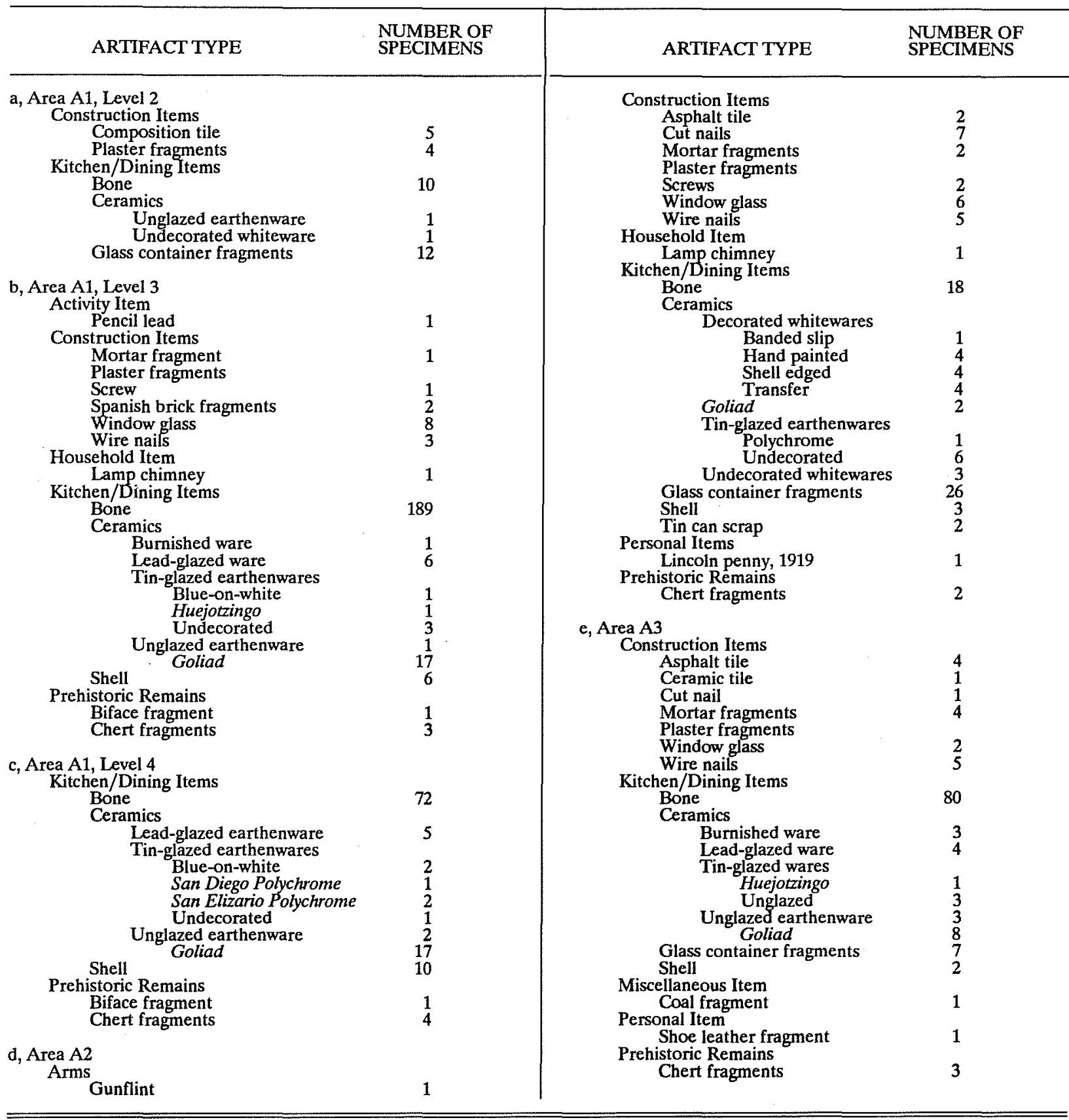


TABLE 8. ARTIFACTS FROM TRENCH B, PHASE III

\begin{tabular}{|c|c|c|c|}
\hline ARTIFACT TYPE & $\begin{array}{l}\text { NUMBER OF } \\
\text { SPECIMENS }\end{array}$ & ARTIFACT TYPE & $\begin{array}{l}\text { NUMBER OF } \\
\text { SPECIMENS }\end{array}$ \\
\hline $\begin{array}{l}\text { a, Level } 2 \text { Itivity Item } \\
\text { Marble } \\
\text { Construction Items } \\
\text { Asphalt tile } \\
\text { Ceramic tile } \\
\text { Cut nails } \\
\text { Mortar fragments } \\
\text { Plaster fragments } \\
\text { Screws } \\
\text { Window glass } \\
\text { Wire } \\
\text { Household Item } \\
\text { Flower pot } \\
\text { Kitchen/Dining Items } \\
\text { Animal bone } \\
\text { Ceramics } \\
\text { Decorated whitewares } \\
\text { Banded slip } \\
\text { Hand painted } \\
\text { Shell edged } \\
\text { Sponge } \\
\text { Transfer } \\
\text { Goliad } \\
\text { Lead-glazed ware } \\
\text { Tin-glazed wares } \\
\text { San Elizario Polychrome } \\
\text { Undecorated } \\
\text { Porcelain } \\
\text { Stoneware } \\
\text { Undecorated whiteware } \\
\text { Glass container fragments } \\
\text { Shell } \\
\text { Construction Items } \\
\text { Brick fragment } \\
\text { Ceramic pipe } \\
\text { Cut nails } \\
\text { Mortar fragment }\end{array}$ & $\begin{array}{r}2 \\
4 \\
3 \\
2 \\
4 \\
2 \\
9 \\
1 \\
1 \\
4 \\
4 \\
1 \\
1 \\
158 \\
3\end{array}$ & $\begin{array}{l}\text { Plaster fragments } \\
\text { Window glass } \\
\text { Wire nails } \\
\text { Household Items } \\
\text { Lamp chimney } \\
\text { Kitchen/Dining Items } \\
\text { Bone } \\
\text { Ceramics } \\
\text { Burnished ware } \\
\text { Decorated whitewares } \\
\text { Banded slip } \\
\text { Transfer } \\
\text { Lusterware } \\
\text { Porcelain } \\
\text { Tin-glazed ware } \\
\text { Gan Elizario Polychron } \\
\text { Stoneware bottle } \\
\text { Tin can scrap fragments } \\
\text { Coal fragments } \\
\text { Miscellaneous Items } \\
\text { c, acequia fill } \\
\text { Construction Items } \\
\text { Plaster fragment } \\
\text { Rolled metal tube } \\
\text { Window glass } \\
\text { Wire } \\
\text { Wire nail } \\
\text { Household Item } \\
\text { Lamp chimney } \\
\text { Kitchen/Dining Items } \\
\text { Ceramics } \\
\text { Undecorated whiteware } \\
\text { Cooking pan fragment } \\
\text { Glass container fragments }\end{array}$ & $\begin{array}{r}4 \\
40 \\
20 \\
4 \\
4 \\
37 \\
1 \\
1 \\
1 \\
2 \\
1 \\
2 \\
\text { me } \\
152 \\
8\end{array}$ \\
\hline
\end{tabular}

The artifacts from Level 3a (Table 9,a), a clay soil that capped the acequia fill, were a mixture of demolition debris with a few cultural items. The main body of the sandy clay fill in Level 4 (Table 9,b) contained a large assortment of 18th- and 19th-centuries household materials and personal items and a smaller percentage of construction materials. Few artifacts were found in the upper part of Level 5 (Table 9,c), which quickly became sterile gray clay.

\section{TRENCH D}

In Trench $\mathrm{D}$, the acequia had been completely eliminated except for a small pile of limestone at the approximate location of the west wall. In place of the east acequia wall, a red brick foundation had been built (Fig. 12,b). Due to the obvious disturbance on both sides of this wall, and a lack of visible stratification, the excavations were continued without a break from the bottom of the backhoe trench at the contact between Levels 2 and 3 to a depth of $110 \mathrm{~cm}$ (42.9 inches). Artifacts from east and west of the wall were bagged separately (Table 10). A shovel test was excavated at the east end of the trench to determine the depth of the deposits.

The artifacts recovered to the east of the brick foundation were not out of character with what had been found in Level 3 elsewhere on the lot. The intensity and assortment of early and late 19th-century materials from the west side of the wall suggest trash deposition over quite a period of time. However, a study of the profile drawn after excavation was completed suggests that the later materials probably came from the upper 
I REDDISH TAN GRAVEL

2 LIGHT GRAY GRAVEL

3 LOOSE GRAY EROWN CLAY LOAM

4 COMPACT, DARKER GRAY EROWN CLAY

5 STERILE DARK GROWN GRADING TO CALICHE
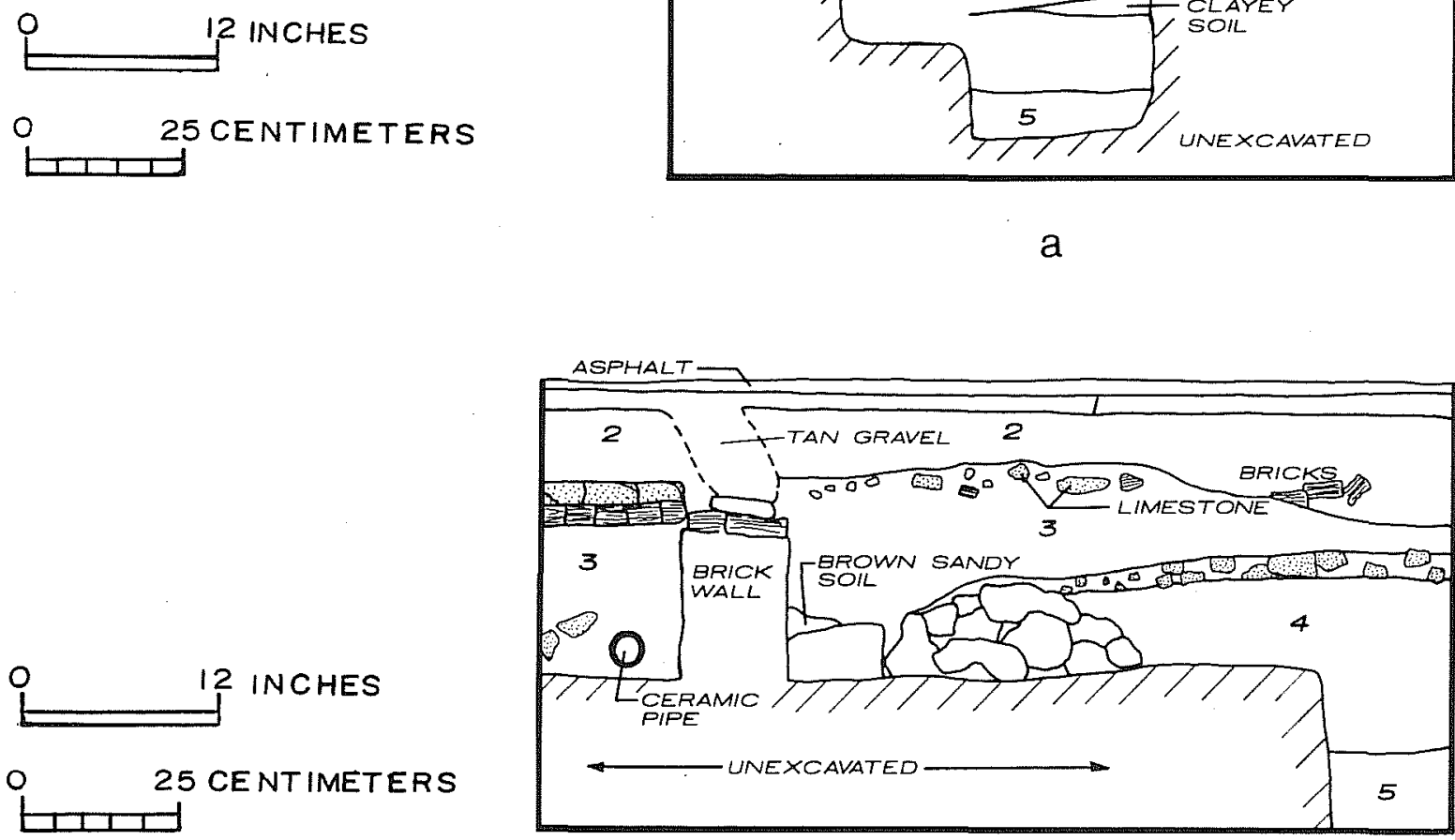

b

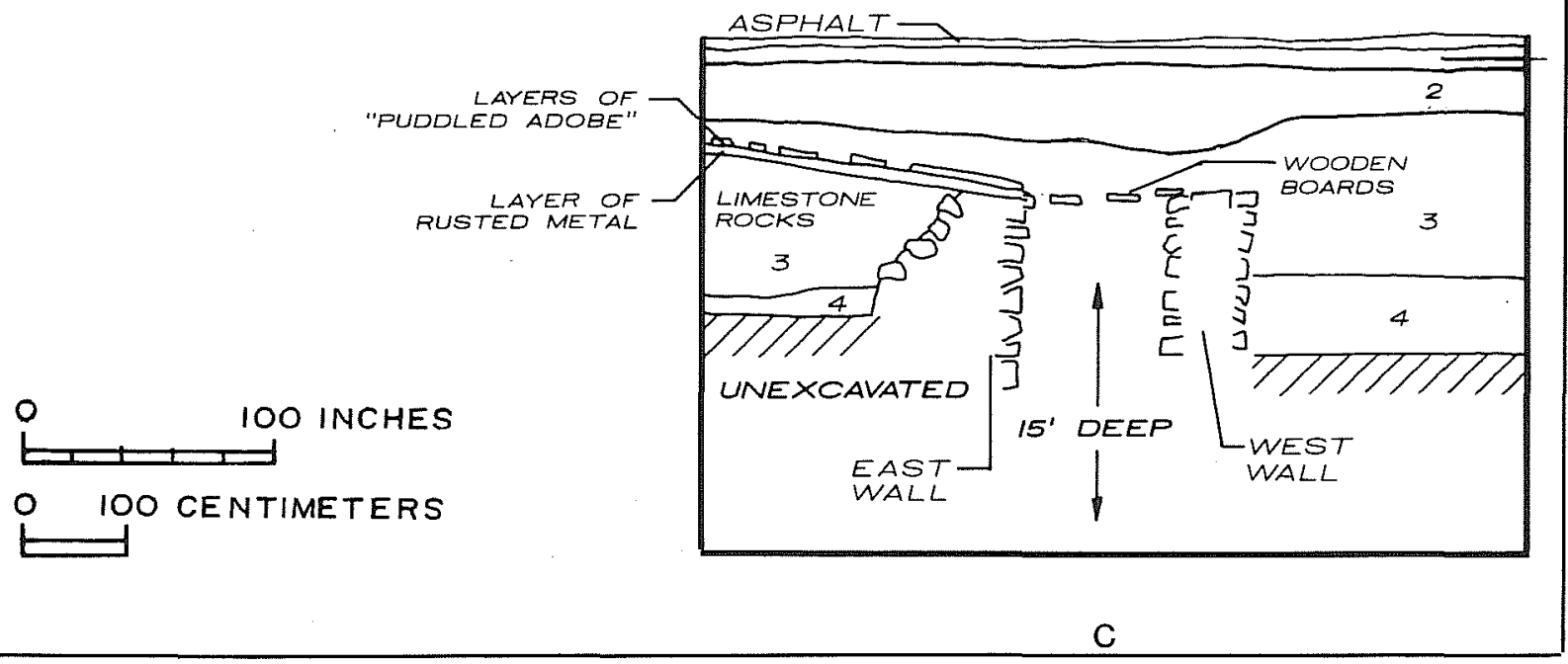

Figure 12. Features in Trenches $C, D$ (Phase III), and $E$ (Phase IV). a, section through acequia in Trench C; $\mathrm{b}$, section through brick foundation in Trench D; c, section through well in Trench $\mathrm{E}$. 
TABLE 9. ARTIFACTS FROM TRENCH C, PHASE III

\begin{tabular}{|c|c|c|c|}
\hline ARTIFACT TYPE & $\begin{array}{l}\text { NUMBER OF } \\
\text { SPECIMENS }\end{array}$ & ARTIFACT TYPE & $\begin{array}{l}\text { NUMBER OF } \\
\text { SPECIMENS }\end{array}$ \\
\hline 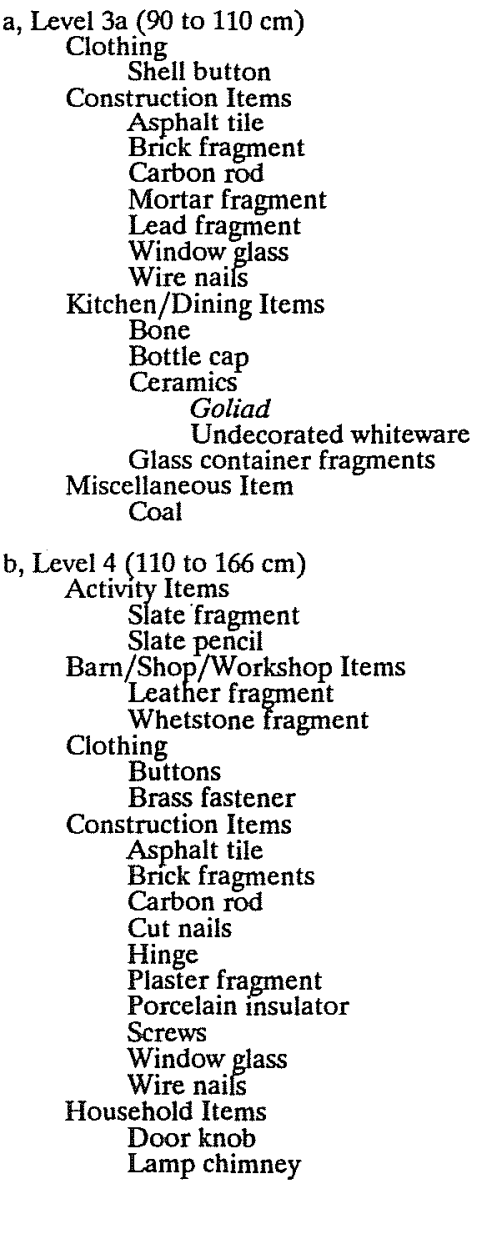 & $\begin{array}{r}1 \\
1 \\
1 \\
1 \\
8 \\
1 \\
3 \\
2 \\
1 \\
3 \\
1 \\
1 \\
1 \\
4 \\
45 \\
66 \\
\\
1 \\
41\end{array}$ & 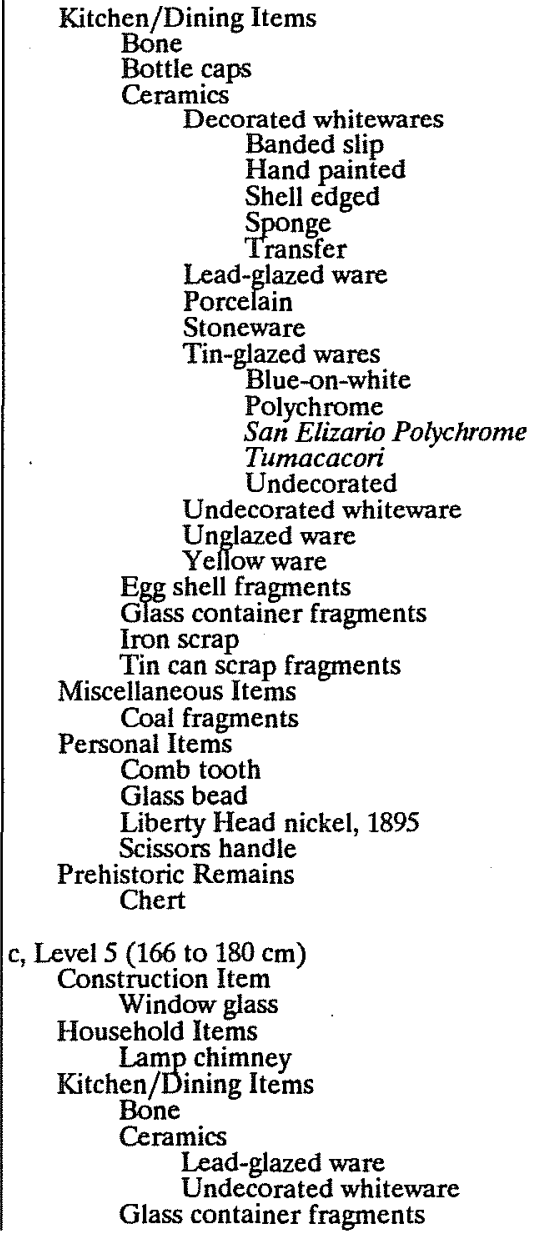 & $\begin{array}{r}1 \\
8 \\
1 \\
1 \\
6 \\
19 \\
3 \\
3 \\
16 \\
4 \\
3 \\
2 \\
16 \\
16 \\
9 \\
6 \\
155 \\
5\end{array}$ \\
\hline
\end{tabular}

level and consisted of discarded trash used to fill the acequia bed, and later spread over the area when the brick foundation was built, demolishing the acequia. The earlier materials probably came from the lower level that represented the soils below this demolition that correspond to Levels 3 and 4 elsewhere on the lot. There was a surprising lack of 18th-century material in this deposit, perhaps because of the growing distance from the main center of occupation on Dolorosa Street.

\section{SUMMARY OF PHASE III TESTING}

Phase III testing was successful in finding the east wall of the Salinas-Barrera house at the expected location and in finding artifacts such as Goliad ware and 18th-century tin-glazed ceramic sherds in the immediate vicinity of the foundation that suggest an 18th-century date of occupation. Additional early sherds (San Elizario and San Diego patterns, see "Artifact Analysis" section) in Units A2 and A1 confirm the fact that this land could have been occupied from at least the 1770 s.

The acequia was also located and found to be in sound condition for approximately $15 \mathrm{~m}$ (50 feet) south of the sidewalk on Dolorosa Street. The width of the channel (115 cm or 45 inches) and the construction of the stone walls lining it have now been recorded. 
TABLE 10. ARTIFACTS FROM TRENCH D, PHASE III

\begin{tabular}{|c|c|c|c|}
\hline ARTIFACT TYPE & $\begin{array}{l}\text { NUMBER OF } \\
\text { SPECIMENS }\end{array}$ & ARTIFACT TYPE & $\begin{array}{l}\text { JUMBER OF } \\
\text { PECIMENS }\end{array}$ \\
\hline $\begin{array}{l}\text { a, east of wall, all levels } \\
\text { Barn/Shop/Worksop Items } \\
\text { Shoe repair form } \\
\text { Wire } \\
\text { Construction Items } \\
\text { Carbon rods } \\
\text { Window glass } \\
\text { Wire nails } \\
\text { Household Item } \\
\text { Flower pot } \\
\text { Kitchen/Dining Items } \\
\text { Bone } \\
\text { Bottle cap } \\
\text { Ceramics } \\
\text { Decorated whitewares } \\
\text { Transfer } \\
\text { Porcelain } \\
\text { Undecorated whiteware } \\
\text { Glass container fragments } \\
\text { Oyster shell } \\
\text { Tin can scrap fragments } \\
\text { b, west of wall, all levels } \\
\text { Activity Items } \\
\text { Doll's eye } \\
\text { Marbles } \\
\text { Slate pencils } \\
\text { Arms } \\
\text { Shell casing, .58-.62 caliber } \\
\text { Barn/Shop/Workshop Items } \\
\text { Carbon rods } \\
\text { Flywheel } \\
\text { Leather rivet } \\
\text { Miscellaneous wire fragments } \\
\text { Clothing } \\
\text { Buttons } \\
\text { Scissors handle } \\
\text { Construction Items } \\
\text { Asphalt tile } \\
\text { Brick fragments } \\
\text { Ceramic tile } \\
\text { Cut nails }\end{array}$ & $\begin{array}{r}1 \\
2 \\
4 \\
37 \\
12 \\
1 \\
26 \\
1\end{array}$ & $\begin{array}{l}\text { Gas light fragment } \\
\text { Lead rragments } \\
\text { Miscellaneous metal fragments } \\
\text { Mortar } \\
\text { Plaster } \\
\text { Threaded pipe coupling } \\
\text { Window glass } \\
\text { Wire nails } \\
\text { Household Items } \\
\text { Brass drawer pull } \\
\text { Clock hand } \\
\text { Lamp chimney } \\
\text { Metal finial } \\
\text { Kitchen/Dining Items } \\
\text { Bone } \\
\text { Bottle caps } \\
\text { Ceramics } \\
\text { Decorated whitewares } \\
\text { Banded slip } \\
\text { Hand painted } \\
\text { Shell edged } \\
\text { Sponge } \\
\text { Transfer } \\
\text { Lead-glazed wares } \\
\text { Porcelain } \\
\text { Undecorated tin-glazed ware } \\
\text { Undecorated whiteware } \\
\text { Yellowed ware } \\
\text { Glass container fragments } \\
\text { Iron scrap } \\
\text { Oyster shell } \\
\text { Silver-plated spoon } \\
\text { Tin can scrap fragments } \\
\text { Miscellaneous Items } \\
\text { Coal fragments } \\
\text { Quartz crystal } \\
\text { Personal Items } \\
\text { Oval eyeglass lens } \\
\text { Syringe tube } \\
\text { Token (1880-1900) } \\
\text { Prehistoric Remains } \\
\text { Chert fragments }\end{array}$ & $\begin{array}{r}9 \\
9 \\
1 \\
13 \\
1 \\
10 \\
21 \\
5 \\
168 \\
2 \\
3 \\
506 \\
10 \\
16 \\
1 \\
\end{array}$ \\
\hline
\end{tabular}

It also appeared that there might be a possibility of intact back yard deposits in the area immediately east of the acequia, behind the Salinas-Barrera house. The recommendation was therefore made that additional archaeological testing be done in this area.

\section{RECOMMENDATIONS FOR FURTHER WORK AFTER PHASE III}

The following recommendations were made to the Commissioners Court after studies had been completed on Phase III results. They were formulated in consultation with J. Barto Arnold III of the staff of the Texas Antiquities Committee.

1. A 50-foot-square area in the back yard of the Salinas-Barrera house should be tested to determine if any intact trash deposits survive that would tell us more about the occupants of the Salinas-Barrera house.

2. Funds should be allocated for the production of a final report on all phases of the investigation.

3. The remaining section of the acequia at the north end of the block is sufficiently intact to be used as part of a landscaping plan for the new building. 


\section{PHASE IV}

During the week of August 17 to 21, 1987, further test excavations were conducted on the northeast section of NCB 100, under the supervision of project director Anne Fox and field supervisor Bruce Ellis. The crew consisted of three graduate students and a number of volunteer workers.

The purpose of this phase of work was to examine and investigate the back yard of the historic structure that had occupied this corner of the block. The first step, as in other phases, was to lay out trenches and remove the asphalt and the underlying gravel and demolition fill with the use of a backhoe. Once this had been done, the intact cultural deposits could be excavated. This also was begun with a backhoe, but could be stopped and continued by hand as deemed necessary. The second step was to map and record all structural remains that were uncovered.

The back yards of historic Spanish/Mexican structures of the 18th and early 19th centuries are one of the most productive areas for artifact recovery due to the general practice of using pits and wells in this area for discarding trash (Clark and Juarez 1986; Folan et al. 1986). This practice apparently continued into the late 19th and early 20th centuries in San Antonio, as evidenced by the use of the acequia, located just to the west of the current area of concentration, for the dumping of trash after it went out of use (see "Phase I" section).

Five test trenches were established so that they cut across the back yard of the Salinas-Barrera house (Fig. 10), in hope of finding trash deposits related to the early occupation of this structure. The trenches began at the sidewalk on the east side of the block and extended west to the beginning point of the trenches from the previous year. Trenches B, C, and D, which would be extended from the previous year's excavations, were therefore given the same alphanumeric designations. Trenches $E$ and $F$ were new trenches.

\section{TRENCH B}

Test Trench B was located $8 \mathrm{~m}$ (26.3 feet) south of the inside edge of the Dolorosa Street sidewalk and extended $9 \mathrm{~m} \mathrm{(30}$ feet) to the west from the inside of the South Alamo Street sidewalk. This trench was placed so as to be only 3 to 5 feet behind the estimated location of the Salinas-Barrera house. This was in order to locate any outbuildings or trash pits that might have been placed directly to the rear of the main house. Excavations in this trench supported the fact that this area of the block had been heavily disturbed during later demolition and construction phases. No evidence of outbuildings was found.

The stratigraphy of this trench was composed of four basic levels (see description in "Phase III" section). The upper two levels appeared to be associated with parking lot construction and building demolition fill, with the lower two levels holding somewhat more intact cultural deposits.

The concrete footing for a 20th-century building was uncovered along the edge of the sidewalk, as found in Trench A in 1986. Another section of the footing was also exposed $7.6 \mathrm{~m}$ ( 25 feet) to the west in the trench. A wide variety of artifacts was recovered from this trench (Table 11). The artifacts include early blue-on-white 18th-century majolica, green 19th-century bottle glass, and modern white ceramic tile. Unfortunately, all of the artifacts found were in mixed or disturbed context, as in Trench A.

\section{TRENCH $\mathbb{C}$}

Test Trench $\mathrm{C}$ was located $15.5 \mathrm{~m}$ (52 feet) south of the Dolorosa Street sidewalk and extended $9.5 \mathrm{~m}$ ( 31 feet) to the west of the South Alamo Street sidewalk. This trench was situated $8 \mathrm{~m}$ (26 feet) south of Trench $\mathrm{B}$, and was also intended to locate the remains of any outbuildings or areas of artifact concentration. 
TABLE 11. ARTIFACTS FROM TRENCH B, LEVEL 3, PHASE IV

\begin{tabular}{|c|c|c|c|}
\hline ARTIFACT TYPE & $\begin{array}{l}\text { NUMBER OF } \\
\text { SPECIMENS }\end{array}$ & ARTIFACT TYPE & $\begin{array}{l}\text { NUMBER OF } \\
\text { SPECIMENS }\end{array}$ \\
\hline $\begin{array}{l}\text { Construction Items } \\
\text { Asphalt tile } \\
\text { Brick and tile } \\
\text { Ceramic insulator } \\
\text { Cut nails } \\
\text { Window glass } \\
\text { Wire nails } \\
\text { Kitchen/Dining Items } \\
\text { Bone } \\
\text { Ceramics } \\
\text { Decorated whiteware } \\
\text { Banded slip }\end{array}$ & $\begin{array}{r}2 \\
45 \\
1 \\
4 \\
15 \\
26 \\
\\
1\end{array}$ & $\begin{array}{l}\text { Tin-glazed ware } \\
\text { Blue-on-white } \\
\text { Undecorated whiteware } \\
\text { Unglazed earthenware } \\
\text { Goliad } \\
\text { Glass container fragments } \\
\text { Iron scrap } \\
\text { Personal Item } \\
\text { Buffalo nickel } \\
\text { Prehistoric Remains } \\
\text { Chert fragments }\end{array}$ & $\begin{array}{r}1 \\
7 \\
2 \\
15 \\
5 \\
1 \\
2\end{array}$ \\
\hline
\end{tabular}

The stratigraphy of Trench $C$ appeared to be similar but slightly different from that in Trench B, in that Level 3 went deeper, and therefore was wider and more extensive. The backhoe was used to remove sections of Level 3 from the trench to a separate location for screening, one from the east end and one from near the west end of the trench. Artifact quantities and variety were much the same, and the resulting collections were later combined (Table 12). Two soil samples were taken from Level 3 for later examination.

TABLE 12. ARTIFACTS FROM TRENCH C, LEVEL 3, PHASE IV

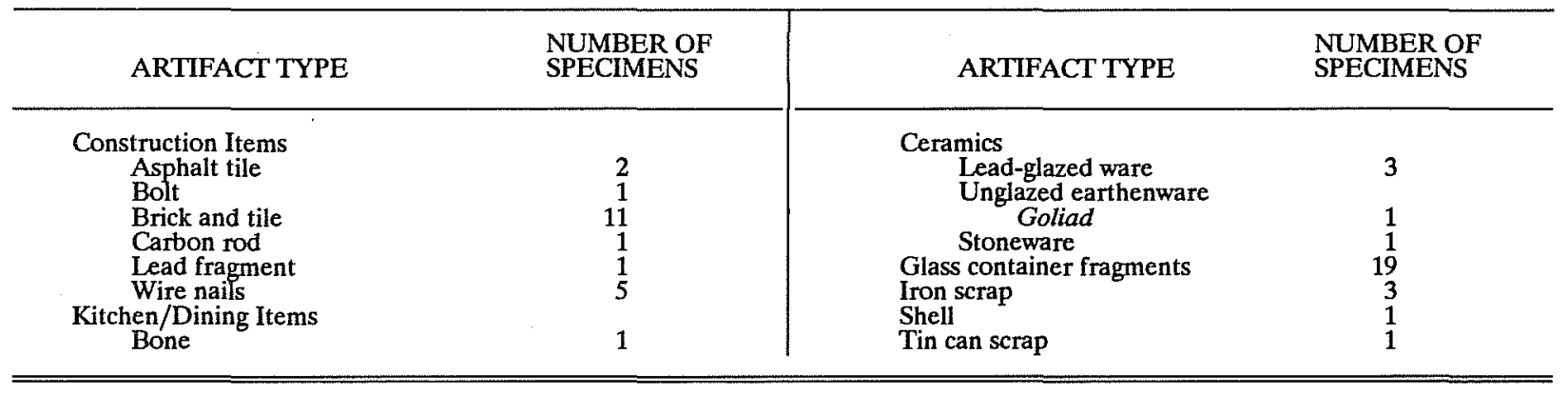

\section{TRENCH D}

Test Trench D was located $23 \mathrm{~m}$ (75.8 feet) south of the Dolorosa Street sidewalk and extended $10.5 \mathrm{~m}$ (34.6 feet) west of the South Alamo Street sidewalk. This trench was intended to locate the remains of any outbuildings or artifact concentrations that were located at a distance from the main structures. The stratigraphy of this trench is similar to that of Trench B. Artifacts recovered during general excavation of this trench were grouped under one provenience (Table 13).

A section of this trench was selected to be used for a controlled excavation to document the observed disturbance within Level 3. The unit measured $76 \mathrm{~cm} \mathrm{x} 2 \mathrm{~m}$ (28 inches $x 6.3 \mathrm{feet})$ and was excavated in arbitrary 10-cm layers. The excavations continued to a depth of $110 \mathrm{~cm}$ (43 inches). These excavations extended through stratigraphic Levels 3 and 4, the main artifact-bearing levels.

The first 10-cm excavation layer $(40$ to $50 \mathrm{~cm}$ ) was part of the Level 2 demolition deposits, which is somewhat reflected in the artifacts recovered (Table 14) and the layers of debris in the profile. The next four excavation layers $(50$ to $90 \mathrm{~cm}$ ) were within Level 3, and contained artifacts from throughout the 19th century. The upper $20 \mathrm{~cm}$ of this deposit seem to be a mixture of early and later material with no clear time-stratification. 
TABLE 13. ARTIFACTS FROM TRENCH D, LEVEL 3, PHASE IV

\begin{tabular}{|c|c|c|c|}
\hline ARTIFACT TYPE & $\begin{array}{l}\text { NUMBER OF } \\
\text { SPECIMENS }\end{array}$ & ARTIFACT TYPE & $\begin{array}{l}\text { NUMBER OF } \\
\text { SPECIMENS }\end{array}$ \\
\hline $\begin{array}{l}\text { Activity Item } \\
\text { Marble } \\
\text { Construction Items } \\
\text { Brick } \\
\text { Nails } \\
\text { Kitchen/Dining Items } \\
\text { Ceramics } \\
\text { Burnished ware } \\
\text { Decorated whitewares } \\
\text { Banded slip } \\
\text { Hand painted ware } \\
\text { Shell edged } \\
\text { Transfer }\end{array}$ & $\begin{array}{l}1 \\
1 \\
8 \\
1 \\
2\end{array}$ & $\begin{array}{l}\text { Lead-glazed ware } \\
\text { Tin-glazed wares } \\
\text { Polychrome } \\
\text { San Elizario Polychrome } \\
\text { Unglazed earthenware } \\
\text { Goliad } \\
\text { Undecorated whiteware } \\
\text { Stoneware } \\
\text { Glass container fragments } \\
\text { Glass bead }\end{array}$ & $\begin{array}{l}5 \\
1 \\
1 \\
1 \\
1 \\
1 \\
1 \\
5\end{array}$ \\
\hline
\end{tabular}

The lower $20 \mathrm{~cm}$ reflected an occupation ca. 1790 to 1840 or 1850, based on results of excavations at La Villita (Labadie 1986), slightly earlier than the upper $20 \mathrm{~cm}$ but still not clearly stratified. The bottom two excavation layers ( 90 to $110 \mathrm{~cm}$ ) were within Level 4 deposits and contained only Spanish/Mexican artifacts, which would push the upper occupation date of this stratum back before ca. 1830 when English ceramics first began to appear in quantity in San Antonio. An unexplained posthole was found in the Level 4 deposits (Fig. 10), which may have been related to some type of back yard activity. Level 4 contained no datable artifacts.

It is difficult to account for the absence of clear stratification and the comparative depth to which these deposits extend. Everyday yard trampling and disturbances and accretions from occasional floods could be contributing factors. However, the notorious shrink-swell character of this type of soil is probably responsible for much of the mixing of diagnostic artifacts, and for their depth within the soil formation. The same sort of deposits were found in Pit B in the back yard of the Spanish Governor's Palace (Fox 1977:9).

\section{TRENCH E}

Trench $\mathrm{E}$ was located $40.2 \mathrm{~m}$ (104 feet) south of the Dolorosa Street sidewalk and extended $9.5 \mathrm{~m}$ ( 31 feet) to the west from the South Alamo Street sidewalk. This trench was placed to locate any outbuildings or areas of artifactual concentration at the back of the lot. An accumulation of late 19th-century materials was found at the west end of the trench, similar to those found in Trench D the previous year. Otherwise, the artifacts were a general cross section of late 18th- and early 19th-centuries debris (Table 15).

An unfilled, stone-lined well was uncovered $46 \mathrm{~cm}$ ( $1.5 \mathrm{feet}$ ) east of the sidewalk and $70 \mathrm{~cm}$ ( 27 inches) below the surface of the parking lot (Fig. 12,c). There were wooden beams across the top of the well which held up a badly rusted sheet of iron and several different layers of deposits above, topped by a layer of what looked like puddled adobe. The well lining was constructed of cut and uncut limestone blocks. At least one of the stones contained a drill hole from the quarrying/splitting process. No signs of a construction trench for the well could be found during excavation. There were very few traces of mortar still left between the stones, although some remained around the top of the well. Embedded in this mortar was a sherd of Monterey Polychrome majolica, a ceramic pattern dating from the late 18 th century or very early 19 th century. This suggests that the well could have been built during the first quarter of the 19 th century by Francisco Manuel Salinas when he lived in a jacal at the front of the lot. The rather casual stonework in the well lining is not at all similar to the construction observed in the foundation of the later 19th-century stone house on this lot. The well measured $92 \mathrm{~cm}$ ( $3 \mathrm{feet}$ ) across the outside, with an inside diameter of $72 \mathrm{~cm}$ ( 28 inches). The depth of the well, measured from the present top of the lining, was $4.6 \mathrm{~m}$ ( 15.2 feet) to the top of the rocks that had fallen into the cavity, probably the remains of the top courses of the well lining. No attempt was made to examine or excavate the deposits at the bottom of this structure for safety reasons. However, an agreement was made with the county that CAR personnel would be called to examine the lower part of the well when 
TABLE 14. ARTIFACTS FROM TRENCH D, CONTROLLED EXCAVATION, PHASE IV

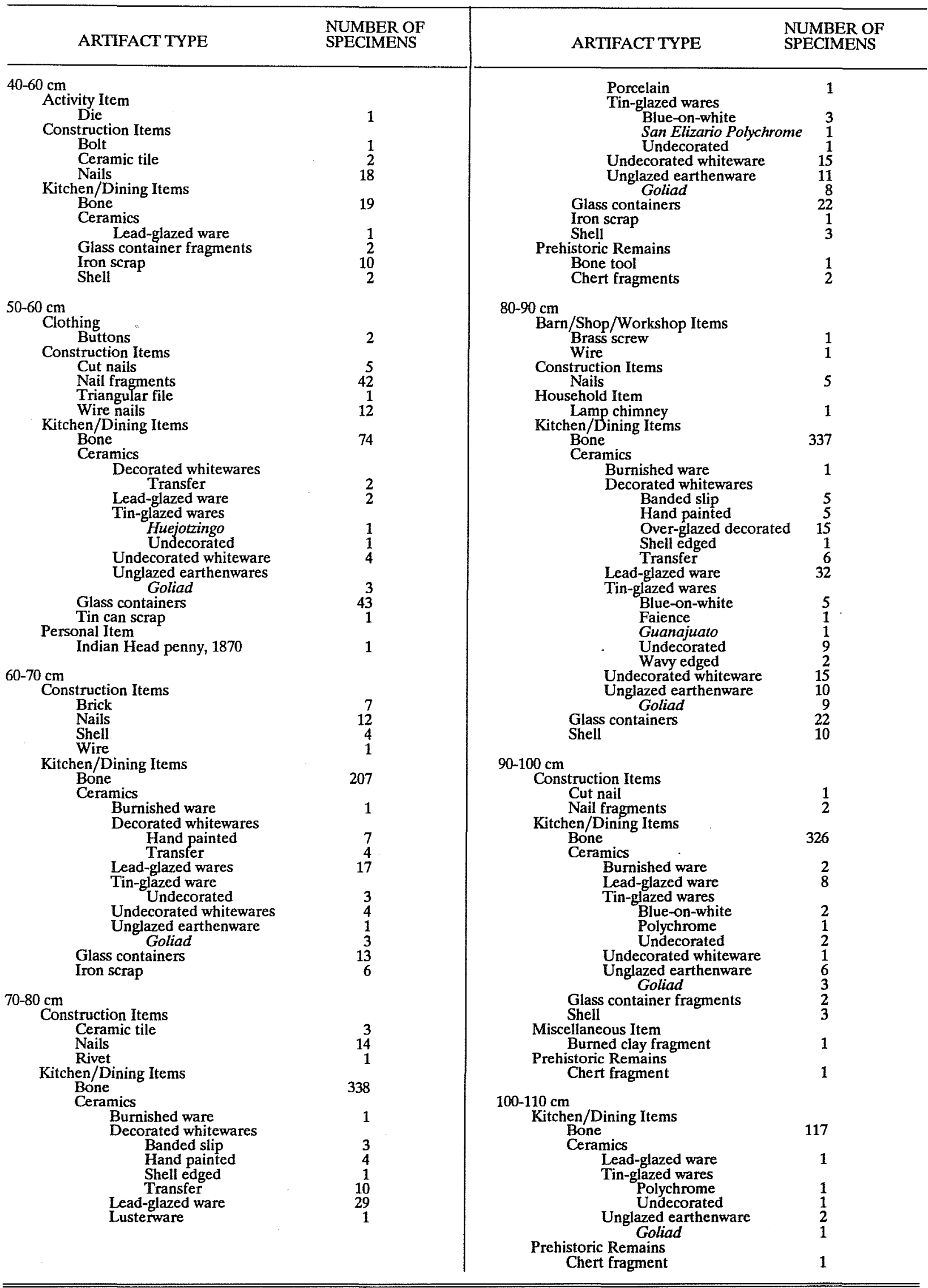


TABLE 15. ARTIFACTS FROM TRENCH E, LEVEL 3, PHASE IV

\begin{tabular}{|c|c|c|c|}
\hline ARTIFACT TYPE & $\begin{array}{l}\text { NUMBER OF } \\
\text { SPECIMENS }\end{array}$ & ARTIFACT TYPE & $\begin{array}{l}\text { NUMBER OF } \\
\text { SPECIMENS }\end{array}$ \\
\hline $\begin{array}{l}\text { Construction Items } \\
\text { Brick } \\
\text { Carbon rods } \\
\text { Ceramic insulators } \\
\text { Ceramic tile } \\
\text { Nails } \\
\text { Window glass } \\
\text { Kitchen/Dining Items } \\
\text { Ceramics } \\
\text { Decorated whitewares } \\
\text { Banded slip } \\
\text { Hand painted } \\
\text { Shell edged } \\
\text { Sponge } \\
\text { Transfer }\end{array}$ & $\begin{array}{r}5 \\
2 \\
2 \\
2 \\
32 \\
1\end{array}$ & $\begin{array}{l}\text { Tin-glazed wares } \\
\text { Blue-on-white } \\
\text { Monterey Polychrome } \\
\text { Polychrome } \\
\text { San Elizario Polychrome } \\
\text { Unglazed earthenware } \\
\text { Goliad } \\
\text { Stoneware } \\
\text { Glass containers } \\
\text { Iron scrap } \\
\text { Shell } \\
\text { Oyster }\end{array}$ & $\begin{array}{r}2 \\
1 \\
1 \\
1 \\
1 \\
1 \\
5 \\
237 \\
7 \\
7\end{array}$ \\
\hline
\end{tabular}

the basement for the new building was excavated. The well cavity was then immediately filled with sand both to preserve it during later construction activities and for the safety of the crew and the public.

When excavation for the Justice Center building reached this area, the senior author was called back to the site to monitor the removal of the well. One pass of the bulldozer was enough to cause the total collapse of the well lining, so fragile was its condition. At the level of the floor of the new excavation, it was apparent that the sand fill still continued to a considerable depth. The decision was made that any information that might be recovered from further excavation of the well would not be worth the dangerous operation required to excavate within it.

\section{TRENCH $\mathbb{F}$}

Test Trench F was located $6.4 \mathrm{~m}$ (21 feet) west of the South Alamo Street sidewalk, and extended north-south between the edge of the sidewalk on Dolorosa Street and Trench B. This trench was positioned in an attempt to locate the south and north walls of the Salinas-Barrera house. A stone foundation uncovered $5.4 \mathrm{~m}(17$ feet 9 inches) from the sidewalk was determined to be the south wall. The top of the foundation was exposed about $41 \mathrm{~cm}$ (16 inches) below the surface of the lot, and it extended to approximately $1 \mathrm{~m}$ (39 inches) below the surface. Large cut limestone blocks topped the foundation with smaller, more irregularly shaped stones toward the bottom. A fine-grained moist and friable lime and sand mortar was still visible between the stones and smeared over part of the outer surface of the foundation on either side.

Only a few artifacts (Table 16) were recovered from the wall trench on either side of this foundation. These included bone, glass, a couple of lead-glazed sherds, and a sherd each of Goliad ware and Puebla Polychrome majolica. The latter is the earliest datable artifact recovered from this site. A few sherds of this pattern have been found at the Spanish Governor's Palace on Military Plaza (Fox 1977:14) and beneath the San Fernando Cathedral (Fox, Scurlock, and Clark 1977:Fig. 17, 1,0). These have been attributed to the very first settlement of the plaza, ca. 1720 (Fox 1977:10).

TABLE 16. ARTIFACTS FROM TRENCH F, PHASE IV

\begin{tabular}{|c|c|c|c|}
\hline ARTIFACT TYPE & $\begin{array}{l}\text { NUMBER OF } \\
\text { SPECIMENS }\end{array}$ & ARTIFACT TYPE & $\begin{array}{l}\text { NUMBER OF } \\
\text { SPECIMENS }\end{array}$ \\
\hline $\begin{array}{l}\text { Construction Items } \\
\text { Asphalt tile } \\
\text { Ceramic tile } \\
\text { Wire nails } \\
\text { Kitchen/Dining Items } \\
\text { Ceramics } \\
\text { Lead-glazed ware }\end{array}$ & $\begin{array}{r}1 \\
4 \\
12\end{array}$ & $\begin{array}{l}\text { Tin-glazed wares } \\
\text { Pueblo Polychrome } \\
\text { San Elizario Polychrome } \\
\text { Unglazed earthenware } \\
\text { Goliad } \\
\text { Stoneware bottle } \\
\text { Shell } \\
\text { Oyster }\end{array}$ & $\begin{array}{l}1 \\
1 \\
1 \\
1 \\
2\end{array}$ \\
\hline
\end{tabular}




\section{SUMMARY OF PHASE IV TESTING}

The excavations on the northeast corner of NCB 100 provided additional information. The excavation of Trench E provided a chance to examine the construction of an early stone-lined well. Locating an intact house foundation helped confirm the existence and size of the Salinas-Barrera house. For some reason, no trace was found in any of the trenches of 1986 or 1987 of the jacal of Mr. Salinas that preceded the stone house built by his daughter. Either the remains were too ephemeral to withstand the later demolition processes, or the same wall lines were utilized, obliterating traces of the jacal wall trenches.

The artifacts recovered, while interesting in their own right, cannot be traced with any confidence to specific occupations of the lot due to the confused nature of the depositions. Specific artifacts and something of their origins are discussed in the following section.

\section{ARTIFACT ANALYSIS}

\section{METHODOLOGY}

All artifacts recovered during the various phases of this project were cleaned and cataloged as the field work was finished. Each lot was sorted into individual artifact types, and each artifact was labeled with its site number and provenience within the site. The artifacts were counted, and the totals were then entered on a standard CAR analysis sheet for historic sites.

The order in which categories are listed on this analysis sheet aids in the understanding of a site's contents, and helps to insure accuracy of identifications when more than one laboratory worker is involved in the cataloging process. By grouping articles of similar use or origin together, the process of analysis and the comparison of one site with another are also made simpler and more accurate.

\section{CERAMICS}

Ceramics are considered the most useful artifact category for dating, as well as for other types of analysis based on vessel type and country of origin. Sherds are sorted by paste and surface treatment, which also frequently indicate their approximate date and where they were made. The technology of their manufacture is also often important in separating types. Within the basic categories, sherds are then sorted according to specific types. The extent of this sorting depends somewhat upon the purpose for which the analysis is being done.

Unglazed sherds encountered in the San Antonio area include bone-tempered hand-built wares nearly identical to those found on prehistoric sites in south Texas. Called Goliad ware because of its first recognition at the mission at Goliad (Mounger 1959), this appears to be a continuation into historic times of the type of pottery made and used by the Indians who were taken into the missions in the San Antonio River valley. It often makes up as much as $75 \%$ of the total sherd count on 18 th-century sites.

Another type of unglazed ware is buff colored and wheel made, occasionally bearing red painted designs. Ivey and Fox (1981:31) have suggested that this be called Valero ware after Mission San Antonio de Valero where it was first noted and described. Ivey (Ivey and Fox 1982:33) has proposed a date range from ca. 1730 to 1760 for its popularity in San Antonio.

Burnished wares with red or tan paste represent the survival in Mexico of preconquest ceramic technologies. A few of these sherds are present on all 18th-century Spanish sites in Texas. Lead-glazed utility wares brought from Mexico include a thin, mold-made redware (Fig. 13,a) and heavier, sandy paste wheel-made wares with yellow or green glaze. Although the former type continued to be made in Mexico well into the 19th century, it drops out of San Antonio inventories after ca. 1836. 


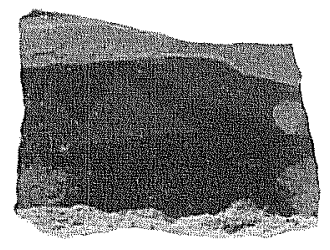

a

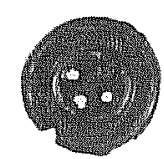

e

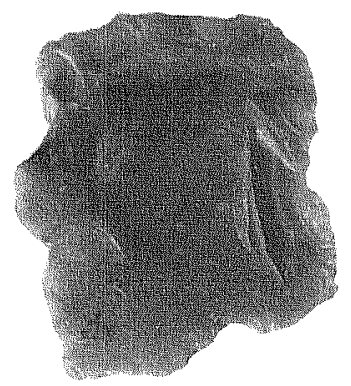

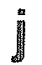

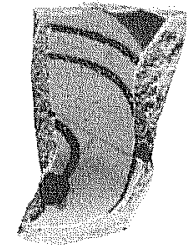

b

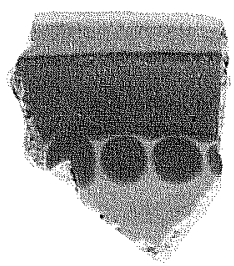

c
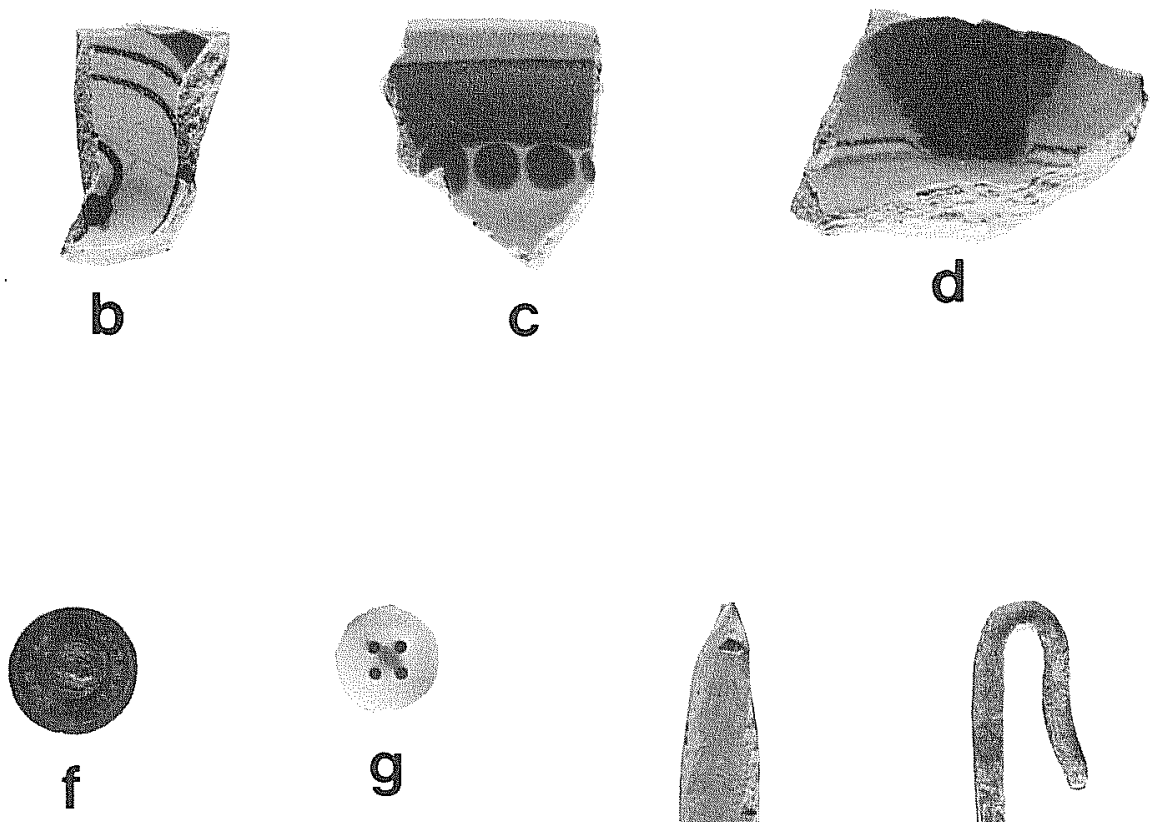

9
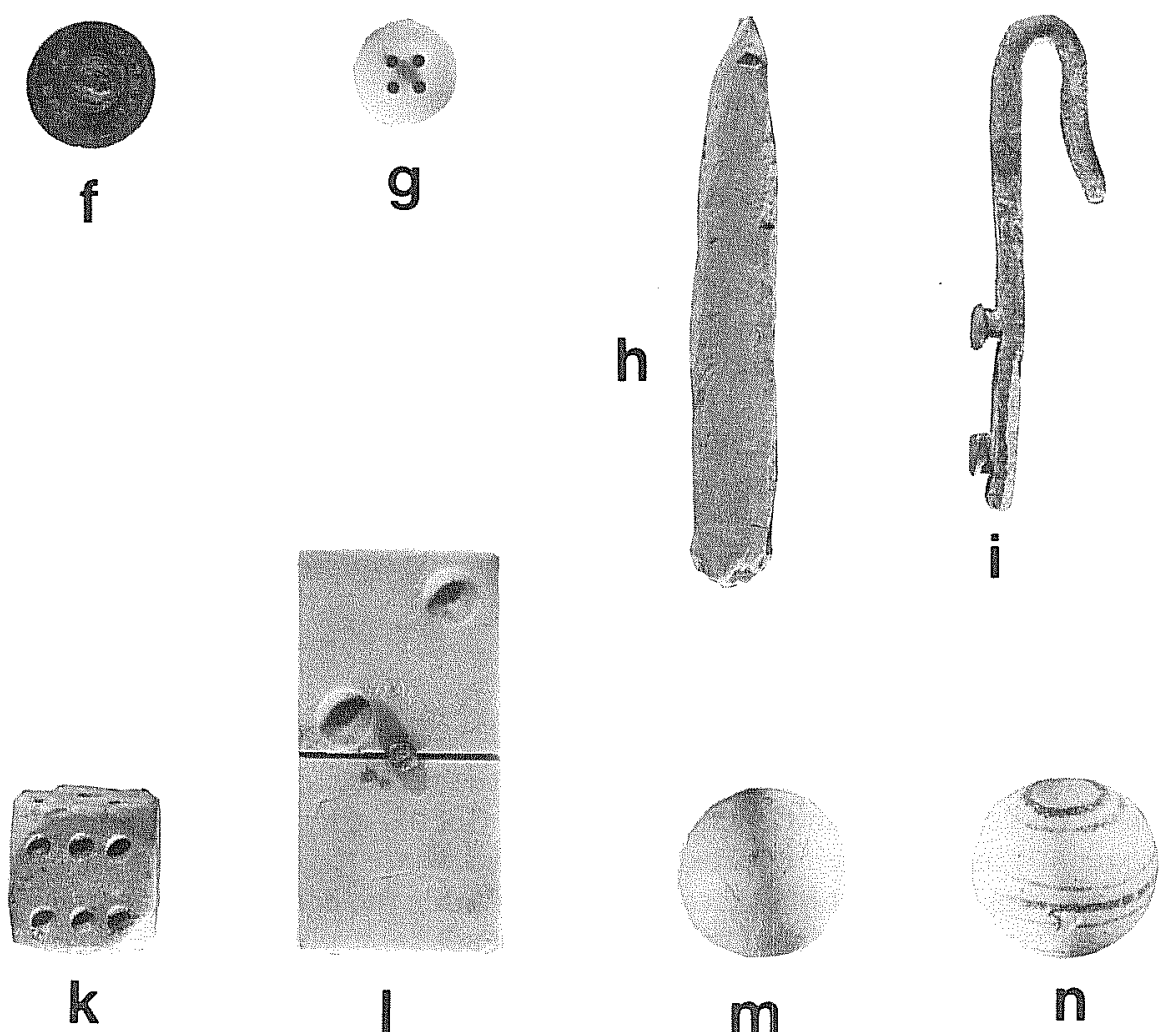

m

Figure 13. 18th-Century Ceramics and Other Artifacts. (All artifacts are actual size.) a, lead-glazed redware, 41 BX 647, Trench D, East, 80-90 cm; b, Puebla Polychrome majolica, 41 BX 647, Trench F; c, San Elizario majolica , 41 BX 647, Trench E; d, Monterey Polychrome, 41 BX 647, Trench E well casing; e, stamped metal button, $41 \mathrm{BX} 647$, Trench D East, 50-60 cm; f, brass button, IMPERIAL TRIPLE GILT, 41 BX 647, Trench D East, 70-80 cm; g, white glass button, $41 \mathrm{BX} \mathrm{335;} \mathrm{h,} \mathrm{bone} \mathrm{tool,} \mathrm{function} \mathrm{unknown,} 41 \mathrm{BX} 647$, Trench D East, 70-80 cm; i, brass military adjustment hook, $41 \mathrm{BX} 335$; j, chert tool, $41 \mathrm{BX} 647$, Trench D East, $60-70$ $\mathrm{cm}$; $\mathrm{k}$, bone die, $41 \mathrm{BX} 647$, Trench $\mathrm{D}$ East, $60-70 \mathrm{~cm}$; l, ivory domino face, $41 \mathrm{BX} \mathrm{335;} \mathrm{m}$, clay marble, $41 \mathrm{BX} 335$; $\mathrm{n}$, stone marble, red and green painted stripes, $41 \mathrm{BX} 336$. 
Tin-enameled earthenwares from Mexico, called majolica, represent ca. 10 to $15 \%$ of the ceramics on 18 th-century sites. These can be helpful in dating deposits, since most of the decorative designs changed through time. It has therefore been useful for analysis to breakdown tin-glazed types into individual, datable patterns as follows:

Puebla Polychrome (Fig. 13,b) - ca. 1650 to 1725 (Snow 1965:32)

Blue-on-White - not currently datable

Huejotzingo - $1700+$ (Gerald 1968:43)

Wavy Edged - ca. $1770+$ (Barnes 1972:11)

San Elizario Polychrome (Fig. 13,c) - 1750 to 1850 (Gerald 1968)

Aranama Polychrome - ca. 1750 to 1850

San Diego Polychrome - 1770 to 1800 (May 1972:35)

Monterey Polychrome (Fig. 13,d) - 1790 to 1830 (May 1972:36)

Tumacacori Polychrome - 1780 to 1860 (Barnes 1972:11)

Guanajuato Polychrome - post-1820 (Lister and Lister 1975:42)

French-made tin-glazed ware, called faience, is also present in very small amounts on San Antonio sites. Types found locally date primarily to the mid-18th century.

In the early 19th century, English-made white earthenwares entered Texas through coastal ports and came overland through east Texas with settlers from the United States. Most of these whitewares were decorated in various ways in bright colors which were appealing to potential purchasers, both Anglo-Americans who were already accustomed to them and to residents of Spanish/Mexican background as a successor to their tin-glazed dishes. The latter were becoming hard to obtain as the cheaply made English wares flooded world markets and forced the Mexican factories out of business. Most of the decorated wares were imported between 1830 and 1850 and are identified by the method in which they are decorated: banded slip, hand painted, transfer, shell edged, sponged, etc. (Fig. 14,c-1). A few of these decorative techniques continued to be popular into the last quarter of the 19th century, but the colors and designs on the later versions (Fig. $14, a, b)$ are different enough to allow the experienced analyst to recognize them.

After 1850, the fashion changed, and housewives preferred plain or molded whitewares and ironstones. Since the cream colored, white, and ironstone wares are nearly impossible to separate into individual types on the basis of color or paste, they are grouped together on the inventory sheet. A noticeable increase in the proportion of undecorated whitewares is an indication of the approach of the $1860 \mathrm{~s}$ in site deposits.

The last half of the 19th century saw the introduction in Texas of a number of other types of ceramics. Yellowbodied wares decorated in mottled browns and/or greens made into kitchen wares such as mixing bowls and pitchers became widely available through mail-order firms. Fine porcelain plates, tea cups, and saucers were used in the wealthier households. A few items of painted or gold decorated porcelain were used for special occasions.

For kitchen and dairy use, heavy stoneware vessels were made locally in Texas after the mid-19th century. The type of glaze used to coat these vessels and their general shape help to date them. At the same time, stoneware bottles made in Scotland and Europe and filled with popular drinks such as ginger beer and ale were unloaded by the thousands at the coastal ports and shipped inland for sale by merchants in the larger towns.

A new, inexpensive form of decorating chinaware became popular around the turn of the 20th century. Decalcomania designs applied over the glaze are an indication of this time period. Slightly later, it became fashionable to have sets of tableware glazed in plain colors such as light green, pink, and yellow with no other decoration. A few pieces of these ceramics are often found in early 20 th-century deposits.

Technological details of glass container analysis can be helpful in backing up or confirming dates within the late 19th and early 20th centuries (Kendrick 1967:19-24). However, this type of analysis is of little help in dealing with the 18th century, since very little glass survives in the sites of this period other than hand-blown wine bottles which are nearly impossible to date. The tremendous increase in glass container production in 
Figure 14. 19th-Century Ceramics. (All artifacts are actual size.)

a, late 19th-century painted ware, $41 \mathrm{BX} 337$;

b, late 19th-century transferware pattern, $41 \mathrm{BX} 647$, Trench E;

c, banded slipware, $41 \mathrm{BX} 647$, Trench D East, $80-90 \mathrm{~cm}$;

d, blue shell-edged ware, $41 \mathrm{BX} 647$, Trench D East, $80-90 \mathrm{~cm}$;

$\mathrm{e}$ blue and red hand-painted ware, $41 \mathrm{BX} 335$;

f, black and green hand-painted ware, $41 \mathrm{BX} 336$;

g, blue hand-painted ware, 41 BX 647, Trench D East;

h, green transferware pattern, 41 BX 647, Trench E, Level 3;

i, red transferware pattern, $41 \mathrm{BX} 647$, Trench D East, $60-70 \mathrm{~cm}$;

j, blue transferware pattern, $41 \mathrm{BX} 647$, Trench $\mathrm{E}$;

k, black transferware pattern, Davenport impressed mark, 41 BX 647, Trench E;

1, blue spongeware, 41 BX 647, Trench E, Level 3. 

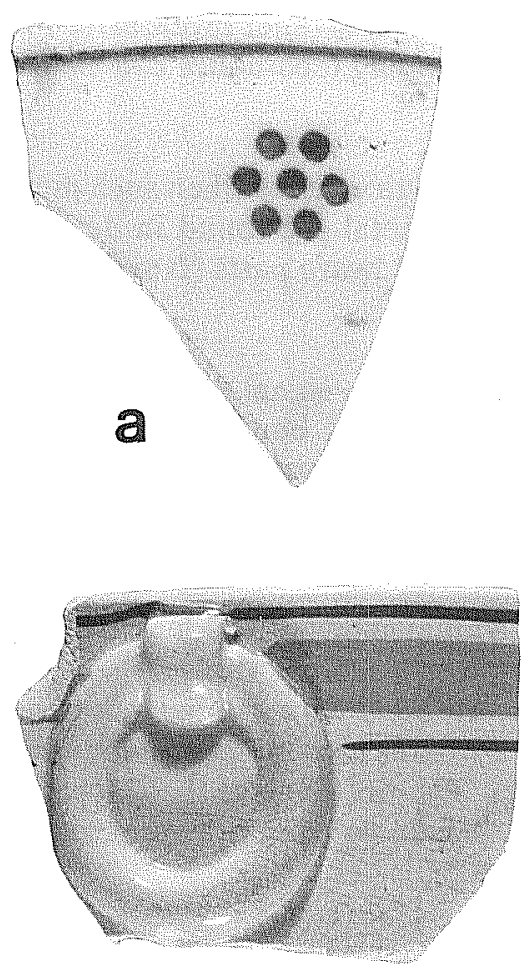

e

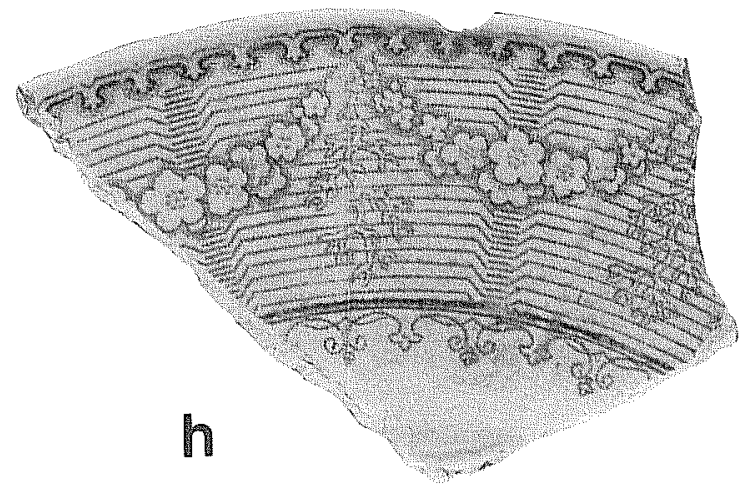

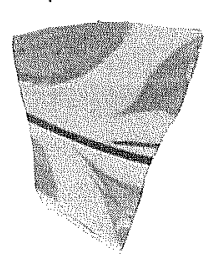

f

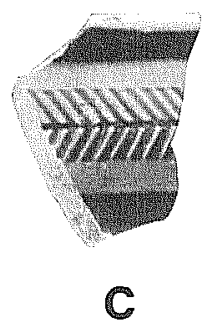

b
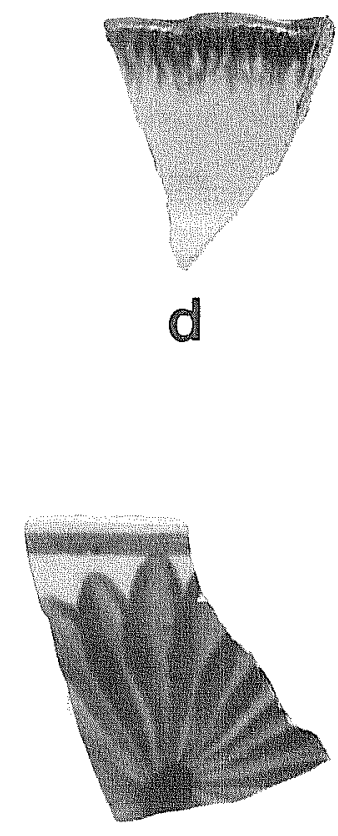

9
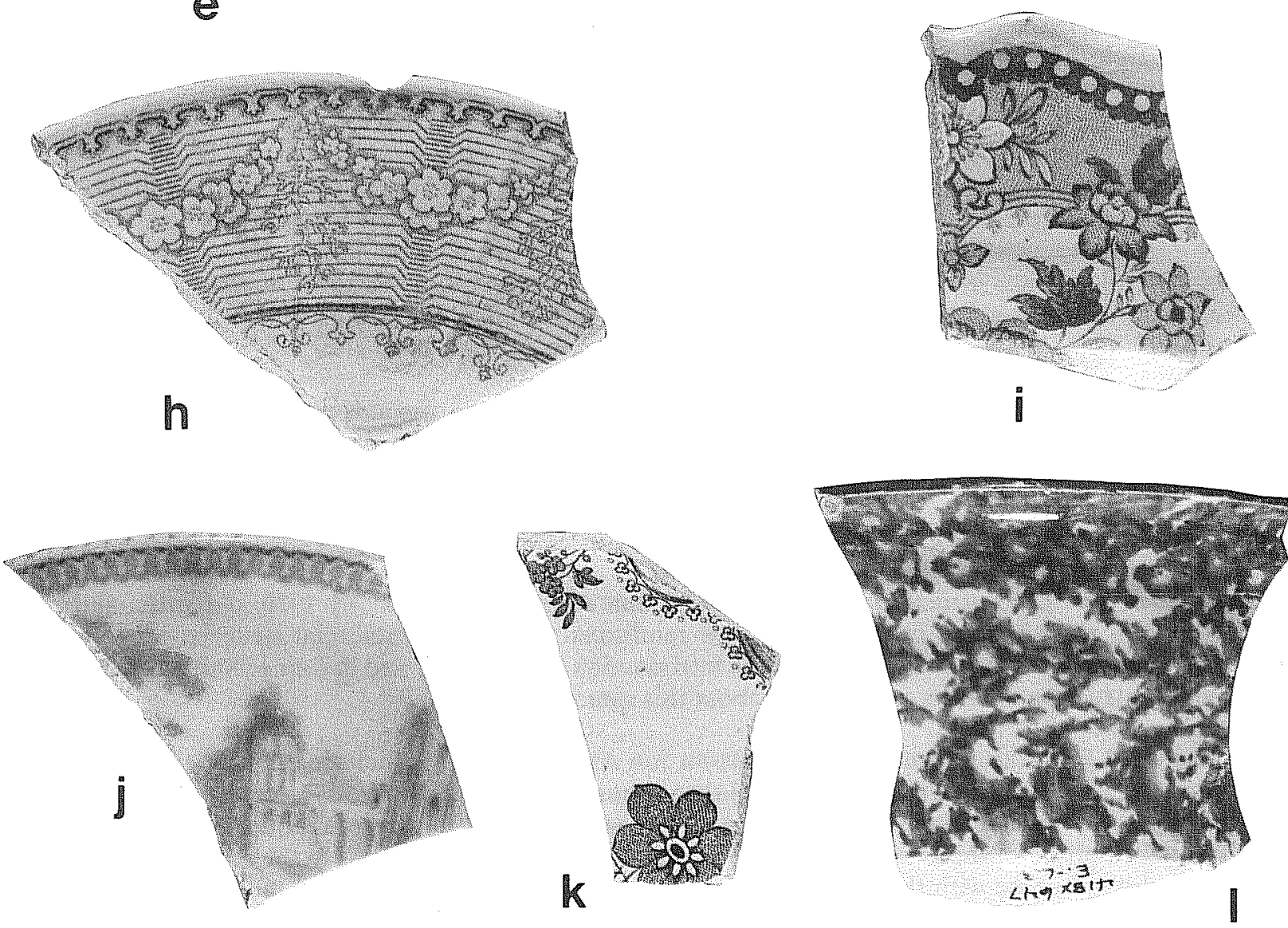
the last part of the 19th century and early 20th century is a highly visible factor in artifact inventories and can help to date such a collection in a general way. The evolution of bottle capping techniques can also be helpful in dating strata at the turn of the 19 th century.

The presence of metal scrap and tin cans generally signals the approach of the 20th century when such metal objects became prevalent. In 18th-century sites, fragments of thin, cuprous metal are found in deposits related to house sites, and iron is scarce except for horse trappings and a few hardware parts (Ivey and Fox 1982:40).

Bone and shell reflect dietary habits, and the comparative amounts in features often signal the presence or absence of household garbage versus other types of trash disposal. Analysis of bone can also yield information about butchering techniques used in various time periods and by various population groups, as demonstrated in the next section of this report. On the whole, collections used for such analysis must be carefully screened as in the acequia (41 BX 337) and Trench D excavations.

The isolation of clothing and personal items allows examination of the individual habits of residents of a site and gives some idea of who was there. For instance, children's clothing items such as the very smallest buttons, metal shoe reinforcements, marbles (Fig. 13,g,m,n), doll parts, etc., indicate a family situation present. Sewing implements such as scissors, needles, and pins, suggest a woman's presence, as do pieces of jewelry and fancy buttons such as would be used on women's clothing. The presence of these types of items can confirm a residential versus a commercial occupation on a site. While no one of them alone is a reliable indicator, a combination of such items gives confirmation.

Grouping the barn and workshop items together allows examination of activities on a site. The types of tools and their methods of manufacture, and other various kinds of hardware items, can often help to date a deposit. The presence of hand-forged versus machine-made articles in this collection would, for example, suggest an 18th-century to mid-19th-century date, while machine-made items, especially those that bear patent dates, are not only datable but also probably can be identified in catalogs of this period which are readily available.

The examination of construction materials helps in determination of the type of structure on the site, how it was built, and often even the color of the paint on the walls. Here again, individual items can be dated, at least within broad parameters, to confirm estimated dating from other categories of artifacts. Nail technology evolved from hand-wrought in the 18th century to cut nails in the mid-19th century to wire nails after about 1890 (Nelson 1968). Window glass, although not a reliable indicator, generally became thicker in the late 19th century and was practically nonexistent in San Antonio until after 1850.

Spanish brick is readily separated from the 19 th-century varieties by its dimensions and its low firing. Mortar and plaster contents changed through time. Spanish/Mexican and early Anglo/German builders in San Antonio used a soft sand and lime mortar made with homemade lime that often contained fragments of charcoal. Commercially made cement came into use in the last quarter of the 19th century, along with kiln-fired commercially made brick.

Reinforced concrete construction came into use in San Antonio ca. 1900. By 1920, old wood and stone buildings were rapidly being replaced with new reinforced concrete commercial structures that had the added advantage of being more fireproof. The introduction of electricity and indoor plumbing added a new group of construction artifacts to the list at about this same time.

When the CAR first started working on downtown San Antonio sites, the inclusion in historic sites of chert flakes and occasional chert artifacts (Fig. 13,j) that appeared to have been used for cutting or scraping was thought to be merely a reminder that prehistoric Indians also lived in the general vicinity. However, the persistent occurrence of these artifacts in 18th-century contexts has brought us to the realization that chert utilization did not cease with the indoctrination of the Indian population into the missions (Fox 1977:16). The frequent presence of these sorts of objects in 18th-century downtown sites suggests that the techniques of chert working had not been abandoned at the close of the 18th century, as previously thought. 


\section{BUTCHERING TECHNIQUES}

Among the artifacts recovered during archaeological testing and excavation of NCB 100 in downtown San Antonio was a moderate quantity of animal bone. Some of these bones or bone fragments were from domestic animals and bore butchering marks or were the final result of butchering activities. This report will be concerned with a sampling of these bones and bone fragments from the acequia fill (41 BX 377) and from a controlled test excavation in the back yard of the Salinas-Barrera house (41 BX 647).

Recovered faunal material was first washed and labeled according to site number, unit, and level. The identifiable bones were then sorted by species. Only bones and bone fragments from domesticated animals commonly utilized as food sources such as cow (Bos taurus), pig (Sus scrofa), and chicken (Gallus gallus) were considered for this report. Identification was made using the faunal collection at the CAR-UTSA.

All selected bones and bone fragments were examined for evidence of human modification, such as butcher marks or the spiral fractures associated with intentional splitting (Gilbert 1980). Butcher marks were noted as to type of mark and location of mark on the bone or bone fragment. Local area butchers were consulted for additional information on butchering techniques and which cuts of meat were represented by the bone fragments. The sample was not considered suitable for estimating minimal number of individuals.

\section{BUTCHERING MARKS AND THE BUTCHERING PROCESS}

Butcher marks consisted of axe, hatchet, or cleaver/large knife cuts which were visible as deep wedge-shaped cuts, sometimes causing local crushing of the bone. Saw marks were easily recognized as an extensive smooth or polished surface with visible striations. Gust (1983) has compared the saw marks left by hand saws and powered bandsaws. The striations left by hand saws appear more irregular and less smooth than those produced by powered bandsaws.

Examination of the marks produced by butchering allows some inferences to be made as to the location and type of butchering being done, i.e., home versus commercial. Bones that are sawn on a powered bandsaw most likely represent cuts of meat which originated in a commercial butchering establishment. On the other hand, bones which demonstrate marks produced by a large-toothed hand saw or chop marks may indicate home butchering or secondary reduction of meat carcasses at home. Absence of powered bandsaw marks on bones may also indicate that butchering occurred before the use of powered saws by commercial butchers became common.

It is common practice when utilizing powered saws to split a beef or hog carcass, sawing the vertebrae longitudinally in such a manner that the dorsal spines are evenly split. When a carcass is hand sawn or cleaved/chopped in half, usually the dorsal spines are left intact on one side or the other. A powered saw is generally utilized to commercially reduce ribs. Before the advent of powered saws, butchers reduced ribs by partial cleavage and final breaking of the ribs.

In addition to butcher marks, an attempt to identify the anatomical location for the bone or bone fragments was considered. Was it derived from the front or hindquarters of the animal? Did the bone represent one of the more desirable expensive cuts of meat, or did it represent a cheaper, less desirable portion of the animal? The forequarter cuts are often less expensive, and cuts from lower on the extremities are often only good for marrow or soup bones. A large number of bovine feet, skull, and tail bones would suggest home slaughtering and butchering as opposed to a meat market economy. Clonts (1983) maintains that from this type of information, inferences about the economic status of a household or neighborhood may be derived. A higher percentage of choice meat cuts as opposed to soup bones and less desirable cuts would suggest a greater level of affluence. 


\section{THE ACEQUIA (41 BX 337)}

A bone was recovered in 1978 from a $21 / 2$-foot-section of the acequia that was excavated to a bottom depth of five feet. Excavation was conducted in four distinct levels. The fill is thought to date from the latter part of the 19 th century to the very early 20 th century when the acequia was completely filled in and its use discontinued.

Preservation of the bone from the acequia is generally good, though much of the bone is so fragmented that species identification is difficult to impossible. There are very few fragments of bone that show evidence of burning. Little difference can be detected in the frequency with which particular bone elements occurred between the four levels. The frequency of cow to pig bone is approximately 3:1. Chicken bones (total of 5) were infrequent in all levels.

Identifiable cow bones and fragments (total of 71 ) include 20 steak bones and six bones derived from roasts, together with 12 vertebrae and 19 rib fragments. There are also 14 hind or foreleg fragments that could be categorized as soup or marrow bones. Excluding rib fragments, the majority of the bones and fragments (total of 36 ) originate from the hindquarters of the carcass.

Identifiable pig bones and fragments (total of 22) include four rib chops and five fragments of rib, together with nine arm steak bones and four ham bones. There appears to be an equal representation between fore and hindquarter cuts of meat.

Only one fragment of a cow rib shows evidence of having been chopped. The rest of the rib fragments from the sample have been sawn on a bandsaw. Many of these rib fragments have fine knife marks where meat was separated from the bone, probably at the time of consumption. All of the soup and marrow bones have fine knife marks or chop marks where meat was detached from the bone. The steak bones were uniform in thickness and sawn on a bandsaw. Vertebral fragments were split longitudinally through the center of the dorsal spines utilizing a bandsaw.

\section{THE SALINAS-BARRERA HOUSE (41 BX 647)}

A bone was recovered in 1987 from a controlled excavation in the eastern end of Test Trench D. Excavation was conducted in 10-inch levels, and the sample represents the bone recovered from levels extending from 40 inches to 110 inches in depth. All material was screened through $1 / 4$-inch screen. This material was associated with a late 18 th-century to early 19 th-century dwelling.

Preservation of the bones and bone fragments is generally good, though much of the sample is so badly fragmented that species identification is impossible. The quantity of identifiable butchered bone recovered between 40 and 60 inches in depth is rather sparse (total of 8 ). Between 60 and 110 inches in depth, the amount of identifiable butchered bone recovered is greater (total of 79). The quantity and type of bone per level are relatively uniform from 60 to 110 inches. Accordingly, the bone by level will not be given in this report, but all five levels will be considered as one.

Indentifiable butchered bone from 40 to 60 inches in depth consisted of three fragments of cow rib and a supraorbital fragment from a cow skull, a pug cuboid, and three fragments of leg bone. All fragments have knife or chop marks.

Between 60 and 110 inches in depth, identifiable butchered cow bones (total of 53) include three ankle or foot bones, seven foreleg fragments, and four hind leg fragments. Other cow bones displaying butcher marks are 17 rib fragments, 10 vertebral fragments, eight pelvic or scapula fragments, and a round steak bone. Five teeth or fragments of teeth that do not have butchering marks are probably related to some form of butchering. The only cow bone that has saw marks is the round steak bone; the majority of the others have been chopped or have knife marks. 
Identifiable butchered pig bones (total of 21) include eight rib fragments, two cuboids, a fragment of mandible and vertebrae, and nine bones from the forefeet. None of the pig bones have been sawn, but knife and chop marks are present. Five bones identifiable as being chicken bones were also recovered.

Cow bones outnumbered pig bones by an approximate ratio of $2: 1$. Half of the pig bones were derived from the ankle or below. All of the rib fragments of both cow and pig had been reduced by chopping part way through the rib with a large knife or cleaver and then breaking through the remainder. Winkler (1986) has noted that the same method of reduction was utilized by the early to mid-19th-century inhabitants of La Villita in San Antonio.

\section{DISCUSSION}

The bone samples are not large enough to enable one to draw definite conclusions about the butchering practices of 19th-century San Antonio. What they do offer is some suggestions about the preferred meats and techniques for preparing that meat.

The sample of bone from 41 BX 337 is not unlike that reported by Harrison (1987) from Guenther's Upper Mill near downtown San Antonio. The sample most likely represents the kitchen refuse of a moderately affluent household at the turn of the century as evidenced by the number of steak bones and cuts from the hindquarters: The meat was procured from a commercial butchering establishment as evidenced by the large number of bones sawn on a power saw. Beef was the much preferred meat as opposed to pork or chicken.

In contrast, the bone sample from $41 \mathrm{BX} 647$ is almost devoid of sawn bone. Partially, this reflects an earlier time before the advent of powered saws. It could also suggest domestic butchering or secondary reduction of a carcass or partial carcass at home. The skull and lower leg fragments from both cow and pig should tend to support domestic butchering. In addition, the sample from $41 \mathrm{BX} 647$ by the absence of steak bones may indicate an ethnic preference for different cuts of meat from the traditional Anglo-American. Clonts (1983) has remarked on ethnic differences in butchering practices in mid-19th-century Tucson, Arizona, which could also apply to San Antonio, Texas. The majority of the bones from 41 BX 647 are also from what would be considered less than choice cuts of meat. This would suggest that the household with which they were associated was not affluent. Beef bones and fragments outnumbered pork, as in the 41 BX 337 sample, indicating that beef was the preferred meat. Chicken bones were poorly represented in both samples.

The bones and fragments of bone in the two recovered samples most likely represent deposition of domestic cooking refuse. Species frequency suggests that beef was the meat of choice followed by pork. Chicken bones were poorly represented. No bones or bone fragments were identified as being the remains of sheep or goat. This does not mean that sheep and goat were not consumed, only that none of the bones or bone fragments were identifiable as such.

\section{CONCLUSIONS AND RECOMMENDATIONS}

At the south end of NCB 100, site 41 BX 334 (223 West Nueva Street) is recommended for nomination to the National Register of Historic Places and as a State Archeological Landmark. This recommendation is based on the fact that it was the residence of a well-known person, and it appears that the site has the potential to contain much additional information on architecture and living habits of San Antonians from the late 19th century through the early 20th century. Site 41 BX 335 (225 West Nueva Street) is also recommended for nomination to the National Register and to become a State Archeological Landmark because it appears to contain architectural and artifactual data from 1850 to 1900 . Also, the good state of preservation of the kitchen/dwelling in the back yard suggests that more can be learned about the evolution of this structure and its possible final use in connection with a blacksmith shop. Somewhere in the general area there should be trash disposal pits and there may be traces of a blacksmith shop.

As long as these two sites are sealed beneath asphalt pavement, they are not endangered. If for any reason the county decides to disturb this area, archaeological investigations should be undertaken. 
The acequia (41 BX 337) has obviously been badly disturbed by stone robbing and later construction. However, a section at the north end of the block appears to be relatively intact and will be restored as a part of the landscape plan for the new building. We recommend that this section also be nominated to the National Register and as a State Archeological Landmark.

\section{REFERENCES CITED}

Anonymous

1907 A Twentieth Century History of Southwest Texas. Vol. II. The Lewis Publishing Company, Chicago.

Atterbury, P. J.

1979 European Pottery and Porcelain. The Main Street Press, Clinton, New Jersey.

Barnes, M. R.

1972 Majolica of the Santa Cruz Valley, Arizona. In Mexican Majolica in Northern New Spain, by M. R. Barnes and R. V. May:3-23. Pacific Coast Archaeological Society Occasional Paper 2.

Bexar County, Texas

Bexar County Archives (BCA)

List of the Individuals of the Ayuntamienta of the Villa of San Fernando and the Residents That Voluntarily Have Contributed to the Materials for the New Cuartel, By the Order of the Commandant General of the Internal Province of New Spain 1793; Census of Villa of San Fernando 1797; List of the Families in the Villa of San Fernando and the Pres[idi]o of Bexar 1804; Rebel Properties 1813; San Fernando Burial Records (SFBR); San Fernando Marriage Records (SFMR); San Fernando Death Records (SFDR); Spanish Archives (SA); Wills and Estates (WE); Deed Records (DR); Probate Records (PR). Office of the County Clerk, Bexar County Courthouse, San Antonio, Texas.

Campbell, C. A. R.

1925 Bats, Mosquitoes and Dollars. The Stratford Company, Boston.

Chabot, F. C.

1937 With the Makers of San Antonio. Privately printed, San Antonio.

City Directories

1877- Microfilm located at the Center for Archaeological Research, The University of Texas at 1928 San Antonio. 
Clark, J. W., Jr. and A. M. Juarez

1986 Urban Archaeology: A Culture History of a Mexican-American Barrio in Laredo, Webb County, Texas. Vol. 1. Texas State Department of Highways and Public Transportation, Highway Design Division, Publications in Archaeology, Report 31.

Clonts, J. B.

1983 Some Long Overdue Thoughts on Faunal Analysis. In Forgotten Places and Things: Archaeological Perspectives on American History, edited by A. E. Ward: 341-348. Center for Anthropological Studies, Albuquerque, New Mexico.

Eaton, J. D.

1980 Excavations at the Alamo Shrine (Mission San Antonio de Valero). Center for Archaeological Research, The University of Texas at San Antonio, Special Report 10.

n.d. Archaeological Investigations at San Fernando Cathedral, San Antonio, Texas. Manuscript on file at the Center for Archaeological Research, The University of Texas at San Antonio.

Ellis, W. B.

1986 Preliminary Archaeological Assessment of the Northeast Parking Lot Area (Phase III) Site of the New Bexar County Justice Center, San Antonio, Texas. Draft report on file at the Center for Archaeological Research, The University of Texas at San Antonio.

Fehrenbach, T. R.

1978 The San Antonio Story. Continental Heritage, Inc., Tulsa, Oklahoma.

Folan, W. J., I. W. Cox, A. A. Fox, and G. M. Hinojosa

1986 Laredo, Texas: A Gateway Community on the Texas Borderlands. Archaeological and Historical Investigations for the Laredo City Toll Plaza. Center for Archaeological Research, The University of Texas at San Antonio, Archaeological Survey Report 116.

Fox, A. A.

1977 The Archaeology and History of the Spanish Governor's Palace Park. Center for Archaeological Research, The University of Texas at San Antonio, Archaeological Survey Report 31.

1978a Preliminary Archaeological Assessment of South Parking Lot Area (Phase I), Site of Courthouse Annex, San Antonio, Texas. Letter report to Bexar County Commissioners Court, October.

1978b Archaeological Investigations of Portions of the San Pedro and Alazan Acequias in San Antonio, Texas. Center for Archaeological Research, The University of Texas at San Antonio, Archaeological Survey Report 49.

1986 Ceramics. In La Villita Earthworks (41 BX 677): San Antonio, Texas. A Preliminary Report of Investigations of Mexican Siege Works at the Battle of the Alamo, assembled by J. H. Labadie:107-127. Center for Archaeological Research, The University of Texas at San Antonio, Archaeological Survey Report 159. 
Fox, A. A., F. A. Bass, Jr., and T. R. Hester

1976 The Archaeology and History of Alamo Plaza. Center for Archaeological Research, The University of Texas at San Antonio, Archaeological Survey Report 16.

Fox, A. A. and T. R. Hester

1976 Archaeological Test Excavations at Mission San Francisco de la Espada. Center for Archaeological Research, The University of Texas at San Antonio, Archaeological Survey Report 22.

Fox, A. A. and J. E. Ivey

n.d. Archaeological and Historical Investigations at Alamo Historical Park, San Antonio, Texas. Center for Archaeological Research, The University of Texas at San Antonio, Archaeological Survey Report 120. Manuscript on file.

Fox, D. E.

1983 . Traces of Texas History. Corona Publishing Company, San Antonio.

Fox, D. E., D. Scurlock, and J. W. Clark, Jr.

1977 Archeological Excavations at San Fernando Cathedral, San Antonio, Texas: A Preliminary Report. Office of the State Archeologist, Special Report 22.

Gerald, R. E.

1968 Spanish Presidios of the Late Eighteenth Century in Northern New Spain. Museum of New Mexico Research Records 7. Museum of New Mexico Press, Santa Fe.

Gilbert, B. M.

1980 Mammalian Osteology. Privately printed, Laramie, Wyoming.

Giraud, F.

1849 Plat of Salinas property. Plat book. Bexar County Archives, Bexar County Courthouse, San Antonio, Texas.

Godden, G. A.

1964 Encyclopaedia of British Pottery and Porcelain Marks. Bonanza Books, New York.

1971 The Illustrated Guide to Mason's Patent Ironstone China and Related Wares. Praeger Publishers, New York.

Greer, J. W.

1967 A Description of the Stratigraphy, Features and Artifacts from an Archeological Excavation at the Alamo. State Building Commission Archeological Program, Report 3. 
Gust, C. M.

1983 Problems and Prospects in Nineteenth Century California Zooarchaeology. In Forgotten Places and Things: Archaeological Perspectives on American History, edited by A. E. Ward:341-348. Center for Anthropological Studies, Albuquerque, New Mexico.

Harrison, R. R.

1987 Faunal Analysis. In Archaeological Studies for the San Antonio Channel Improvement Project, Including Investigations at Guenther's Upper Mill (41 BX 343), by A. A. Fox, L. M. Flynn, and I. W. Cox:103-106. Centerfor Archaeological Research, The University of Texas at San Antonio, Archaeological Survey Report 136.

Hatcher, M. A., translator and editor

1935 Letters of Antonio Martinez, the Last Spanish Governor of Texas, 1817-1822. Southwestern Historical Quarterly XXXIX:66-72, 139-147, 327-332.

Ivey, J. E. and A. A. Fox

1981 Archaeological Survey and Testing at Rancho de las Cabras, Wilson County, Texas. Center for Archaeological Research, The University of Texas at San Antonio, Archaeological Survey Report 104.

1982 Archaeological Investigations at Mission Concepción and Mission Parkway. Center for Archaeological Research, The University of Texas at San Antonio, Archaeological Survey Report 114. Manuscript on file.

James, V. L.

1938 Frontier and Pioneer Recollections of Early Days in San Antonio and West Texas. Artes Graficas Press, San Antonio.

Kendrick, G.

1967 Bottle Fragments Betray Age of Historical Sites. El Palacio 74(2):19-24.

Koch, A.

1873 Bird's Eye View of the City of San Antonio, Bexar County, Texas, 1873. In the San Antonio Museum Collection. Published by R. H. Holland.

Labadie, J. H., assembler

1986 La Villita Earthworks (41 BX 677): San Antonio, Texas. A Preliminary Report of Investigations of Mexican Siege Works at the Battle of the Alamo. Center for Archaeological Research, The University of Texas at San Antonio, Archaeological Survey Report 159.

Lister, F. C. and R. H. Lister

1975 Non-Indian Ceramics from the Mexico City Subway. El Palacio 81:25-48. 
May, R. V.

1972 An Evaluation of Mexican Majolica in Alta California, Employing Preliminary Data from the San Diego Presidio. In Mexican Majolica in Northern New Spain, by M. R. Barnes and R. V. May:25-50. Pacific Coast Archaeological Society Occasional Paper 2.

Mounger, M. A.

1959 Mission Espiritu Santo of Coastal Texas: An Example of Historic Site Archeology. Masters thesis, The University of Texas at Austin.

Nelson, L. H.

1968 Nail Chronology As An Aid to Dating Old Buildings. American Association for State and Local History Technical Leaflet 48.

Pease, S. W.

n.d. Campbell, Dr. Charles A. R. In They Came to San Antonio, 1794-1865. Unpublished manuscript on file at the Daughters of the Republic of Texas Research Library, The Alamo, San Antonio.

Ramsay, J.

1976 American Potters and Pottery. Ars Ceramicas, Ltd., Ann Arbor, Michigan.

Sanborn Map and Publishing Company, Ltd.

Maps of San Antonio, Texas, 1885, 1888, 1896-1904, 1923, 1952. New York.

Schuetz, M. K.

1966 Historic Background of the Mission San Antonio de Valero. State Building Commission Archeological Program Report 1.

1968 The History and Archeology of Mission San Juan Capistrano, San Antonio, Texas. State Building Commission Archeological Program Report 10.

1970 Excavation of a Section of the Acequia Madre in Bexar County, Texas, and Archeological Investigations at Mission San José in April, 1968. Texas Historical Survey Committee, Archeological Report 19.

n.d. Archeological Investigations at Mission San Antonio de Valero, the Second Patio. Unpublished manuscript on file at the Office of the State Archeologist, Austin, Texas.

Snow, D. H.

1965 The Chronological Position of Mexican Majolica in the Southwest. El Palacio 72(1):25-35.

Steinfeldt, C.

1978 San Antonio Was: Seen Through a Magic Lantern. Views from the Slide Collection of Albert Steves, Sr. San Antonio Museum Association, San Antonio. 
Taylor, F. B., R. B. Hailey, and D. L. Richmond

1966 Soil Survey of Bexar County, Texas. United States Department of Agriculture, Soil Conservation Service, in cooperation with the Texas Agricultural Experiment Station, Series 1962(12).

Tunnell, C.

1966 A Description of Enameled Earthenware from an Archeological Excavation at Mission San Antonio de Valero (The Alamo). State Building Commission Archeological Program Report 2.

Winkler, A. J.

1986 Preliminary Analysis of Faunal Remains. In La Villita Earthworks (41 BX 677): San Antonio, Texas. A Preliminary Report of Investigations of Mexican Siege Works at the Battle of the Alamo, assembled by J. H. Labadie:128-139. Center for Archaeological Research, The University of Texas at San Antonio, Archaeological Survey Report 159. 


\title{
APPENDIX \\ MONITORING OF JUSTICE CENTER TUNNEL
}

\author{
I. Waynne Cox
}

\section{INTRODUCTION}

During June 21-25, 1988, the Center for Archaeological Research monitored the excavation of a trench for a tunnel across South Main Avenue that will provide a substreet walkway between the Bexar County Courthouse and the new Justice Center. The monitoring was done by I. Waynne Cox, Center research associate. The monitoring was done under Texas Antiquities Committee Permit No. 564.

\section{LOCATION AND BACKGROUND}

The Bexar County Courthouse is located on the south side of Main Plaza in downtown San Antonio, with the new Justice Center being constructed across South Main Avenue to the west (Fig. 15). The area is bounded on the north by Dolorosa Street, east by Soledad Street, west by South Flores Street, and south by West Nueva Street. The courthouse was constructed from 1891 to 1896, with modifications to the structure in 1914, 1925, 1963, 1970, and 1973. The new Justice Center site had a variety of buildings, residential and later commercial, that have been completely removed in advance of the new construction.

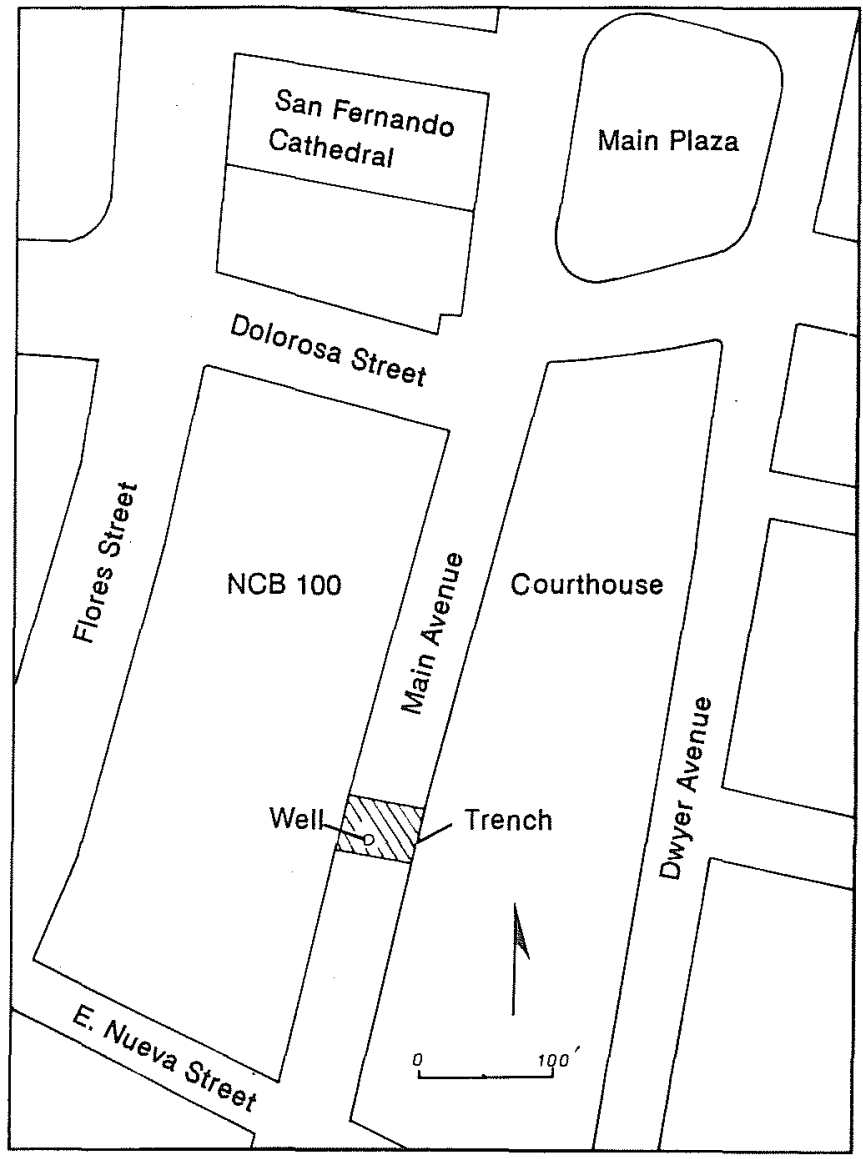

Figure 15. Location of Substreet Tunnel Trench. 
The area where the tunnel walkway is being constructed, now South Main Avenue, was a lot belonging to José Antonio de la Garza, youngest son of Leonardo Hipólito de la Garza (Chabot 1937:78). José Antonio constructed a two-story rock house on the lot facing onto Main Plaza (Plaza de las Islas). The lot originally extended from Dolorosa Street to West Nueva Street; the northern half of the lot was later designated as Lot 5, New City Block 100. In later years, the house, with modifications to the rear, became a hotel and boardinghouse. Bexar County purchased the lot in 1924 from George W. Burkitt, Jr., and Bess Burkitt Crane (DR Vol. 802:50, Vol. 979:411). In 1925-1927, when modifications were made to the west side of the courthouse, Main Avenue (formerly Acequia Street) was extended south of the Plaza. The street was further widened, from 47.5 feet to 60 feet, in November 1929 (DR Vol. 1161:120).

\section{THE EXCAVATIONS AND MONITORING}

On June 21, excavation began with a tracked backhoe. A concrete retaining wall was removed from the courthouse basement drive-through, and the soil was to be removed from street level to the depth of the basement floor. Excavations were completed on June 24 to a depth of approximately four feet, considered to be below the lowest cultural level. The asphalt roadbed was laid upon a 10 -inch bed of large limestone rubble. Under the limestones there was a 22-inch layer of dark fill. Adjacent to the courthouse, the layer contained broken, soft red brick with mortar and a few beef bones cut by a saw. Outside the disturbed area, the layer contained no artifacts. Below the dark fill was an underlying 20 -inch layer of brown soil grading into caliche which extended to the depth of the excavation.

On July 5, the archaeologist was notified by the contractor that a limestone structure had been exposed by deeper excavations. The structure was investigated and found to be a circular well built of cut limestone and filled with pieces of broken concrete slab. No artifacts were found in association with the well.

The well was located 35 feet west of the courthouse and had been situated on the extreme southern portion of Lot 5. Although the construction of the well could indicate some antiquity, the lack of any associated artifacts made dating impossible. The modern fill in the well indicates that it was probably filled at the time of the extension or widening of Main Avenue around 1925 to 1929.

\section{RECOMMENDATION}

As a result of monitoring the excavations for the substreet walkway, no significant cultural resources were noted that would require further study.

\section{REFERENCES CITED}

Bexar County, Texas

Deed Records (DR)

Office of the County Clerk, Bexar County Courthouse, San Antonio, Texas.

Chabot, F.

1937 With the Makers of San Antonio. Privately printed, San Antonio. 

